$203 e 58$

THE SOILS OF THE LOWER EASTERN SLOPES OF THE CAMEROON MOUNTAIN AND THEIR SUITABILITY FOR VARIOUS PERENNIAL CROPS 


\title{
THE SOILS OF THE LOWER EASTERN SLOPES OF THE CAMEROON MOUNTAIN AND THEIR SUITABILITY FOR VARIOUS PERENNIAL CROPS
}

\author{
PROEFSCHRIFT \\ TER VERKRUGING VAN DE GRAAD \\ VAN DOCTOR IN DE LANDBOUWKUNDE \\ OP GEZAG VAN DE RECTOR MAGNIFICUS, \\ IR. W. F. EUSVOOGEL, \\ hoOgleraAR IN DE HYDRAULICA, DE BEVLOEIING, \\ DE WEG- EN WATERBOUWKUNDE EN DE \\ BOSBOUWARCHITECTUUR, \\ TE VERDEDIGEN TEGEN DE BEDENKINGEN \\ VAN EEN COMMISSIE UIT DE SENAAT \\ VAN DE LANDBOUWHOGESCHOOL TE WAGENINGEN \\ OP WOENSDAG 26 APRIL 1961 TE 16 UUR \\ DOOR
}

H. N. HASSELO

H. VEENMAN EN ZONEN N.V. WAGENINGEN 1961 


\section{STELLINGEN}

\section{I}

De gouvernementswijk van Buea, de hoofdstad van Zuid Kameroen, is zeer ongunstig gelegen met het oog op het gevaar van verwoesting door vulkanische stromen.

Dit proefschrift

\section{II.}

Erosie van jong-vulkanische asgronden treedt op onder dezelfde omstandigheden als die, welke leiden tot de vorming van vulkanische modderstromen na asregens.

\section{III}

Het gevaar van erosie van de in cultuur gebrachte jong-vulkanische asgronden op de oostelijke hellingen van de Kameroen berg is groter dan de doorlatendheid van deze gronden en de geringe slibafvoer van de rivieren in dit gebied zouden doen vermoeden.

\section{IV}

Bij de waardering van gronden in gebieden met geprononceerde seizoenschommelingen voor de plantage-landbouw moet het bewortelingsvolume van een grond de doorslag geven.

Dit proefschrift

\section{V}

Aan het grote verloop van en het tekort aan plantagearbeiders in de dichtstbevolkte gebieden aan de oostkant van de Kameroen berg kan zonder verlies van netto plantage inkomsten tegemoet gekomen worden door de gronden met een bewortelingsdiepte van minder dan 60 tot $40 \mathrm{~cm}$ te bestemmen voor de verbouw van voedselgewassen door de arbeiders.

\section{VI}

Het onderzoek op het gebied van cultuur- en sanitaire maatregelen ter voorkoming en (of) bestrijding van ziekten in de plantagecultures van bananen en cacao is sterk verwaarloosd in vergelijking met dat van de chemische bestrijding.

\section{VII}

De bemestingsproeven van SPARNAAIJ met oliepalmen houden geen voldoende rechtvaardiging in voor zijn conclusie, dat stikstof een verlagend effect kan hebben op de ,sex ratio" van de bloeiwijze.

L. D. Sparnaalu, J. W. Afric. Inst. for Oil Palm Res., 3, 10, 1960 


\section{VIII}

Het streven om de bananencultuur meer winstgevend te maken door middel van cultuurmaatregelen, die erop gericht zijn om het hoofdoogstseizoen van de bananen te laten samenvallen met de periode van hoge zomerprijzen in Groot-Brittannië, heeft weinig kans op succes in Zuid Kameroen.

Annual Report B.B.R.D., Jamaica, 1957-1958

\section{IX}

Het door HARDY aangevoerde bewijsmateriaal voor zijn conclusie, dat een temperatuursverschil van meer dan $9^{\circ} \mathrm{C}$ per dag in de belangrijkste cacao producerende centra van de wereld, een afzonderlijke groeifactor is, is aanvechtbaar.

F. HARDY, CACAO, Inter-American Cacao Centre, Turrialba, 3, 17, 1958 


\section{VOOR WOORD/PREFACE}

De veelheid en verscheidenheid van probleem, die de onderzoeker in een zich snel ontplooiend onderontwikkeld land te beoordelen krijgt, hebben mij doen beseffen, hoeveel ik te danken heb aan U, Hoogleraren, Oud-Hoogleraren en Docenten aan de Landbouwhogeschool, die bijgedragen hebben tot mijn vorming als landbouwkundige. Dit werk was uiteraard niet gericht op het schrijven van een proefschrift. Het stemt mij daarom tot grote erkentelijkheid, dat $U$, Hooggeleerde EDELMAN, mij hierin de weg hebt gewezen, en door Uw belangstelling, medewerking en critiek de voltooiing van dit proefschrift hebt mogelijk gemaakt.

Uw colleges en practica, Hooggeleerde ScHufFelen, hebben de basis gelegd voor de bewerking van de gegevens, vermeld in hoofdstuk 5 . Het is mij een behoefte $U$ op deze plaats hiervoor en voor Uw waardevolle opmerkingen, gemaakt bij het doorlezen van dit hoofdstuk, te bedanken.

Ludwig A. Sanders (c.i. Delft), vele van onze discussies zul je verwerkt vinden in dit proefschrift. Jouw helder inzicht, je inspirerende persoonlijkheid en doorzettingsvermogen zullen mij steeds tot voorbeeld strekken.

DAVD PRICE (M.Sc. London), I shall always remember our many topics of discussion and your helpful cooperation in elucidating the disease aspect of the environmental conditions affecting plant growth.

Mijn dank gaat ook uit naar jullie, WILko J. Brzesowsky (l.i. Wageningen), Fred W. HASSELAAR en REen L. A. IJsSelmuiden, voor de enthousiaste geest van samenwerking bij de kartering en de vaak nog moeilijker taak van voorlichting.

I gratefully acknowledge the Management of the Cameroons Development Corporation for permission to publish these results. My thanks are also due to all the mem. bers of the Corporation's Research Division and the estate managers and their staff for their most valuable help and assistance. They are too numerous to mention all individually, but I would like to thank particularly Messrs. J. van Biesen, A. F. CouTts, D. J. EAST, A. F. Rainbow and L. A. Robertson in respect of the former, and Mr. J. W. Lowe, Palms Group Manager, in respect of the latter. 


\section{CONTENTS}

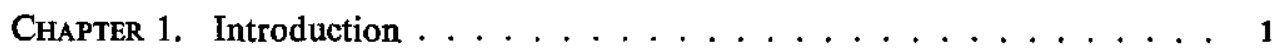

CHAPTER 2. The landscapes of the lower slopes of the Cameroon Mountain below the $300 \mathrm{ft}$. contour line $\ldots \ldots \ldots \ldots \ldots \ldots$

A. The Tiko plain .................. 2

B. The Mungo area . . . . . . . . . . . . . . . . . . 8

C. The M'Pundu-Meanja area . . . . . . . . . . . . . . . 8

D. The Duala basin . . . . . . . . . . . . . . . . 11

E. Soils and climate . . . . . . . . . . . . . 12

Chapter 3. The landscapes and soils of the lower slopes of the Cameroon Mountain above the $300 \mathrm{ft}$. contour line . . . . . . . . . . 14

A. The old volcanic landscape and soils . . . . . . . . . . 15

B. The young volcanic landscape and soils . . . . . . . . . . . 17

C. The volcanic soils . . . . . . . . . . . . . . 23

ChAPTER 4. The soils of the lower slopes of the Cameroon Mountain below the $300 \mathrm{ft}$. contour line . . . . . . . . . . . . . 25

A. Surveys . . . . . . . . . . . . . . 25

1. Photoanalysis . . . . . . . . . . . . . 25

2. Ground survey $\ldots \ldots \ldots \ldots$

B. Marine plateaux . . . . . . . . . . . . . . 27

1. River profiles . . . . . . . . . . 27

2. Outcrops ..................... 33

3. Extrapolation of the results to non-surveyed areas . . . . . . 33

C. Soil suitability and other applications . . . . . . . . . . . . 34

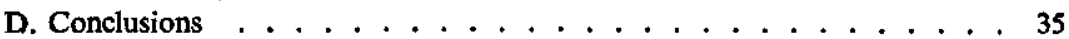

ChAPTER 5. The suitability of the lower eastern slopes of the Cameroon Mountain for various perennial crops . . . . . . . . . . 36

A. Introduction . . . . . . . . . . . . . 36

B. Chemical fertility of the soils . . . . . . . . . . . . . 37

C. Soil - crop relationships in bananas . . . . . . . . . . . . 39

1. Marine alluvial soils . . . . . . . . . . . . . . 39

2. Young volcanic soils . . . . . . . . . . . . . 51

D. Soil - crop relationships in oil palms . . . . . . . . . . . . 54

E. Soil - crop relationships in rubber . . . . . . . . . . 58

F. Soil - crop relationships in cocoa . . . . . . . . . . 61

G. Soil - crop relationships in tea . . . . . . . . . . 63

H. Summary: Mineral deficiencies of the soils of the lower slopes of the Cameroon Mountain .................. 63

Samenvatting ..................... 65

References ................... 66 


\section{CHAPTER 1}

\section{INTRODUCTION}

The Cameroons under United Kingdom Administration consists of two mountaineous strips of country on the eastern frontier of Nigeria and on the western frontier of the independent Cameroun Republic, stretching from Lake Chad to the Atlantic Ocean.

Geographically it is divided into two parts by a gap of some 45 miles near the Benue river. The southern parts of the territory are grouped for administration as the Southern Cameroons, which covers an area of 16,581 square miles $\left(4-6.5^{\circ} \mathrm{N}\right.$ lat., $8.5-11^{\circ} \mathrm{W}$. long.). The most southern administrative division is Victoria, which is mainly mountaineous. The Cameroon Mountain, an active volcano 13,350 feet high (30), dominates the ports of Bota, Victoria and Tiko, and the plantations of bananas, cacao, rubber, oil palms and tea nearby. Buea, the capital of the Southern Cameroons, lies at about $3000 \mathrm{ft}$. on its slopes, which are mostly covered with dense secondary forest.

Little is known of the early history of the Cameroons. The Cameroon Mountain was the "Chariot of the Gods" referred to by Hanno on the Carthagian expedition of 500 B.C., and the mountain is also shown on the Medicean map of 1351, or 1356, at Florence, known as the Laurentian Portalano (or "sailing directory"), which gave a very fair picture of the coast of the Gulf of Guinea and which, it can only be supposed, had been supplied by earlier Spanish and Genoese sailors. Towards the end of the fifteenth century Portuguese explorers, sailing past the great mountain, reached the Duala Estuary, which they called Rio dos Camaroes or Shrimp river, from the abundance of shrimps or small prawns found in the waters (49). The Spanish variant, Camarones, gave rise to the present anglicised name of Cameroons.

Europeans first established themselves in the southern part of the territory about the middle of the nineteenth century. Victoria was founded by the Baptist Mission in 1858 as a haven for freed slaves from the island of Fernando Poo.

In 1884 the German Government formally took the territory under its protection. It spent the ensuing twenty to thirty years extending its influence inland. On the outbreak of war in 1914 British and French forces invaded the Cameroons and by 1916 the country was provisionally divided into British and French spheres, which with slight subsequent modifications became the areas for which the League of Nations conferred mandates. The areas so defined were the subjects of the respective Trusteeship Agreements (the former French Cameroons attained independence on the 1st January 1960). The basis of the administration of the territory in international constitutional law is the Trusteeship Agreement approved by the General Assembly of the United Nations at New

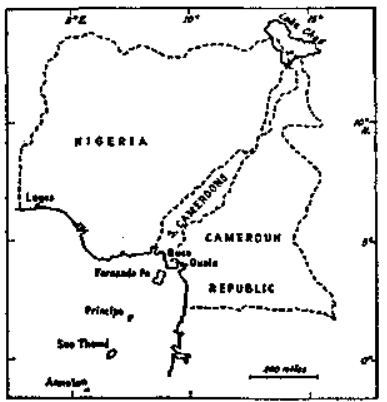

Figure 1 York on the 13th December 1946 (10).

The Cameroons Development Corporation was established by Ordinance (No. 39 of 1946) in 1947 to operate about 250,000 acres of plantations formerly belonging to German owners. The estates consist of banana, rubber, oil palm, cocoa and tea plantations, situated around the Cameroon Mountain range.

Briefly, the duties of the Corporation are to develop the resources of the lands 
placed under its control; to carry out such works and conduct such undertakings as may be necessary for the Corporation's business; to provide for social and other welfare facilities for the persons employed by the Corporation, as well as numerous other matters, which are incidental and conducive to the good and proper discharge of the functions of the Corporation.

Amongst the difficulties which have confronted the Corporation in formulating overall policies for an estate fragmented and only partially maintained, the first annual report of the Cameroons Development Corporation for the year 1947 mentioned:

"A lack of statistical and other vital information concerning the operations of estates in the past" and: "a complete absence of detailed survey information both in respect of contours and of soils".

In the Cameroons Development Corporation (briefly the C.D.C.) Ordinance No. 39 sub $6 \mathrm{i}$ of 1946, it was enacted, that it was the duty of the Corporation to carry out research and experimental work in matters connected with the functions of the Corporation. In 1953 it was decided to form a Research Section and in 1955 to have an aerial survey carried out: "to ensure that the Corporation's lands are put to the best and most economic use". Further particulars on the activities of the C.D.C. can be found in its annual reports (2).

In his function as a Soil Scientist of the Research Division of the C.D.C., the author laid down numerous fertilizer and husbandry trials in the three main crops, bananas, rubber and oil palms, and carried out detailed soil surveys on the lower slopes of the Cameroon Mountain, part of the results of which are published in this treatise.

\section{ChaPTER 2}

\section{THE LANDSCAPES OF THE LOWER SLOPES OF THE CAMEROON MOUNTAIN BELOW THE 300 FT. CONTOUR LINE}

After the completion of the aerial survey of the Corporation's plantations carried out in the dry season of 1955/56, a soil survey was begun in 1957 in an area below the $300 \mathrm{ft}$. contour line on parts of the northeastern, eastern and southeastern slopes of the Cameroon Mountain at M'Pundu - Meanja near Ekona, in the Mungo area along the Mungo river and in the Tiko plain respectively. The present study is based upon some aspects of the results obtained from the survey on the ground and the photoanalytical interpretation of the aerial photographs.

\section{A. The Tiko Plain}

The Tiko plain is bordered in the northeast by the Mungo river, boundary between the Southern Cameroons and the Cameroun Republic, in the southeast by the mangroves of the Duala Estuary, in the southwest by the Ombe river and the mountaineous area of Mabeta, and in the northwest by an escarpment formed by the lower slopes of the Cameroon Mountain, which rises steeply out of the Tiko plain up to $300 \mathrm{ft}$. or more, but for the most north eastern part, the so called Mungo area, where the escarpment bends to the north and runs parallel to the Mungo river.

The Tiko plain can be divided into two parts, i.e. the western half consisting of soils of recent volcanic origin from the Ombe river eastwards over a distance of 7 miles to the Sonne river, and an area with soils of non-volcanic origin from the Sonne river eastwards to the Mungo river, a distance of 9 miles.

The volcanic western half of the Tiko plain rises gradually out of the mangroves, the 
slope becoming steeper as from the $220 \mathrm{ft}$. contour line up to $300 \mathrm{ft}$. (cf. table 8). The contour lines run broadly speaking straight from southwest to northeast over the entire length of the Tiko plain and parallel to the mangroves. There is one major interruption which is due to an extinct volcano, the Benoe crater, in the middle of this section near the $300 \mathrm{ft}$. line. Its main crater is $300^{\prime}$ high and has well preserved crater walls. Smaller eruption points rise to altitudes of approximately $500^{\prime}$. Going from this crater east-wards volcanic mud flows descended in rather recent geological history into the Tiko plain. These flows originated from craters situated further inland and resulted in the boundary with the mangroves being pushed further seawards. Consequently, the width of the Tiko plain increases from 2 miles at its southwestern boundary to $3 \frac{1}{2}$ miles in the area east of the Benoe crater towards the end of the volcanic part of the Tiko plain. It will be seen in chapter 4 that the latter area, consisting of the Ikange-Holtfoth section, is of the utmost importance for the interpretation of the physiography and the reconstruction of the geological events of the land lying below the $300^{\prime}$ contour line all around the Cameroon Mountain. This key area is enclosed by the Sonne river in the east, and the Benoe river and the Benoe crater in the west.

Subsequently, abrasion of the newly formed land by sea currents, probably combined with alternating sea levels, resulted in the formation in several places of an abrupt transition from land to mangroves, covering in some cases differences in altitude of up to $40 \mathrm{ft}$. Tiko town itself is built on such a "cliff". Beach formations, consisting of long drawn bundles of ridges built of sand and rising to several feet above the surrounding mangrove swamps, lie perpendicular to the coast. They may be compared with the "ritsen" described by VAN DER EYK in Surinam (18),

Between the ridges, there are deep tidal creeks, allowing ocean going vessels to enter Tiko wharf, itself built on a 2 mile long coastal beach formation and situated as far as 11 miles inland in the mangroves.

Another observation made in the volcanic part of the Tiko plain was, that some of the rivers, particularly those which debouch into the mangroves at or near the abrased "cliff", are deeply cut in from the $120^{\prime}$ or the $220^{\prime}$ contour line downwards. The crossing of either of these two levels by the rivers is indicated by rapids (cf. chapter 4 , table 8). The latter phenomenon, i.e. the occurrence of "thresholds" in the rivers, will appear not to be confined to the volcanic part of the Tiko plain, indeed it will be shown to be characteristic for the strip of land lying below the $300^{\prime}$ contour line all around the Cameroon Mountain. Finally, it was observed that crossing the volcanic part of the Tiko plain lengthwise, i.e. in an east-west direction, the land is slightly undulating. The latter microrelief is related to the absence or presence of rivers, in such a way that the major rivers are situated on top of the ridges and the land lying between two major rivers occupies the lower part of the landscape. It is more obvious in the strip of land below the $120^{\prime}$ contour line than above it.

The general drainage pattern of the Tiko plain is from northwest to southeast, hence perpendicular to the general direction of the contour lines. Exceptions to this pattern either because of local deviations of the contour lines or as a result of a diverted river course will be discussed in detail in chapter 4.

The slight deviation in the general direction of the contour lines in the area just below the Benoe crater will, however, not be discussed any further as it is considered to be localised to the actual formation of the crater and its efflata.

The landscape of the northeastern half of the Tiko plain, i.e. from the Sonne river northeastwards to the Mungo river, is in several respects quite distinct from that of the more western half. It can be subdivided into an area between the Sonne river and the Essoasso river, a distance of $1 \frac{1}{2}$ miles, the so called Sonne section, and an area north- 
east of the Essoasso river to the Mungo river, a distance of approximately $7 \frac{1}{2}$ miles.

The Sonne section covers a transitional zone between the volcanic and the non volcanic soils. The former were found to be deposited on top of the latter, the transition being marked by a distinct change in colour, as will be seen from the following profile description at a depth of $140 \mathrm{~cm}$ (table 1).

The width, i.e. from the $300^{\prime}$ contour line to the mangroves in the southeast, in the transitional area of the Sonne section is $3 \frac{1}{2}$ miles and increases, going in an eastern direction, to 5 miles and near the Mungo river to $9 \frac{1}{2}$ miles. The land gradually slopes up from the mangroves to the $300^{\prime}$ contour line, hence the slope of the land is steeper in the southwestern compared with the extreme northeastern part. The contour lines run generally in a S.W.-N.E. direction more or less parallel to the coast line. But, whereas the distance between successive contour lines on the volcanic soils is approximately the same, decreasing only slightly and uniformly with increasing altitude, the interval between the contour lines in the non-volcanic part of the plain is much larger near the mangroves and decreases more rapidly, particularly above the $220^{\prime}$ contour line. The non-volcanic landscape has therefore a more concave form.

A profile description of a poorly drained type of a non-volcanic soil is shown in table 2 .

Another peculiarity of the landscape of the non-volcanic part of the Tiko plain is the occurrence of outcrops. In the volcanic part only one outcrop (the Benoe crater being of a more recent age is excluded) was encountered, i.e. in the extreme southwestern part of it near the mangroves at the mouth of the Ombe river. It is $120^{\prime}$ high and is undoubtedly part of the nearby and hilly Mabeta area just across the Ombe river. On these outcrops lateritic hardpans occur at the surface, similar to those encountered at variable depth in the profiles of the more level parts of the eastern half of the Tiko plain. Coarse grained basalt blocks were invariably found on the surface of these outcrops together with lateritic boulders, both being rounded off. It would seem, therefore, that the lateritic crust, formed in situ, has been raised locally during ante-Quaternary basalt irruptions. Thereafter, the landscape was transformed and levelled, as will be discussed later, by marine erosion in the Quaternary era. The latter action also explains the rounded form of both the lateritic and basalt boulders. Similar observations were made by Sieffermann (46) in the western half of the Cameroun Republic.

Whereas the soils on the more level parts consist of yellowish brown (Munsell colour range: 10 YR) sandy clays of variable depth overlying lateritic hardpans (cf. table 1 $\& 2$ ), the soils on the outcrops, where the lateritic hardpan has been broken up, consist of reddish brown ( 5 to $7.5 \mathrm{YR}$ ) heavy clays overlain by a more or less thin layer of the same yellowish brown sandy clays as encountered in the more level parts.

It was noted that the outcrops, which vary in height from $3^{\prime}$ to $20^{\prime}$, occur predominantly in the extreme northeastern part of the Tiko plain and in the lower lying strip of land along the mangroves, i.e. below the $120^{\prime}$ contour line.

It was already mentioned that generally the contour lines run parallel to each other and the mangroves.

There is however, one exception, viz. approximately in the middle of the nonvolcanic section of the Tiko plain, where the contour lines of $120^{\prime}$ and lower bend sharply southeast towards the mangroves, whereas the contour lines of more than $120^{\prime}$ are gradually beginning to bend in the opposite direction, where the escarpment bordering the Tiko plain begins to bend to the north. The divergency of the contour lines at this point is due to volcanic flows, called the Mondoni flows, which are of much older age than those in the volcanic part of the Tiko plain. Firstly, because of the absence of unweathered volcanic fragments and, secondly, because the sandy clays of 


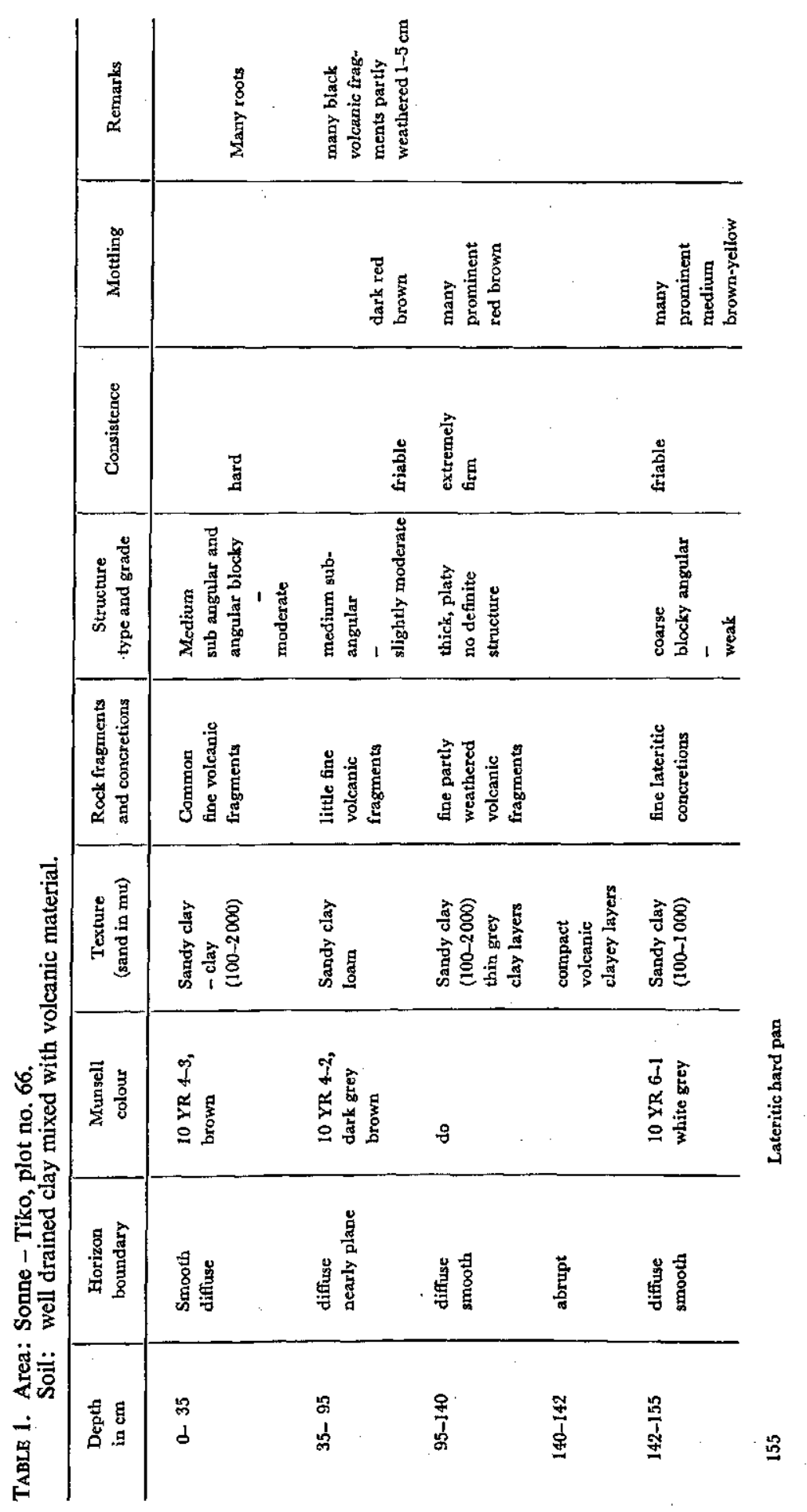




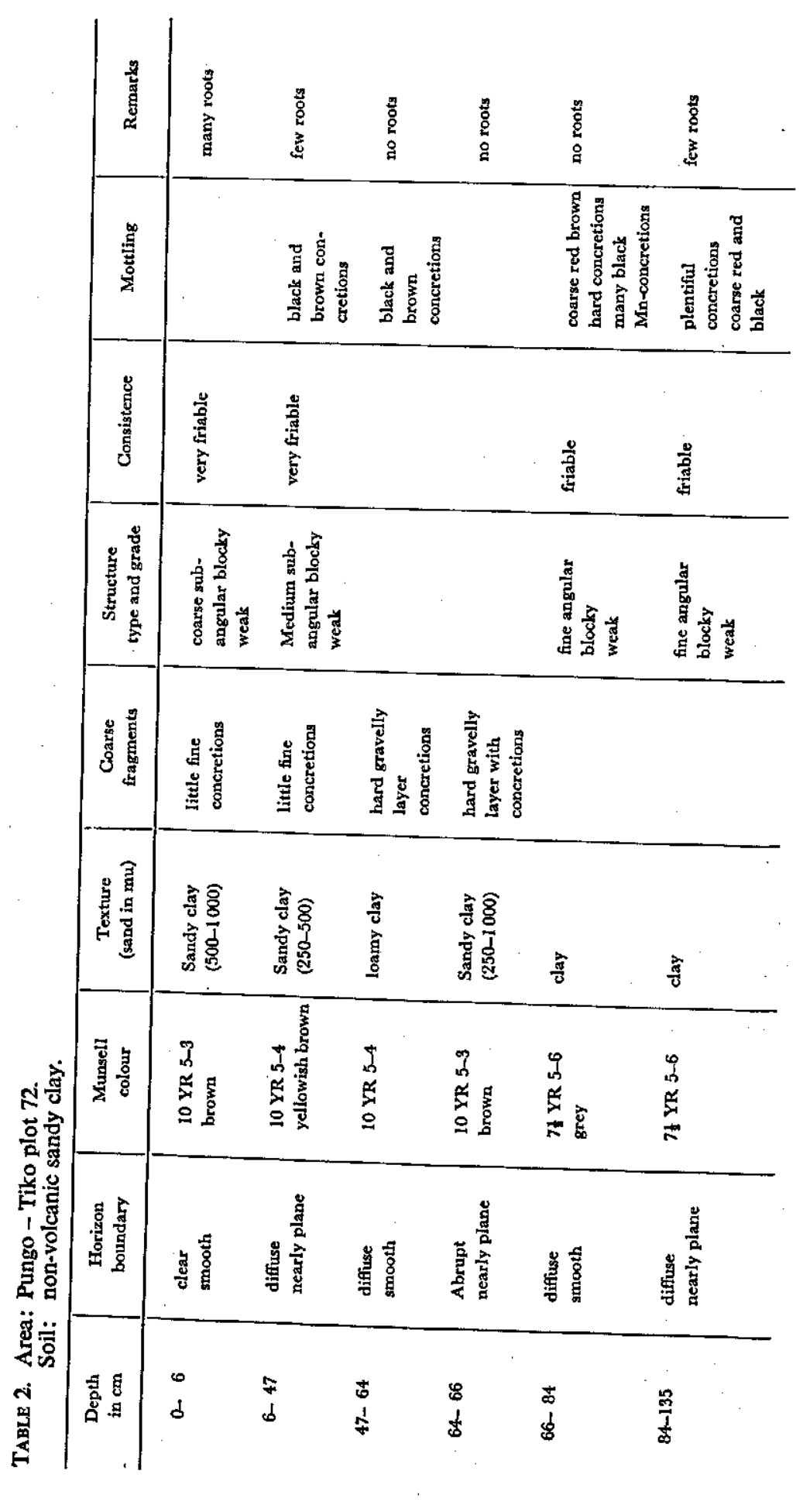


marine origin, found to be overlain by black volcanic material in the transitional zone of Sonne section, were here found to be lying on top of the more reddish and less sandy clays of old volcanic origin. The latter was shown to be particularly noticeable on the outcrops.

Additional evidence for the difference in age of the volcanic material was provided by a study of the physiography of the hinterland by means of stereoscopical analysis of the aerial photographs. The Sonne river, which was seen to be the border between the two parts of the Tiko plain, appeared to represent also the border in the hinterland, i.e. above the $300^{\prime}$ line. Whereas the hinterland of the volcanic part is undulating, that of the eastern half is very broken mountaineous terrain, covered with red and heavy clays.

The hinterland west of the Sonne river is young volcanic and set with extinct but often well preserved craters spread around a line from N.N.E. to S.S.W., which ends in the south at the Benoe crater just inside the Tiko plain. Their deposits must have filled up the previously more dissected landscape as well as the volcanic part of the Tiko plain.

In the hinterland east of the Sonne river no relic craters were found except at the extreme northeastern side of it, where the contour lines of the higher altitudes bend to the north and those of $120^{\prime}$ and below in the opposite direction.

It is, therefore, reasonable to relate the deviation of the latter with volcanic flows, which originated from these eruption points. Moreover, it explains why the area covered by this flow is bestrewn with basalt boulders.

It appears from this picture of the pre-Quaternary landscape of the eastern half of theTiko plain that the Mondoni flows extended far down into the plain causing the marked deviation of the lower contour lines. It will be demonstrated in chapter 4 , that at a later date the landscape was further altered under the influence of alluvial deposits of marine origin resulting in the deposit of yellowish brown sandy clays originating from Precambrian parent material. It is because of the latter that the eastern half of the Tiko plain has been referred to as to be of non-volcanic origin, notwithstanding its subsoil is, at least partly, of ante-Quaternary volcanic origin.

Relics of pre-volcanic formations, i.e. of Precambrian origin, the basement rocks (gneisses, schists) of the African shield and/or of the sedimentary basin of Nigeria and Duala considered to be of Tertiary age (cf. paragraph D: the Duala basin), were only encountered in the most northeastern part of the Tiko plain, along the Tiko-M'Pundu railway line near the Mungo river and in its hinterland.

The eastern half of the Tiko plain is also drained from N.W. to S.E. except in the case of the Mondoni river, which runs on top of the Mondoni flow down to 120' whereafter it takes a more eastern course in line with the change of the contour lines at this level. Except in the transitional Sonne section, neither of the rivers in the eastern half is deeply cut in below the $120^{\prime}$ line. Above that level, particularly above the $220^{\prime}$ line, however, they have all formed very deep and often wide valleys, which extend far beyond the $300^{\prime}$ line into the very broken hinterland east of the upper course of the Sonne river. The "thresholds" in the valley bottoms of the rivers in the volcanic part of the Tiko plain were also observed in the eastern part and again at the crossing of the $120^{\prime}$ and $220^{\prime}$ contour lines.

There is only one large swamp above sea level, viz. in the extreme northeastern part between $100^{\prime}$ and $120^{\prime}$ contour line, owing to the generally uniform gradient of the Tiko plain. There are, however, several badly drained patches, which are usually situated near outcrops or, in the western half of the Tiko plain, at the fronts of volcanic flows. 


\section{B. The Mungo area}

The Mungo area is bordered in the north by the M'Pundu-Meanja area, in the east by the Mungo river, in the south by the northeastern part of the Tiko plain, the boundary being the Koke river, and in the west by the same escarpment which borders the Tiko plain and which was shown to bend to the north in the northeastern part of the Tiko plain. The Mungo area can, therefore, be considered as the continuation of the Tiko plain, that is that part of it which is situated above the $120^{\prime}$ line. For, the part of the Mungo area situated below 120' consists of a very narrow strip of flat land along the Mungo river, actually part of the Mungo river valley. It varies in width from 100 yards to half a mile where the river has made inroads on the surrounding higher lying land.

From the Mungo river valley at about $20^{\prime}$ above sea level the land rises steeply up to $100^{\prime}$ or $120^{\prime}$ in the southern half of the section and up to $200^{\prime}$ in the northern half. In the latter case the slope is broken by a less steep or slightly sloping part at the $120^{\prime}$ level, hence the level at which the rapids occur in the rivers in the Tiko plain.

The contour lines run parallel to each other in a north-south direction in the northern half of the section, but especially those above $120^{\prime}$ take a more southwestern course in the southern half, thus following the bend in the $300^{\prime}$ escarpment, having been shown to be the extension of the one bordering the Tiko plain. At the bending point the continuous slope up to $200^{\prime}$ of the northern half of the area is divided into two independent slopes, the one up to $120^{\prime}$ continuing its course parallel to the Mungo river, the contour lines up to $200^{\prime}$ following the change in direction of the $300^{\prime}$ escarpment and at the same time diverging. The latter divergency results in the landscape becoming less steeply sloping, the distance between the $120^{\prime}$ and $220^{\prime}$ lines reaching a maximum of one mile. This landscape is interrupted by the Koke river, a tributary of the Mungo river. It has formed a wide valley up to the $120^{\prime}$ line in which it has not cut itself in again. At the $120^{\prime}$ line there is a waterfall and above it the valley is very deeply cut in, also because it is at this point that the contour lines up to $220^{\prime}$ have converged again to one bundle forming a valley wall of approximately $100^{\prime}$ deep. A repetition of this phenomenon occurs at the point where the river bed crosses the $220^{\prime}$ line. Above the $120^{\prime}$ line the Koke river valley becomes narrower, has a steeper gradient and is full of basalt boulders, probably originating from the large Mondoni lava flow. Where the course of the Koke river leaves the area of the Mondoni lava flow at $120^{\prime}$ above sea level, it bends east, in line with the observation made in respect of the Mondoni river in
the 'Tiko plain.

The plateau between $200^{\prime}$ and $300^{\prime}$ in the northern half of the area is less than a mile wide and, owing to the diverging contour lines, the width decreases going in a southern direction to almost nil at the point, where the Koke river passes the $220^{\prime}$ line. The distance from north to south, i.e. from the power line, the boundary with the M'PunduMeanja area in the north, to the Koke river varies from $1 \frac{1}{2}$ to $2 \frac{1}{2}$ miles.

As a whole the area is well drained. Apart from the swamps occurring in the valleys along the $220^{\prime}$ and $300^{\prime}$ contour lines.

\section{The M'Pundu-Meanja area}

The M'Pundu-Meanja area is bordered in the east by the Mungo river, in the south by the Mungo area, in the west by the $300^{\prime}$ contour line and in the north by the Zupe
river and the C.D.C. concession boundary.

The southern part is called the M'Pundu area, the northern part the Meanja area, the boundary being the M'Pundu river. 
The $300^{\prime}$ escarpment coming from the Mungo area continues at first its northern course but it gradually follows a more north-northwestern direction between M'Pundu and Meanja, at the same time becoming less steep. It remains, however, a clear demarcation line between the more level land below it, and the more broken and steeper (i.e. in the M'Pundu area) or more undulating and sloping land (i.e. the Meanja area) above it.

Going upstream from the boundary between the Mungo and the M'Pundu area, the Mungo river bends to the northeast over a distance of about one mile, whereafter it again flows from north to south. Whereas the level of the land, in which the Mungo river is cut in, is $200^{\prime}$ above sea level at the boundary with the Mungo area, it is only $160^{\prime}$ where the river bends to the northeast, $140^{\prime}$ where it bends to the north again and $120^{\prime}$ in the Meanja area and further north. As in the Mungo area there is a break in the slope of the valley wall at about $120^{\prime}$ above sea level. It is of interest to note that, going downstream from north to south, the Mungo river plateau becomes higher, consequently its valley deeper, also owing to - though to a much lesser extent - the gradient of the valley bottom, which is about $30^{\prime}$ above sea level upstream at Meanja and $15^{\prime}$ downstream in the Mungo area. Besides, going downstream, the valley becomes narrower until it reaches the Tiko plain.

Thus, it appears that the shorter the distance between the Mungo river valley and the $300^{\prime}$ contour line, the higher the level of its plateau. The explanation for it was found to be related to the distance covered by pre-Quaternary lava flows. It was shown that the Mondoni lava flows extended far down into the Tiko plain and had a marked influence on the topography, i.e. by altering its uniform pattern. It was also noticeable in the Mungo area, but only down to a level of between $200^{\prime}$ and $120^{\prime}$ as against a level of less than $80^{\prime}$ in the Tiko plain, the main direction of the Mondoni flow, hence from northwest to southeast. The eruption points from which the Mondoni lava flows originated are part of a range of craters arranged along a north to northwestern axis, extending into the M'Pundu and Meanja areas. The length of the volcanic flows originating from this axis of eruption appeared to be the determining factor in the distance between the Mungo river valley and the $300^{\prime}$ contour line, which more or less coincides with the eruption axis. Hence, where the influence of the lava flows extended to the $200^{\prime}$ contour line, as in the northern half of the Mungo area, the Mungo river valley reached this same level, but where the lava flows extended further downwards, as in the M'Pundu and Meanja areas, the valley was also found to be situated there.

It was shown previously that going upstream from the Mungo to the M'Pundu area the Mungo river bends from a northern to a northeastern direction while at the same time the altitude of its plateau decreases. It was evident from the interpretation given above that the lava flows extending to lower levels formed an unsurmountable barrier as a result of which the Mungo river was forced to a change in its course. In other words, the decisive factor in the present course of the Mungo river was not the Mungo river itself, but the lava flows, which forced the river to follow a certain course.

This is in line with the observations made by NICKLES (36), who studied the geology of the Cameroun Republic and stated about the Duala basin, i.e. the area east of the Mungo river opposite the Tiko plain, the Mungo and M'Pundu-Meanja areas, that: "Aucune intrusion (volcanique) n'est connue dans le bassin de Douala. Assez paradoxalement donc, quelques failles peu importantes sont ici les seuls témoins d'événements voisins, qui sont à l'échelle du globe."

Careful study of the contour lines of the area along the Mungo river revealed that the ante-Quaternary lava flows follow a course from $N$. to $S$. in the Mungo area down into the Tiko plain, whereas in the M'Pundu-Meanja area they followed an eastern 
course. Outside the area of the volcanic flows, i.e. north of Meanja, the level of the Mungo plateau is consis tently $120^{\prime}$ above sea level. It could be compared with the uniform topography of the eastern half of the Tiko plain outside the Mondoni lava flow, in the hinterland of which eruption points were not apparent. It appeared on inspection of this very broken hinterland that it is only partly covered with volcanic efflata and consists of basement rocks of Precambrian age (granites, gneisses, and schists VINE [50]) and/or Tertiary deposits (sandstones, shales - NICKLES [36]).

According to Geze (21) the Basement Complex has been uplifted by tectonical forces to 100 meters (i.e. the $300^{\prime}$ contour line) above the present sea level. It extends through and along the coast of the Cameroun Republic to Spanish Guinea. The only place where it was found to be exposed below the $300^{\prime}$ line was in the extreme northeastern part of the Tiko plain. This explains also the conspicuous nature of the $300^{\prime}$ line in the landscape of the lower slopes of the Cameroon Mountain. The Precambrian Complex of above the $300^{\prime}$ escarpment was shown to be overlain in several places by volcanic deposits, which owing to their degree of weathering (Mondoni flow, outcrops) are of pre-Quaternary, according to GEZE (21) Tertiary origin. As in the western part of the Tiko plain, the old volcanic flows of the Meanja area are covered with younger, slightly weathered volcanic deposits, thereby masking even more the conspicuous nature of the $300^{\prime}$ escarpment. The landscape of Meanja shows much resemblance with that of the western half of the Tiko plain, but whereas in the latter area the young volcanic deposits extend down to sea level, they did not progress further than the $220^{\prime}$ contour line at Meanja.

The complex nature of the landscape of the M'Pundu-Meanja area is the result of volcanic flows of Tertiary and Quaternary age, the latter deposited on top of the former. They are underlain by a prevolcanic landscape of Precambrian and/or sedimentary Tertiary origin, relics of which were, however, not encountered, except in specific aspects of the landscape, foremost amongst which is the $300^{\prime}$ escarpment.

There are two major rivers, the M'Pundu and Zupe, which debouch into the Mungo river. Their tributaries are the Malele and Ombele river respectively. Neither of them has a specific direction, owing to the complex nature of the topography of the area.

The M'Pundu river runs from southwest to northeast, takes a more eastern course at the junction with the Malele river, and finally running from N.W. to S.E. debouches into the Mungo river (table 8, river profiles). The Malele river runs from west to east down to the $220^{\prime}$ line and thereafter in an almost straight line from N.W. to S.E. into the M'Pundu river by means of a waterfall at the 140' contour line.

The Zupe river runs from N.N.W. to S.S.E., but below the $120^{\prime}$ contour line from west to east. It debouches into the Mungo river less than a mile north of the M'Pundu river. Its tributary, the Ombele, runs from S.W. to N.E. and joins the Zupe river with a steep gradient as from the $100^{\prime}$ contour line.

A very deep valley with a rivulet running in it - the M'Pundu oil mill valley-extends from the M'Pundu oil mill, situated at the Mungo river near the boundary with the Mungo area, to the northwest. It is $180^{\prime}$ deep near the Mungo river, and about $100^{\prime}$ deep, where its valley floor crosses the $120^{\prime}$ contour line. The rivulet is hardly cut in above the $220^{\prime}$ contour line, where it, moreover, bends almost rectangularly to the S.W., parallel to and only some 400 yards away from the upper course of the M'Pundu river. The seemingly arbitary course of the rivers is closely related to the complex nature of the topography. It will be discussed in more detail in chapter 4.

Unlike the Mungo area, but in line with and even more so than in the eastern half of the Tiko plain, the landscape of Meanja and particularly of M'Pundu is dominated by a number of outcrops. Usually, they are $300^{\prime}$ high in the area enclosed by the $300^{\prime}$ and 
$220^{\prime}$ contour lines, $220^{\prime}$ between the $220^{\prime}$ and $120^{\prime}$ contour lines and $120^{\prime}$ below the $120^{\prime}$ contour line. As in the Tiko plain, they must be considered as pre-Quaternary irruptions in the Precambrian Basement Complex.

Swamps are frequently encountered at the foot of the outcrops, and also at the front of young volcanic flows.

From north to south the M'Pundu-Meanja area is some 4 miles long and from east to west, i.e. from the $300^{\prime}$ contour line to the Mungo river, about 1 mile wide at its southern boundary, gradually widening to almost 3 miles in the Meanja area, and even more north of the Meanja area.

\section{The Duala Basin}

It is of interest to compare the physiography of the areas below the $300^{\prime}$ contour line in the Southern Cameroons, with the neighbouring area in the Cameroun, east of the Mungo river, the so called Duala basin.

NICKLES (36) describes it as a flat and low lying basin of $7000 \mathrm{~km}^{2}$, consisting mainly of riverine alluvial deposits, different kinds of crusts ("carapaces") and basaltic flows.

Stratigraphically, NICKLES considers these deposits to be $6000 \mathrm{ft}$. deep, consisting of thick layers of riverine and/or marine origin, divided by fossiliferous layers of marine origin. The succession is as follows:

Recent alluvium, coastal sands, mangroves ... . . . . . . Q Quaternary mottled sands and clays . . . . . . . . . . $100 \mathrm{~m}$ ? Plio-Pleistocene sandstones, often calcareous, sometimes marlaceous, coloured grey or yellow and

black or grey respectively . . . . . . . . . . $400 \mathrm{~m}$ Middle Eocene white, yellow, reddish or purplish sandstones, with ferruginous crusts, intercalated with kaolinitic sandstones and grey, purplish or white clays . . $600 \mathrm{~m}$ Paleocene shales and sandstones, fossiliferous limestones and tuffs, and basalt boulders, pyrite and lignite . . . . . . . . . . . $500 \mathrm{~m}$ Upper Cretaceous non-fossiliferous micaceous and coarse sandstones, intercalated with finer sandstones and traces of coal ........... . $600 \mathrm{~m}$ Lower Cretaceous

\section{Basement Complex.}

It is of interest that pyrites and lignites were also found in the Malende plantation some $5 \frac{1}{2}$ miles north of Meanja in the $120^{\prime}$ Mungo river plateau near the Mungo river at a depth of approximately $30 \mathrm{ft}$.

The sedimentary Duala basin is considered to be part of the sedimentary basin of Nigeria $(36,50)$ and is underlain by the Basement Complex. Géze (21) states the following in respect of the granitic-gneissic Basement Complex:

"Avec une assez grande fidelité, la courbe de niveau de 100 mètres marque la limite occidentale du socle ancien, souvent rectiligne et qui parait resulter au moins d'une flexure sinon de failles. Les fleuves sont toujours coupés de pittoresques rapides au passage du socle ancien vers les couches sédimentaires."

The 100 meters contour line is the $300^{\prime}$ escarpment which borders the Tiko plain in a straight line from S.W. to N.E., and the Mungo and M'Pundu-Meanja areas from south to north to northwest.

It was shown to be overlain by volcanic flows of Tertiary age, in some places subsequently being covered by more recent, i.e. Quaternary, flows. Where the latter reached the sedimentary soils of below $300^{\prime}$ they were shown to be overlying them (profile description table 1). The absence of volcanic flows in the lower parts of the Duala basin (36) lended further support to the present course of the Mungo river, it 
being defined by the distance the volcanic flows covered in the area below 300 ' in the Mungo and M'Pundu-Meanja areas.

For, the further down these flows descended, the larger the distance between the Mungo river and the $300^{\prime}$ escarpment.

These observations are in line with those of NicKLEs (36):

"Les coulées basaltiques de la région de M'Banga (some 16 miles north of the Meanja area) reposent au Nord directement sur le Socle, puis sur une surface érodée des grés de base vers le Sud, s'avançant mêtme à leur extrémité méridionale jusqu'à la partie du Crétace supérieur" and

"Leur âge (of the flows) ne peut être indiqué. Mais la présence dans le Crétace supérieur du Moungo (the Mungo river), de tufs basaltiques et de cendres, montre que ces phénomènes ont debuté au Crétace supérieur. Ils se sont poursuivis, avec de longues périodes de repos, jusqu'à une époque récente."

The Quaternary sediments are deposited along the present coast line and are described by NICKLÈs as follows:

"sables cotiers, vases noires de la mangrove et alluvions récentes des fleuves, représentent les sédiments actuels. Des forages effectués dans le lit du Wouri (a river running parallel to the Mungo river in the Duala basin) ont montré qu'à un creusement important a succédé une phase active de remblaiement, car l'épaisseur des alluvions rencontrés là atteint $50 \mathrm{~m}$. Faute d'avoir pu effectuer un nivellement précis, les terraces anciennes n'ont pu être individualisées. On doit également rattacher au Quaternaire, certaines carapaces résultant du lavage des sables et argiles bariolés."

The Quaternary deposits are of major interest in this study and will be discussed in detail in chapters 3 and 4, while "the carapaces résultant du lavage des sables et argiles bariolés" will be related to the fragipans found at varying depth in the volcanic soils of the western half of the Tiko plain.

\section{E. Solls and Climate}

Prior to the more detailed discussion of the different soils in chapters 3 and 4 and of their suitability for growing crops in chapter 5 , some general remarks will be made here about the degree of weathering in relation to the age of the former and about the climate as a factor in the assessment of the latter respectively.

\section{Soils}

The soils can be divided into lateritic and non-lateritic soils according to their degree of weathering, hence their age. The lateritic soils are developed on basement rocks of Precambrian age, on Cretaceous sediments and on volcanic parent material of Tertiary age. The soils developed on basement rocks and on Cretaceous sediments were not encountered in the areas under consideration. Relics of these soils, i.e. their lateritic hardpans, however, were sometimes encountered underlying shallow deposits of Quaternary age. The lateritic soils of Tertiary volcanic origin, on the other hand, are wide-spread.

GÈZE (21) distinguishes three eras of laterisation: the first period being of Cretaceous age, the second one of Palaeocene age and the third one probably originating from the end of the Tertiary and the beginning of the Quaternary era, but differing from the former two in intensity of laterisation and in the end products.

Laterization of basalts and sediments of Quaternary age has not taken place, which 
according to Gizze may have been due to climatic conditions different from those of the middle Tertiary, extending probably into the Ice age, when the equatorial conditions favourable for laterisation processes were restored. Consequently, the latter author concluded: "au Cameroun les laterites sont toujours des formations anciennes, pouvant être datées stratigraphiquement."

\section{Climate}

The climate in the areas on the southern and southeastern slopes of the Cameroon Mountain, i.e. in the Tiko plain, the Mungo and M'Pundu-Meanja areas, is characterized by a pronounced dry and wet season. The dry season extends from the middle of November till the end of February, and the rainy season from the middle of June till the middle of October (cf. tables 3 and 4).

The rainy season is very deficient in sunshine (average 1 hour/day), but relatively also the dry season owing to cloudiness and the, so called, harmattan winds covered with Sahara dust (average 3-5 hours/day).

The change from wet to dry, and particularly from dry to wet season is attended by violent thunderstorms, frequently causing considerable losses of bananas and rubber to wind damage $(22,25)$. These storms are caused by the seasonal movement of the "inter tropical front", i.e. the line running east and west, which divides the land areas of West Africa into two parts, so that every point to the north of this line experiences winds from a north-easterly direction and every point to the south of it experiences winds from a south-westerly direction. The E.-N.E. winds, which blow across the land mass bring down dust from the desert in the dry season and give harmattan haze or may suddenly undercut the monsoon to the south of the Inter Tropical Front and produce a line squall, i.e. a belt of intense storms with the mentioned disastrous results for bananas and rubber (1).

Weather data for Meanja and Ekona are given in tables 3 and 4, and are principally the same for the three areas under consideration.

TABLe 3. Monthly mean values (Average for period May 1956-May 1960). Ekona: altitude $1300^{\prime}$ above M.S.L.

\begin{tabular}{|c|c|c|c|c|c|c|c|c|}
\hline \multirow{2}{*}{\multicolumn{2}{|c|}{ Month }} & & \multicolumn{2}{|c|}{ Temperature $\left({ }^{\circ} \mathrm{F}\right)$} & \multirow{2}{*}{$\begin{array}{c}\text { Relative } \\
\text { Humidity } \\
(\%)\end{array}$} & \multirow{2}{*}{$\begin{array}{l}\text { Hours } \\
\text { Sunshine }\end{array}$} & \multirow{2}{*}{$\begin{array}{l}\text { Rainfall } \\
\text { (inches) }\end{array}$} & \multirow{2}{*}{$\begin{array}{l}\text { No. of } \\
\text { rainy days }\end{array}$} \\
\hline & & & Max. & Min. & & & & \\
\hline $\begin{array}{l}\text { January . } \\
\text { February . } \\
\text { March . } \\
\text { April . . } \\
\text { May . . . } \\
\text { June . . . } \\
\text { July . . . } \\
\text { August . . } \\
\text { September } \\
\text { October . } \\
\text { November } \\
\text { December. }\end{array}$ & 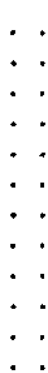 & 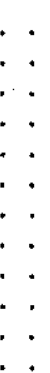 & $\begin{array}{l}82.7 \\
84.8 \\
84.6 \\
83.8 \\
82.6 \\
79.5 \\
75.8 \\
76.0 \\
78.7 \\
80.6 \\
81.3 \\
83.0\end{array}$ & $\begin{array}{l}66.9 \\
67.1 \\
67.6 \\
69.0 \\
68.5 \\
68.1 \\
67.9 \\
67.9 \\
68.3 \\
68.0 \\
67.7 \\
66.2\end{array}$ & $\begin{array}{l}86.0 \\
85.5 \\
84.1 \\
85.2 \\
85.2 \\
88.6 \\
90.7 \\
90.6 \\
90.1 \\
88.7 \\
88.6 \\
86.8\end{array}$ & $\begin{array}{r}123.5 \\
154.7 \\
118.2 \\
134.4 \\
120.7 \\
63.4 \\
29.9 \\
24.7 \\
44.8 \\
99.5 \\
101.3 \\
142.9\end{array}$ & $\begin{array}{r}1.4 \\
0.2 \\
4.8 \\
6.8 \\
6.6 \\
8.9 \\
13.9 \\
14.4 \\
10.6 \\
9.5 \\
6.0 \\
1.5\end{array}$ & $\begin{array}{r}2.0 \\
1.7 \\
8.7 \\
11.5 \\
15.1 \\
19.0 \\
27.0 \\
28.3 \\
25.3 \\
22.8 \\
12.3 \\
3.7\end{array}$ \\
\hline
\end{tabular}

It will be seen from tables 3 and 4 that during the heavy rains there is little sunshine and that during the dry season there is much sun but little or no rain. There is in fact a highly significant negative correlation $(r=-0.9)$ between the number of rainy days and the hours of sunshine. This suggests, that most of the rain falls during the hours of day 
TABLE 4. Monthly mean values (Average for 1958 and 1959) Meanja: altitude $180^{\prime}$ above M.S.L.

\begin{tabular}{|c|c|c|c|c|c|c|c|c|}
\hline \multirow{2}{*}{\multicolumn{3}{|c|}{ Month }} & \multicolumn{2}{|c|}{ Temperature $\left({ }^{\circ} \mathrm{F}\right)$} & \multirow{2}{*}{$\begin{array}{c}\text { Relative } \\
\text { Humidity } \\
(\%)\end{array}$} & \multirow{2}{*}{$\begin{array}{l}\text { Hours } \\
\text { Sunshine }\end{array}$} & \multirow{2}{*}{$\begin{array}{l}\text { Rainfall } \\
\text { (inches) }\end{array}$} & \multirow{2}{*}{$\begin{array}{l}\text { No. of } \\
\text { rainy days }\end{array}$} \\
\hline & & & Max. & Min. & & & & \\
\hline $\begin{array}{l}\text { January } \\
\text { February : } \\
\text { March . } \\
\text { April . . } \\
\text { May . . } \\
\text { June . . } \\
\text { July : . } \\
\text { August . : } \\
\text { September } \\
\text { October . } \\
\text { November } \\
\text { December. }\end{array}$ & $\begin{array}{l}\cdot \\
\cdot \\
\cdot \\
\cdot \\
. \\
. \\
. \\
. \\
. \\
. \\
. \\
. \\
. \\
. \\
.\end{array}$ & 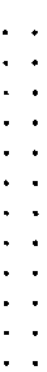 & $\begin{array}{l}88.5 \\
90.5 \\
93.5 \\
92.0 \\
90.3 \\
87.7 \\
85.5 \\
85.8 \\
85.8 \\
87.3 \\
87.0 \\
86.9\end{array}$ & $\begin{array}{l}71.0 \\
70.3 \\
71.5 \\
71.7 \\
72.6 \\
74.1 \\
71.0 \\
71.5 \\
71.8 \\
71.5 \\
70.5 \\
69.9\end{array}$ & $\begin{array}{l}85.4 \\
86.0 \\
76.4 \\
76.0 \\
75.7 \\
79.0 \\
86.7 \\
81.9 \\
82.2 \\
82.8 \\
80.2 \\
77.2\end{array}$ & $\begin{array}{r}107.5 \\
149.0 \\
144.5 \\
151.3 \\
160.2 \\
105.0 \\
36.3 \\
31.4 \\
42.5 \\
107.0 \\
130.3 \\
158.5\end{array}$ & $\begin{array}{r}1.4 \\
0.3 \\
5.5 \\
6.3 \\
6.7 \\
8.3 \\
14.1 \\
12.9 \\
8.3 \\
7.2 \\
6.9 \\
0.2\end{array}$ & $\begin{array}{r}1.0 \\
0.5 \\
7.5 \\
12.0 \\
14.5 \\
16.0 \\
21.0 \\
24.5 \\
21.5 \\
16.5 \\
10.0 \\
0.5\end{array}$ \\
\hline
\end{tabular}

light and that it is not convectional, as it is in many tropical lands. This is probably due to the influence of the Cameroon Mountain on the prevailing wet winds blowing in off the Atlantic ocean (38).

Breaking the year down in a wet and a dry half, it appears that the wet months (June to November inclusive) contribute most to the correlation $(r=-0.8)$, whereas there is no significant relationship during the period December to May inclusive $(r=-0.4)$. It is evident that there is a distinct difference between these two periods, convectional rains occurring in the dry but not in the wet season. It is also obvious that, owing to the prevailing climatic conditions, the standards to be set to the suitability of a soil for growing perennial crops should be proportionally higher in respect of its drainage in the rainy season and its waterholding capacity in the dry season (25), than would be the case under conditions of a more favourable distribution of both rain and sunshine.

\section{CHAPTER 3}

\section{THE LANDSCAPES AND SOILS OF THE LOWER SLOPES OF THE CAMEROON MOUNTAIN ABOVE THE 300' CONTOUR LINE}

Little is known about the soils of the Southern Cameroons and still less about their use capabilities.

VINE(50) distinguished five main soil units for the whole of the Southern Cameroons and, excluding the saline mangrove soils along the coast, only one main soil group in the area surrounding the Cameroon Mountain range. The latter soil group was described as a brown, friable and cloddy clay formed from volcanic rocks, chiefly basalt, around the Cameroon Mountain, Mount Kupe and Kumba.

EDELMAN and HASSELO (17) observed at least one more main soil unit in the area at the foot of the eastern and southeastern slopes of the Cameroon Mountain, which will be shown (cf. chapter 4) to be confined to the area situated below the $300^{\prime}$ contour line.

The landscapes and soils of the eastern side of the mountain were analysed by means of stereoscopic interpretation of aerial photographs by vaN Es (19). The produced photoanalytical map (scale 1:100,000) was revised by the author and where necessary controlled in the field. 
KRENKeL (33) and Gèze (21) described the geological formation of the Cameroon Mountain and HASSELo and Swalbrick (30) described the eruption of 1959.

There appeared to be a close relationship between the landscapes and the age of the soils of volcanic origin: generally the more broken the land, the older their soils, the younger volcanic deposits having levelled the more broken landscape of old volcanic origin. Consequently, both the landscapes and the soils can be divided into two main groups: (A) the old volcanic and (B) the young volcanic group.

\section{A. THE OLD VOLCANIC LANDSCAPE AND SOILS}

The greater part of the old volcanic landscape consists of a rectangularly shaped area in the extreme southern part of the country, the so called Mabeta area. It covers about 70 square miles $\left(11 \frac{1}{2} \times 6\right.$ miles $)$ and extends from sea level in the south up to $1900 \mathrm{ft}$. above M. S. L. (mean sea level) in the north. The land is very broken and is characterized by valleys, some of them $700^{\prime}$ deep, running from N.W. or W. to S.E. or E respectively. The valleys situated below $300 \mathrm{ft}$. above M. S. L. are rather wide (up to one mile), level and $U$-shaped. The valleys above $300^{\prime}$ are more $\mathrm{V}$-shaped, narrower and more irregularly shaped, their width showing large and irregular variations.

The second area of old volcanic origin borders the Tiko plain in the N.W., and the Mungo and M'Pundu areas in the W. It is also very broken up, but it is not characterised by wide valleys running parallel to each other (except the Koke river valley below. the $300^{\prime}$ contour line, $\mathrm{cf}$. chapter 2).

The third area of old volcanic origin is occupied by the extinguished volcano of the Small Cameroon Mountain (altitude 5625'), which is considered to be the site, where volcanic activity first appeared (30) in the Tertiary era. Subsequent eruptions N.N.E. of it, which led to the formation of the Cameroon Mountain proper, produced volcanic flows, which covered the lower slopes of the Small Cameroon Mountain and the area east of it towards the Mabeta area.

The presence of relic craters consisting of reddish weathered material (cf. paragraph C), form the only conspicuous indication of a probable connection between the Small Cameroon Mountain and the Mabeta area. These outcrops are situated in lines running from W. or N.N.W. to E. or S.S.E. respectively, hence in the same direction as the ridges and valleys of Mabeta, but almost perpendicular to the main eruption axis of West Africa. This axis extends from the islands Annoton, Sao Thomé, Principe and Fernando Poo in the Atlantic Ocean via the Cameroon Mountain range to Lake Chad in the north at the southern boundary of the Sahara desert (see figure 1).

NICKLÉs (36) described it as follows: "Deux directions semblent prédominer, identiques à celles qui ont été mises en évidence au Gabon, l'une parallèle au tracé des grandes cassures indiquées par B. Gèze (21) de part et d'autre du Mont Cameroun, soit Sud-Ouest Nord-Est, la seconde grossièrement perpendiculaire à la première soit SudEst Nord-Ouest. Nous soulignerons la concordance que montrent les éléments principaux du réseau fluvial avec ces directions, en ce qui concerne le Wouri et ses affluents."

The Wouri river (cf. chapter 2 D) runs parallel to and east of the Mungo river.

It would seem probable, therefore, that the first volcanic activity, i.e. prior to the formation of the Cameroon Mountain proper, took place along an axis perpendicular to the present one, the main centre of it being the Small Cameroon Mountain. It would also explain the main direction and the marked parallelity of the valleys in the old volcanic area of Mabeta.

Interference of huge volcanic flows, both of Tertiary and Quaternary age (cf. chapters $2 \mathrm{~B}$ and $\mathrm{D}$ ) in the old volcanic hinterland of the Mungo area and the absence of large wide valleys, as in the Mabeta area, prevent easy recognition of a similar syste- 
matic pattern in the topography. The upper courses of the Mondoni river (cf. chapter $2 \mathrm{~B}$ ) and the Essoasso river, situated just outside the volcanic part of the Tiko plain (cf. table 8) and their tributaries show a river system that conforms to these two main directions and to that of the Wouri river system in the Cameroun Republic (36).

Outside these three main areas of old volcanic origin, relics of the old volcanic landscape are apparent only in the form of relic craters or outcrops, described previously (cf. chapter 2) as pre-Quaternary irruptions in a still older landscape of Tertiary or Precambrian origin and in certain characteristics of the topography of the present landscape.

Outcrops of old volcanic age occur predominantly in the area northeast of Ekona extending down into the lower lying areas of Meanja and M'Pundu, in the Tiko plain, particularly the northeastern half of it, in the West Coast area, i.e. - between the Mabeta area and the Small Cameroon Mountain, and southwest of Buea. Often they can be connected with each other by a line running almost perpendicular to the S.W.N.E. eruption axis of the Cameroon Mountain, hence from N.W. to S.E.

In anticipation of the discussion of the effect of alluvial action on the landscapes below the $300^{\prime}$ contour line, it is of interest to mention that KRENKEL (33) found strongly weathered and brittle basalt tuffs partly formed as sea or fresh water deposits near Debunscha on the southern slopes of the Small Cameroon Mountain at an altitude of ca. $800^{\prime}$ above the present sea level. These slopes were not covered by more recent flows from the Cameroon Mountain. In agreement with it, markedly level plateaux, in the form of wide valley floors, and interruptions of the steep slopes of outcrops by level or less sloping parts were observed at this same altitude of $800^{\prime}$ in the old volcanic areas of Mabeta and Mungo. With regards to the Mabeta valleys, the southern three main valleys are situated below $300^{\prime}$ and will, therefore, be discussed in the next chapter as part of the soils situated below $300^{\prime}$ above M. S. L. The next northern valley, the so called Moliwe valley, which is "open" at both ends, will be dealt with in the next paragraph on the young volcanic soils and landscapes. The most northern valley is a confluence of three smaller valleys. The southern two are situated between $700^{\prime}$ and $800^{\prime}$ above M.S.L. i.e. the level of the $800^{\prime}$ plateau. The most northern one lies between $1000^{\prime}$ and $1100^{\prime}$ above M.S.L.. This level was related with the presence of another plateau. At closer examination, flat or slightly sloping plateaux were indeed observed at the latter level in the Mungo area and on the slopes of the relic volcanoes in the West Coast area. It even appeared possible to form two planes at ca. $800^{\prime}$ and $1100^{\prime}$ respectively by joining the crests of the hills in the Mabeta and the West Coast areas. In the M'Pundu area, the land rises steeply from $300^{\prime}$ to $800^{\prime}$, whereafter it becomes sloping or even level. It could not have been due to younger volcanic deposits having had a levelling effect, because the soils consist of reddish weathered stiff clays full of lateritic concretions so characteristic for their old volcanic origin.

The $800^{\prime}$ and $1100^{\prime}$ levels were not investigated in detail, as was done in the areas below the $300^{\prime}$ contour line with the $120^{\prime}, 220^{\prime}$ and $300^{\prime}$ plateaux or thresholds described in the previous chapter, so that they cannot be claimed to be the only levels of this kind. It is tempting, however, to relate their consistent occurrence at these altitudes to ancient sea shore levels, as already suggested by KRENKEL (33) with regard to the deposits on the Small Cameroon Mountain at $800^{\prime}$ above M.S.L.

Additional evidence for these plateaux being old sea shores was provided by the occurrence of patches of deposits of the yellowish brown (10 YR), quartz containing sandy clays, which were shown to be so typical for the non-volcanic part of the Tiko plain and the M'Pundu-Meanja region. They were not infrequently encountered at these two levels, conspicuously contrasting with the red (2.5 to 5 YR) clays of the old 
volcanic landscape, which moreover do not contain quartz. The most probable explanation for their occurrence at these altitudes on level ground would, therefore, be that they were water laid.

These distinct marks in the topography appeared not to be confined to the old volcanic landscape, but are still apparent, although often not so marked, in the young volcanic landscape (cf. graph. 1).

A description of a typical profile of an old volcanic soil is given in table 5 , in paragraph $3 \mathrm{C}$.

\section{B. THE Young VolCANIC LANDSCAPE AND SOILS}

The remainder and the greater part of the land under consideration between $300^{\prime}$ and $4000^{\prime}$ above M.S.L. on the eastern slopes of the Cameroon Mountain between the Small Cameroon Mountain in the west and the line running E-W along the northern boundary of the Meanja area, is of younger volcanic, i.e. predominantly quaternary, origin.

The influence of the underlying Tertiary landscape on the topography of the present landscape is often still apparent, for instance when ascending from the volcanic part of the Tiko plain and from the West Coast area in a northwestern and northern direction respectively. In the former area, the land above the $300^{\prime}$ contour line rises successively rather steeply (up to approximately $1100^{\prime}$ ), less steeply (to $1500^{\prime}$ ), steeper again (2000'), whereafter up to $3000^{\prime}$ it is at first rather flat and then rather steep, i.e. in the Buea area, but not as steep as outside the latter area. A similar succession sloping-steep-slopingsteep to $800^{\prime}-1100^{\prime}-2000^{\prime}$ and higher up respectively, though over a shorter distance, in the West Coast area, enabled another comparison to be made between the old and young volcanic landscapes.

Whereas in the old volcanic areas the width of the comparatively flat terraces covers a certain interval in altitude in such a way that the lower end is at $700^{\prime}$ for a terrace situated between $700^{\prime}$ and $800^{\prime}$ above M.S.L. or $1000^{\prime}$ for a terrace situated between $1000^{\prime}$ and $1100^{\prime}$ above M.S.L., the transition from a corresponding slope index to another in the young volcanic area is situated $100^{\prime}$ higher, hence for instance at $800^{\prime}$ instead of $700^{\prime}, 1100^{\prime}$ instead of $1000^{\prime}$ and $2000^{\prime}$ instead of $1900^{\prime}$. This difference of $100^{\prime}$, in other words the shift of a particular slope index from a certain altitude in the old volcanic area to a $100^{\prime}$ higher altitude in the young volcanic area, considered to be underlain by an old volcanic landscape with the same characteristics, would seem to indicate that the depth of the young volcanic deposits is of the order of $100^{\prime}$. This depth of deposit corresponds with that of the 1959 lava flow, when it reached a more level part in the Ekona area (30) and with the few available sub surface data. These observations suggest that the valleys in the old volcanic crust in the West Coast area, and perhaps more in general the entire eastern side of the Cameroon Mountain, have been covered by one layer of volcanic flows only. An exception to this generalized picture will be dealt with later, when the Buea area is discussed.

As from $2000^{\prime}$ above M.S.L. the land slopes up very steeply, the major exception being again the Buea area where the steep slope begins at $3000^{\prime}$ above M.S.L. At the latter altitude the steep slope up to the crest of the mountain shows another plateau, recognizable by a chain of villages. It is the most elevated inhabited strip of land all along the eastern slope of the mountain. The reasons for it being just there, are apart from it being level ground, the presence of the most elevated and last spring line and the absence of running water above this altitude, except again above Buea, where springs and running water are found up to an altitude of $6000^{\prime}$.

The explanation for the plateau at $3000^{\prime}$ above M.S.L. was given by Gèze (21), who 
distinguished three phases in the formation of the Cameroon Mountain. The inner part consists of a series of old basalts ("la série noire inférieure"), weathered to laterites and rising up to $3000^{\prime} \mathrm{ft}$. Except for several outcrops near Buea, its presence is not apparent until lower down at about $1900^{\prime}$, i.e. the upper part of the Mabeta series.

The Small Cameroon Mountain (altitude 5625') stands isolated from it, is probably older and consists of different rocks (leucite and nepheline bearing-rocks). The youngest phase, consisting of recent basalts ("la série noire supérieure"), covers the whole complex above $2000^{\prime}$ up to the summit $\left(13,500^{\prime}\right.$ ), also the middle phase, ("la série blanche", named after the colour of its rocks: phonolite and trachyte), whose presence is related to another break in the slope, i.e. at $9000^{\prime}$. This rupture is considered to be due to the difference in fluidity of its rocks.

In the light of this, it is not surprising to find at $3000^{\prime}$ a spring line. For, young volcanic deposits are very permeable for water and are too young to have formed weathering horizons impenetrable for water. All the rain water falling on the slopes of the mountain will readily drain into the soil and only then come near to the surface, where there is a break in the slope and at the same time the subsoil contains water impermeable layers, in casu the old volcanic lateritic clays. The majority of the rivers rising from these springs are seasonal, carrying water in the rainy season only. Hence, a repetition of the conditions, which caused the water to soak away rapidly into the soil and to run off below soil level above the $3000^{\prime}$ plateau.

It is reasonable to assume that the old volcanic landscape below $3000^{\prime}$ had a similar appearance before it was covered with young volcanic efflata as is still evident in the non-covered area of Mabeta, consisting of a sequence of ridges and deep valleys. The latter were shown to run almost perpendicular to the main eruption axis of the Cameroon Mountain, so that the first younger volcanic flows, coming down from the mountain, must have followed these valleys, which, moreover, were more or less parallel to the course of the flows above $3000^{\prime}$. Careful examination of the area below $3000^{\prime}$ revealed that there must have been a slight deviation in the direction of the valleys as compared with that of the slope of the mountain above $3000^{\prime}$, especially below $2000^{\prime}$, hence similar to the slight deviation observed in respect of the Mabeta valleys. It was for instance, clearly demonstrated by the slight deviation of the course of the rivers and of the lava flows of 1908 and 1959 between $2000^{\prime}$ and $3000^{\prime}$ above M.S.L., i.e. changing from southeast above to east below this level.

In order to be able to reconstruct the sequence of events in the beginning of the younger, i.e. second and third, phases of volcanic activity, it is necessary to discuss the different types of volcanic deposits. Three types of volcanic deposits can be distinguished (15): $a$. volcanic ash, $b$. mudflows and $c$. lava flows.

a. Volcanic ash soils in the sense of stratified aeolian deposits.

b. Mudflows, which are formed after ash eruptions, when heavy rains transport the loose material from bare slopes into the valleys and downwards. The slopes may have been bare before the eruption or may have become bare during the eruption as a result of hot ash burning the vegetation. The loose material consists of the fresh ash deposits, but also of any loose material that the mudflow may grub up during its flow downwards. A mudstream carries large boulders with it, which ultimately will block it. Usually, the front of a mudflow consists of a pile of rocks. The mud is thixotropic and once it has come to a standstill will grow stiff, releasing its water. The latter, often replenished with groundwater attracted by the valley like before it was filled up with mud, will come to the surface at the bottom of the front of the mudflow. It often results in the formation of springs at this point, frequently combined with little swamps, owing to the excavating action of the large amounts of water released after 


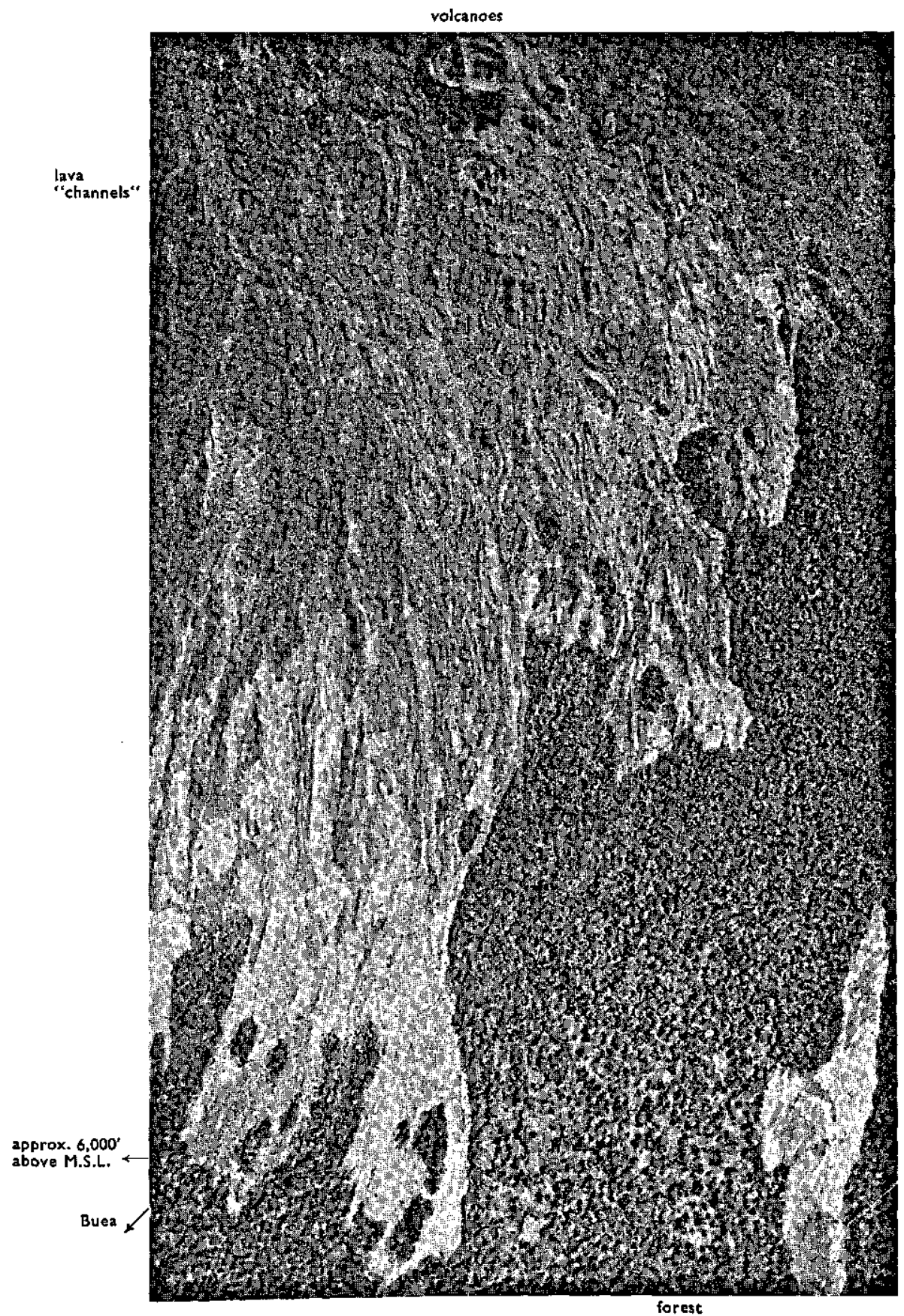

Plate 1. (scale 1:44,000) - Lava "channels" 
the flow came to a standstill. Such springs and swamps in a young volcanic area can, therefore, be often associated with fronts of mudflows and as regards the springs also with lava flows, though less frequently.

It is obvious that a mudflow, reaching speeds of 20 to 30 miles per hours, forms deposits which are not stratified, and that, after the excess of water has been released, the middle part of it or generally where it is at its deepest, will shrink most and consequently sink deeper than its sides. Ultimately, it will have a concave form and when rivers are formed afterwards, they will run in the middle of the mudflow deposit. Usually, it is only near the rocky front of a mudflow deposit, that rivers are forced off the middle part of it, resulting in an often peculiar bend in the course of the river. Mudflows, as distinct from lava flows, always spread fan-wise and soon come to a standstill when they reach level land.

c. Lava flows, like mudflows, follow existing valleys. It was observed, however, (30) during the 1959 eruption of the Cameroon Mountain that lava can pile up high above the level of the surrounding land, for instance when the valleys are too small to contain it or when a less precipituous part of the landscape is crossed. Consequently, the landscape is topographically reversed, i.e. valleys becoming ridges and conversely. Although it was observed (30) that the surface of a lave flow can be very broken, particularly when crossing level ground, it did not explain the observation of rivers often running on top of and in the middle of old lava streams.

Stereoscopic examination of the slopes of the mountain above the forest line showed that the sides of old lava flows were always higher than their middle part, as if they were embanked rivers or irrigation ditches. It indicated a process principally the same as described for mudflows, in this case the lower middle part being due to contraction of the rocks during cooling down, a process, which may take up to 10 years (35). The rocks at the sides and front of a lava stream cool down more quickly, particularly those which were ejected first and travelled the larger distance, than the rocks in the centre. Assuming the lava surface to be level at the time the eruption comes to an end, the hottest and most insulated middle part of the lava will contract most and flow longest, resulting in the formation of lava "channels". An aerial view of the bare slopes of the mountain gives the impression of a railway station with many rail tracks. Each rail track, i.e. lava flow, can be followed from its origin to where it disappears in the forests lower down on the slopes (cf. plate No. 1).

Referring back now to the young volcanic landscape at about $2000^{\prime}$ above M.S.L., the old volcanic Mabeta area must have formed an unsurmountable barrier to the descending volcanic flows, except at its extreme northeastern point, where presently the Tole river runs, two small inroads into the Ombe river valley at 1900', and the western outlet of the Moliwe river valley. Consequently, the western part of the latter valley, although undoubtedly of old volcanic origin, was covered with young volcanic material.

Further evidence for the given sequence of events in the physiography was provided by a comparison of the longitudinal profiles of the Ombe river and its tributaries: the Tole and the Moliwe river, with that of the Benoe river, whose course was not affected by the Mabeta landscape (graph 1).

Down to $1900^{\prime}$ above M.S.L. all four rivers are situated in a young volcanic landscape, and have shallow valleys, their longitudinal profiles running almost parallel to each other. The Tole river and particularly the Benoe river show a slightly less steep gradient, because of the previously mentioned exceptional slope index (up to $3000^{\prime}$ ) of the Buea area. Below $1900^{\prime}$ down to $700^{\prime}$, the deeply cut in Ombe river crosses the old volcanic landscape, showing abrupt changes in its gradient at 1900', 1500' and 1100', 


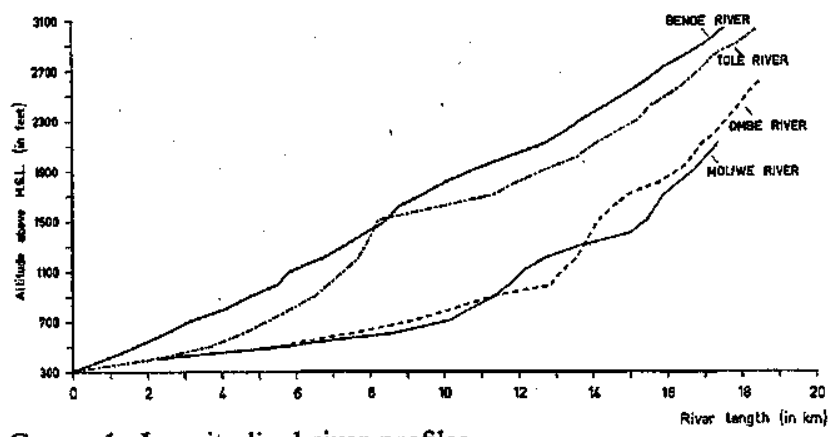

GRAPH 1. Longitudinal river profiles the former and latter altitudes being in accordance with the presence of plateaux in the old volcanic landscape (cf. chapter 3, paragraph 1). At $700^{\prime}$ it enters again the young volcanic soils, which were deposited through the Tole river gorge at the eastern border of the Mabeta series. This gorge in the $800^{\prime}-1100^{\prime}$ escarpment,

which extends up to $1500^{\prime}$, caused the irregularity in the otherwise almost uniform gradient of the Tole river.

The gradient of the Moliwe river, the counterpart of the Tole river at the western boundary of the old volcanic landscape is influenced down to $700^{\prime}$ by recent volcanic flows, which pushed its course straight to the boundary between the young and old soils, and into the Moliwe valley by blocking its former and shorter course down to the Atlantic Ocean at Victoria.

The Benoe river has a particularly uniform gradient, notwithstanding it also crosses the $800^{\prime}-1100^{\prime}$ escarpment by means of a very deep gorge. It was thought to be related to the type of flow by means of which the young volcanic material was deposited and on top of which the Benoe river runs. It was shown previously, that the Buea area formed in several respects an exception to the general pattern of slope gradients. It was considered to be related to a fault, which extends from Buea up to the $9000^{\prime}$ plateau: Extending it further by an imaginary line over the summit of the mountain and down again along the western slope, a huge gorge (3000' to $6000^{\prime}$ deep) becomes apparent as from the $9000^{\prime}$ plateau and down to an altitude of about $3000^{\prime}$. It would seem extremely likely that these faults, which can be connected by a straight line, were created by one and the same force, at the time of the second phase of volcanic activity, ("la série blanche"), between the old and young volcanic phase of tertiary and quaternary origin respectively. The Buea gorge, however, is not very conspicuous because it was filled up almost completely by subsequent efflata.

Undoubtedly, lava flows played an important part in filling it up, as may be inferred from the many lava "channels", which, coming down from the top and main crater of the Cameroon Mountain, the Fako, debouch into this gorge at the edge of the $9000^{\prime}$ plateau. Below this edge and as distinct from the surrounding area outside the gorge, the course of only a few can be followed further down. It was found to be due to subsequent mudflows, which covered the lava "channels". The Buea gorge is, indeed, ideally placed for the catchment and formation of mudflows, as it is situated straight under the Fako crater.

The huge amount of material needed to fill it up can be inferred from the depth of the gorge on the western side of the mountain. From the mouth of the Buea gorge at $3000^{\prime}$ above M.S.L. downwards, the mudflows have spread fan-wise, following a course predetermined by the relief pattern of the old volcanic landscape, and covering along its main direction all the land down to the $300^{\prime}$ escarpment and, as will be seen in the next chapter, even the western half of the Tiko plain down to sea level. The amount of material that came down at either side of the Buea gorge in the form of lava and mudflows must have been considerably less, as may be inferred from the distance 
covered by them or alternatively the lowest level reached by them. It is particularly true for the land west of the gorge, where owing to the increasing distance from the Fako, and the rapidly decreasing altitude of the crest of the mountain, resulting in a smaller catchment area for volcanic ash, the area covered by the mudflows is decreasing steadily. In the hinterland of the West Coast area, mudflows have been virtually absent, resulting in much rockier soils than those more to the east. It would moreover, appear to be borne out by the relatively shallow deposit (previously estimated as to be $100^{\prime}$ ) of young volcanic material. In this area there are two very recent lava flows, which according to the age of the forest growing on it, cannot be older than 150 years. Another distinct difference between the areas S.W. and N.E. of the Buea gorge is the lack and abundance respectively of secondary eruption points, with well preserved craters of recent origin.

These observations allowed the interpretation of several other characteristic features of the landscape and futhermore confirmed several locally known but unexplained facts:

a. The least rocky, consequently agriculturally most suitable, soils of young volcanic origin are deposited in the area between southeast and northeast from Buea (cf. chapter 5), and the shallowest soils in the West Coast area.

$b$. The western slopes of the Cameroon Mountain have probably not profited to the same extent from mudfiow deposits, considering the depth of the western gorge, and the abscence of lava channels debouching into it.

It would appear to be borne out by the much greater population density of and the easier access to the eastern slopes of the mountain.

c. The absence of stratified ash deposits on the lower eastern slopes of the Cameroon Mountain, and the observation that the areas covered by rocky soils are in excess of those with less rocky soils, indicated that mudflows played a less important role than lava flows, and that the ejected material was in the form of lava rather than of volcanic ash. It is even very likely that only the Fako crater produced any appreciable amounts of volcanic ash. The latter was borne out by the presence of thick layers of volcanic ash on the Fako plateau at $12000^{\prime}$ above M.S.L..

The eruptions recorded since the second half of the last century $(30,33)$ or those which could be dated back to the first half of it (cf. lava flows of the West Coast area) all originated from secondary vents between $7000^{\prime}$ and $10,000^{\prime}$ above M.S.L. situated along the main N.N.E. eruption axis, and produced mainly lava, the ash deposits being negligible.

$d$. The majority of the rivers of the western slopes shown on the excellent topographic map (scale $1: 200,000$ ) of the Cameroon Mountain, produced by HASSERT (31) as early as 1908 , bends at an altitude of between $3000^{\prime}$ and $2000^{\prime}$ from a northwestern to a more western course, indicating a similar effect of the old volcanic on the present landscape as previously demonstrated for the eastern slopes.

$e$. The presence of springs and running water above the most elevated spring line at $3000^{\prime}$ above M.S.L. is confined, hence related, to the area occupied by the Buea gorge. $f$. The longitudinal profile of the Benoe river, rising in the Buea gorge was shown to have a very uniform gradient, even at the crossing at the $800^{\prime}-1100^{\prime}$ escarpment. It is related to the fact that its course follows the direction of a recent mudflow. For, the force exercised by the mudflows on the floor of the existing (cf. [g]) river valleys in the $800^{\prime}-1100^{\prime}$ escarpment, must have had a levelling effect on it. The nearer to the centre of the main direction of the mudflows, the larger the amounts that passed, the greater the force and the smoother (cf. difference between Tole and Benoe river gorges) the surface, hence also the river gradient. With regard to the latter, there is also a time 
factor involved in it, i.e. the more recent the mudflow, the smoother the river gradient, particularly at crossings like the $800^{\prime}-1100^{\prime}$ escarpment. It will be demonstrated in the next chapter that the Benoe mudflow is indeed of a rather recent age. It is also indicated by the slightly but distinctly convex form of the Benoe river profile between $2000^{\prime}$ and $1500^{\prime}$ above M.S.L. (graph 1), where owing to the crossing of a relatively level part of the landscape, the time has been too short for the more slowly running river to cut itself deeper into its shallow valley. It was for instance not the case with a rivulet running parallel with and west of the Benoe river on an older mud deposit at a distance of less than 300 yards, and whose valley between the $1800^{\prime}$ and $2000^{\prime}$ contour lines is between $40^{\prime}$ and $60^{\prime}$ deep.

$g$. Both the $800^{\prime}-1100^{\prime}$ and the $300^{\prime}$ escarpments are characterized by deep river gorges. It may be inferred from the observation that these gorges were also present in the $300^{\prime}$ escarpment bordering the eastern half of the Tiko plain, which was not covered by young volcanic material, that they were in existence before the mudflows of the third phase of volcanic activity were formed. It would appear therefore, that the steep escarpment between $800^{\prime}$ and $1100^{\prime}$ at either side of the Benoe river gorge, which in places rises as much as $200^{\prime}$ over a distance of less than 150 yards, is not necessarily of quaternary origin. It is more likely to have originated in the second phase of volcanic activity, when the Buea gorge came into existence, for the following reasons:

1. The escarpment is confined to and situated in the area of the main direction of the flows originating from the Buea gorge;

2. the flows came to a standstill on one of the level terraces of the old volcanic landscape;

3. going downwards along the road cut out along the front of the escarpment, the soil colour gets a gradually more reddish tinge, however not as red as that of the old volcanic deposits. Except in places where thin layers of dark brown (10 YR 3/3) mudflow material of young volcanic age covered it, the colour at the top of the escarpment is in the brown to dark brown 7.5 YR 5/4 to 4/4 range, lower down gradually changing to reddish brown (5 YR 4/4 to 4/3). It would concur with the relation between age of the soil and the intensity of laterization as observed by GÈze (21) (cf. chapter 2E-soils), and with the observation of the characteristicly grey to white colour of the rocks ("la Série blanche": trachyte and phonolite).

$h$. The depth of the layers deposited during the second phase of volcanic activity were estimated from the height of the escarpment as to be at least $300^{\prime}$. For, if at all, the last phase of volcanic activity, i.e. the mudflows of that period, deposited only a thin layer on top of the escarpment, the remainder having followed the deep gorges down to lower levels. The latter may also be inferred from the shallow deposits, if present at all, encountered in the almost level land eastwards of the Benoe river escarpment towards the broken Mungo landscape of old volcanic origin.

This section, called N'Sonne Moliwe, is not characterized by river gorges and was shown previously (cf. chapter 2 ) to contain a range of extinct volcanoes, grouped along a S.S.W.-N.N.E. axis, originating in the Benoe crater in the Tiko plain. In the light of the available evidence, it would, therefore, appear most likely that these craters were formed during the second phase of volcanic activity.

Assuming that most of the volcanic flows of the second phase of volcanic activity originated in the Buea gorge, then their dispersion lower down must have been confined to the area between northeast and southeast from Buea. This associated with a possible formation of escarpments on level terraces of the underlying old volcanic landscape, as may be inferred from the $800^{\prime}-1100^{\prime}$ Benoe river escarpment, imme- 
diately raised the question of the origin of the two escarpments northeast of Ekona, situated between $400^{\prime}$ and $600^{\prime}$, and $800^{\prime}$ and $1000^{\prime}$ above M.S.L. respectively. Deposits of the characteristic "white" rocks were indeed discovered on top of the higher escarpment along the main road from Ekona to Kumba, which were overlain by two feet only of young, darkly coloured volcanic material. At this site there is quarry used for digging material for road making. Locally, these rocks are known as ground stone. The fact, that it can be broken very easily explains its attractive qualities as surfacing material for roads. This knowledge will become extremely useful for a detailed soil survey of the volcanic areas, because the name ground stone, hence its occurrence, is locally well known.

There are two other interesting aspects to it: firstly, its deposit as a (lava) flow involves that once ground stone is found in one place, the probable continuation of the lava stream to lower and higher elevations can without much difficulty be traced on the aerial photographs or eventually topographical maps. Where the land is cultivated, particularly with a sensitive crop like bananas, the relatively poor development of the crop, and in the case of Panama Disease susceptible Gros Michel bananas, also the high disease incidence, will immediately indicate the site, length and width of these volcanic flows of the second phase of volcanic activity, and may even enable an estimate of the depth of the young volcanic material by which they are overlain. An excellent example of it on level land is found in the Molyko area between Ekona and Buea. The second aspect is the gorge on the western slope of the mountain. This gorge, especially its sides, shows up on the aerial photographs as an extremely white background covered with black stripes running down from the top of the mountain in straight lines. In the light of the forgoing, one would be inclined to relate the former colour to the white colour of the parent material of the second volcanic phase and the black stripes to subsequent and more recent flows of the black basalt phase.

\section{THE VOLCANIC SOILS}

Three main groups of soils in the volcanic area may be distinguished. They are related to the three phases of volcanic activity, discussed in the previous paragraph. The most obvious difference between these three soil groups is their colour, which was shown by GĖzE (21) to be related to the degree of laterization and the age of the soil.

In terms of the Munsell colour scheme the oldest volcanic soils are in the yellowish red $(5 \mathrm{YR} 5 / 8$ to $6 / 8)$ to red $(2.5 \mathrm{YR} 4 / 8$ to $5 / 8)$ range, the next younger - originating from the second phase of volcanic activity - are in the yellowish red 7.5 YR (5/4 to 4/4) to red 5 YR (4/4 to 4/3) range, while the deposits of the lastvol canic phase are all in the very dark brown to yellowish brown 10 YR (2/2 to 5/5) colour range.

In the profile descriptions of tables 5 and 6, typical examples are given of the former and the latter only, the soils of the intermediate phase being of no consequence in respect of surface area covered, although they may have a markedly unfavourable influence on the rooting depth, hence suitability, of a soil, underlain by them at shallow depth. It is particularly noticeable in the N'Sonne Moliwe area and in a strip of land in the Molyko area. 


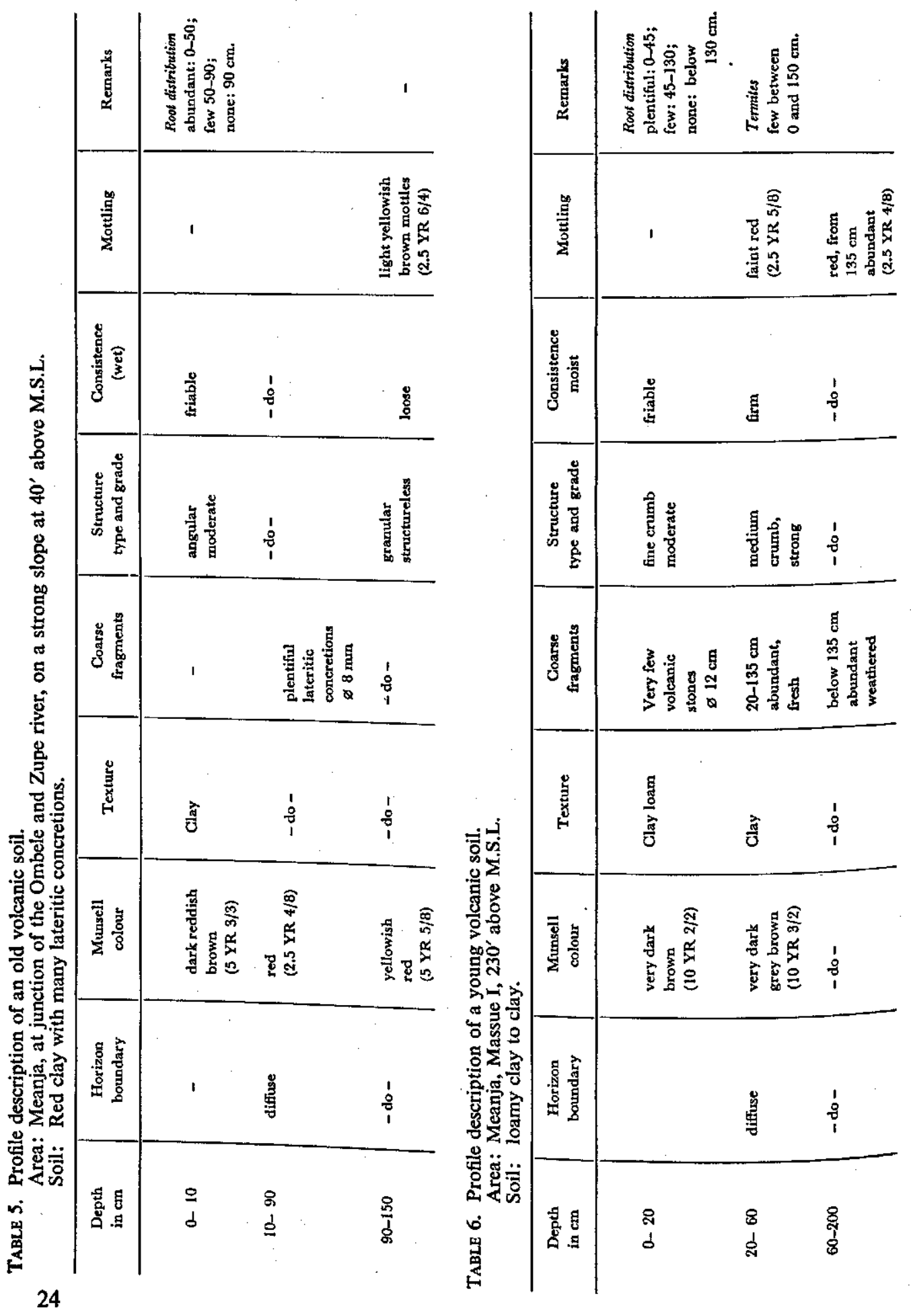




\section{Chapter 4}

\section{THE SOILS OF THE LOWER SLOPES OF THE CAMEROON MOUNTAIN BELOW THE $300^{\prime}$ CONTOUR LINE}

The land lying below the $300^{\prime}$ contour line is characterized by a coastal plain landscape consisting of mangroves and of alluvial soils.

Riverine alluvial soils of Quaternary age are situated along and mainly at the delta of the Mungo river. The remaining and major part of the land lying below $300^{\prime}$ above M.S.L. is occupied by alluvial soils considered to be of marine origin.

In terms of geological age, there are three types of marine deposits. Marine sediments from before the Tertiary period are the oldest known to occur in Nigeria (50) and the Cameroons $(33,36)$. Strongly weathered and brittle basalt tuffs of Tertiary age were found by KRENKEL (33) on the lower slopes of the Small Cameroon Mountain at $800^{\prime}$ above M.S.L. The occurrence of plateaux at the latter level and at $1100^{\prime}$ and $1500^{\prime}$ above M.S.L. was discussed in chapter 3, also in view of a possible relationship with ancient sea shore levels.

Finally, there are the younger coastal deposits containing plant debris of oil and raphia palms, hence the present day type of vegetation.

The marine deposits along the southeastern coast (Tiko plain) and further inland along the Mungo river (the Mungo, M'Pundu and Meanja areas) were mainly built up from material derived from cristalline rocks from the hinterland. This cristalline basement was shown to be of Precambrian formation (chapter 2) and to consist of gneisses, schists and granites. The boundary is characterized by an escarpment of tectonical origin, but it is interrupted where the still active Cameroons Mountain emerged in the latter half of the Tertiary period. The marine deposits will be shown to be of a rather recent origin. In that case, it is reasonable to assume that where they were laid in or near areas of volcanic activity, admixture of volcanic material must have taken place. This was indeed evident in the southwestern part of the Tiko plain, which was covered with volcanic material of a rather recent origin, consisting of more or less weathered basalt fragments. It was less obvious in the areas northeast of Ekona, where volcanic deposits of a much older origin weathered down to latosols. More knowledge about the use-capabilities (cf. chapter 5) of these marine deposits would be of great interest and of considerable commercial value to the country, also because these soils cover most of the level land and are situated near the main ports of embarkation of agricultural produce.

\section{A. SURveYS}

\section{Photoanalysis}

The aerial photographs and the photomosaics produced from them clearly indicate the old marine hydrographic system, which with its rounded pattern could easily be discerned from a riverine alluvial deposit. The system and pattern of the creeks which are evident in the present mangroves, are also visible in the adjacent higher lying land up to $100 \mathrm{ft}$. especially in undisturbed forest land. In the areas cultivated with perennial crops at M'Pundu and Meanja, especially at altitudes of between $120^{\prime}$ and $220^{\prime}$ the same drainage pattern i.e. particular to coastal areas, was noticed though more difficultiy.

Another feature, which could be clearly distinguished on the photographs was the levelling effect of the sea. It extends up to an altitude of $300^{\prime}$ but is more prominent in land lying below the $220^{\prime}$ contour line. 


\section{Ground survey}

Since the initiation of the soil survey in 1957 , more than 20,000 acres were surveyed in detail and the results compiled in maps with a scale of $1: 6,500$, mainly in the Tiko and Ekona areas, between sea level and $300^{\prime}$ altitude.

A grid of one boring per hectare with the help of subsequent stereoscopic analysis of the aerial photographs allowed the production of soil maps of as large a scale as of between $1: 5,000$ and 10,000 .

From these surveys it became very soon evident that the marine soils were deposited rather recently. Their profiles are young and scarcely developed as will be seen from the profile descriptions in table 7.

TABLE 7. Soil profile descriptions

I

Marine soil: not volcanic.

Location: Ekona - Massue; Elevation: 220'

\begin{tabular}{|c|c|c|c|c|}
\hline $\begin{array}{l}\text { Depth } \\
\text { in cms. }\end{array}$ & Texture & $\underset{\text { boundaries }}{\text { Horizon }}$ & Munsell Colour & Structure Type \& Grade \\
\hline $0-18$ & Loamy sand & - & $\begin{array}{l}\text { Very dark grey brown } \\
10 \mathrm{YR} 3 / 2\end{array}$ & Granular, structureless \\
\hline $18-35$ & Loamy sand & Gradual & $\begin{array}{l}\text { Very dark brown } \\
10 \text { YR } 2 / 2\end{array}$ & Fine crumb, moderate \\
\hline $35-60$ & Very sandy clay & Abrupt & $\begin{array}{l}\text { Dark yellowish brown } \\
10 \text { YR } 3 / 4\end{array}$ & $\begin{array}{l}\text { Medium crumb, } \\
\text { moderate }\end{array}$ \\
\hline $60-180$ & Sandy clay & Diffuse & $\begin{array}{l}\text { Yellowish brown } \\
10 \text { YR } 5 / 5\end{array}$ & Coarse crumb, strong \\
\hline
\end{tabular}

II

Marine soil: volcanic parent material

Location: Tiko - Sonne. Elevation: 100'

\begin{tabular}{|c|c|c|c|c|}
\hline $\begin{array}{l}\text { Depth } \\
\text { in cms. }\end{array}$ & Texture & $\begin{array}{c}\text { Horizon } \\
\text { boundaries }\end{array}$ & Munsell Colour & Structure Type \& Grade \\
\hline $0-20$ & Sandy loam & Diffuse & Dark brown 10 YR $3 / 4$ & Very fine crumbs \\
\hline $20-55$ & $\begin{array}{l}\text { Clay-fine sandy } \\
\text { clay }\end{array}$ & $\begin{array}{l}\text { Smooth } \\
\text { Diffuse } \\
\text { smooth }\end{array}$ & Dark brown 10 YR $3 / 3$ & Subangular blocky \\
\hline $55-85$ & $\begin{array}{l}\text { Clay-fine sandy } \\
\text { clay }\end{array}$ & $\begin{array}{l}\text { Diffuse } \\
\text { smooth }\end{array}$ & Grey brown 10 YR $5 / 2$ & Angular blocky \\
\hline $85-140$ & Sandy clay & Diffuse & Dark grey brown & Medium subangular \\
\hline
\end{tabular}

It was assumed that these marine soils were deposited at high sea levels. In Europe such high sea levels coincide with interglaciation periods. It will be seen from table 7 that the soils of profiles I and II differ in the origin of parent material. Profile II is situated in the southwestern part of the Tiko plain, which is covered with deposits of volcanic origin as distinct from the soils of the northeastern part of the Tiko plain and the areas northeast of Ekona which are derived from material weathered from basement rocks, probably mixed with variable amounts of volcanic material. The deposits in the latter areas contain varying amounts of quartz sand as distinct from the purely volcanic soils, which do not contain quartz sand.

The effect of volcanic material deposited during the period under consideration, that is at high sea levels, on the topography was studied in particular with regard to the 
longitudinal profile, valley depth and course of the rivers. The evidence obtained from it led to the conclusion that there have been different sea levels, i.e. at $300^{\prime}, 220^{\prime}, 120^{\prime}$, and probably $20^{\prime}$ above M.S.L. successively.

\section{B. MaRine PlateauX}

Several aspects of the influence of high sea levels on the physiography of the land were discussed in the preceding pages. Other factors which markedly influence the topography, such as volcanic deposits, were mentioned in chapters 2 and 3.

The interrelationships of these different effects on the topography were studied by means of longitudinal profiles of rivers in an attempt to unravel the succession of the different events and from that the relative age of the different deposits.

\section{River profiles}

The longitudinal profiles of several rivers in the Tiko plain and the M'PunduMeanja area northeast of Ekona indicate large changes in a rather recent geological history.

In table 8 the length of the rivers (in meters) and their tributaries is given at altitude intervals of 20 feet.

TABLE 8. Longitudinal river profiles (meters)

\begin{tabular}{|c|c|c|c|c|c|c|c|c|}
\hline \multirow{3}{*}{$\begin{array}{c}\text { Soils } \\
\text { Altitude } \\
\text { Interval } \\
\text { (in feet) }\end{array}$} & \multicolumn{4}{|c|}{$($ S.W. $\leftarrow)$ Tiko area $(\rightarrow$ N.E.) } & \multicolumn{4}{|c|}{$($ S. $\leftrightarrow$ ) Ekona area $(\rightarrow$ N.) } \\
\hline & \multicolumn{2}{|c|}{ Volcanic } & \multirow{2}{*}{$\begin{array}{c}\begin{array}{c}\text { Transi- } \\
\text { tional }\end{array} \\
\begin{array}{c}\text { Sonne } \\
\text { River }\end{array}\end{array}$} & \multirow{2}{*}{$\begin{array}{c}\begin{array}{c}\text { Non- } \\
\text { Volcanic }\end{array} \\
\begin{array}{c}\text { Essoasso } \\
\text { River }\end{array}\end{array}$} & \multicolumn{2}{|c|}{ Transitional } & \multirow{2}{*}{$\begin{array}{c}\begin{array}{c}\text { Non- } \\
\text { Volcanic }\end{array} \\
\text { Zupe } \\
\text { River }\end{array}$} & \multirow{2}{*}{$\begin{array}{c}\begin{array}{c}\text { Transi- } \\
\text { tional }\end{array} \\
\begin{array}{c}\text { Ombele } \\
\text { River }\end{array}\end{array}$} \\
\hline & $\begin{array}{l}\text { Benoe } \\
\text { River }\end{array}$ & $\begin{array}{l}\text { Ndongo } \\
\text { River }\end{array}$ & & & $\underset{\text { River }}{\text { M'Pundu }}$ & $\begin{array}{l}\text { Malele } \\
\text { River }\end{array}$ & & \\
\hline $0-20$ & 1950 & 1850 & 3300 & 4350 & \multicolumn{4}{|c|}{ Mungo River } \\
\hline $20-40$ & 600 & 1350 & 3150 & 3000 & 3250 & & 1500 & \\
\hline $40-60$ & 700 & 650 & 400 & 2950 & 100 & & 300 & $\begin{array}{r}350 \\
50\end{array}$ \\
\hline $60-80$ & 500 & 950 & 550 & 2700 & 300 & & $\begin{array}{l}250 \\
350\end{array}$ & $\begin{array}{r}50 \\
200\end{array}$ \\
\hline $80-100$ & 550 & 350 & 700 & 100 & $\begin{array}{l}\mathbf{5 5 0} \\
\mathbf{5 5 0}\end{array}$ & & 250 & 1450 \\
\hline $100-120$ & 400 & 200 & 950 & $\begin{array}{l}350 \\
800\end{array}$ & 1250 & & 4600 & 1700 \\
\hline $120-140$ & 250 & 350 & 650 & 250 & 350 & 50 & & 100 \\
\hline $140-160$ & 300 & 300 & $\begin{array}{l}600 \\
300\end{array}$ & 650 & 200 & 2000 & & 50 \\
\hline $160-180$ & 350 & 600 & $\begin{array}{l}300 \\
250\end{array}$ & 450 & 1300 & 0 & & 50 \\
\hline $180-200$ & 200 & 350 & $\begin{array}{l}250 \\
100\end{array}$ & 50 & 1100 & 100 & & 20 \\
\hline $200-220$ & 200 & 200 & $\begin{array}{r}100 \\
50\end{array}$ & 100 & 150 & 400 & & 20 \\
\hline $220-240$ & 250 & 300 & $\begin{array}{l}50 \\
50\end{array}$ & 100 & 500 & 200 & & \\
\hline $240-260$ & 300 & 250 & $\begin{array}{l}50 \\
50\end{array}$ & 150 & 400 & 100 & & \\
\hline $260-280$ & 200 & 200 & $\begin{array}{l}50 \\
50\end{array}$ & 100 & 500 & 800 & & \\
\hline $280-300$ & 200 & $\begin{array}{l}100 \\
150\end{array}$ & $\begin{array}{r}50 \\
150\end{array}$ & 100 & 150 & 250 & & \\
\hline 300 & 350 & & & & & & & \\
\hline
\end{tabular}

It will be seen from table 8 that the six main rivers both at Tiko and Ekona have similar longitudinal profiles, and furthermore, that the gradient of the rivers in the 'Tiko plain is less below about $220^{\prime}$, i.e. the level at which the escarpment bordering the Tiko plain ends. These findings indicate that the rivers have been subjected to a large extent to the same influence from sea level up to the $300^{\prime}$ contour line. This is in line with the observations made on the aerial photographs, i.e. on the leveling effect of the sea.

Correlating the longitudinal profiles of the different rivers up to the $320^{\prime}$ contour 
line, highly significant positive correlation coefficients were found, the agreement being closer between the combinations Essoasso-Ndongo $(r=0.98)$ and M'Pundu-Sonne $(r=0.97)$ than between Ndongo-Sonne $(r=0.82)$ and M'Pundu-Essoasso $(r=0.78)$. The relationship is much less marked in the interval between $0-220^{\prime}$, where a significant correlation was only obtained between the Essoasso and Ndongo rivers. In this respect it is of interest to note that high correlation coefficients were obtained, when the rivers are situated in areas where the soils are entirely of either volcanic or nonvolcanic origin. Combinations of rivers situated in dissimilar areas, such as NdongoSonne and M'Pundu-Essoasso gave lower correlation coefficients. From this, it was concluded that the absence of a relationship below the $220^{\prime}$ line between river profiles in the Tiko plain, except for the Ndongo-Essoasso combination, was due to some interfering action, which did not effect the Ndongo and Essoasso rivers or acted in the same way.

In graphs $2(a$ and $b$ ) and $3(a$ and $b$ ) the longitudinal river profiles are drawn, together

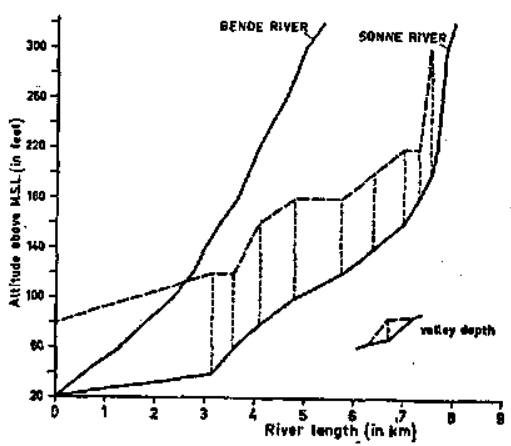

GraPH 2a. Longitudinal river profilesTiko plain

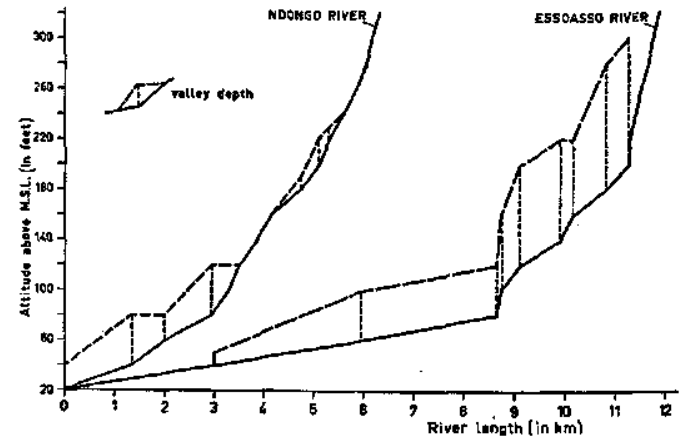

GrAPH 2b. Longitudinal river profiles-Tiko plain

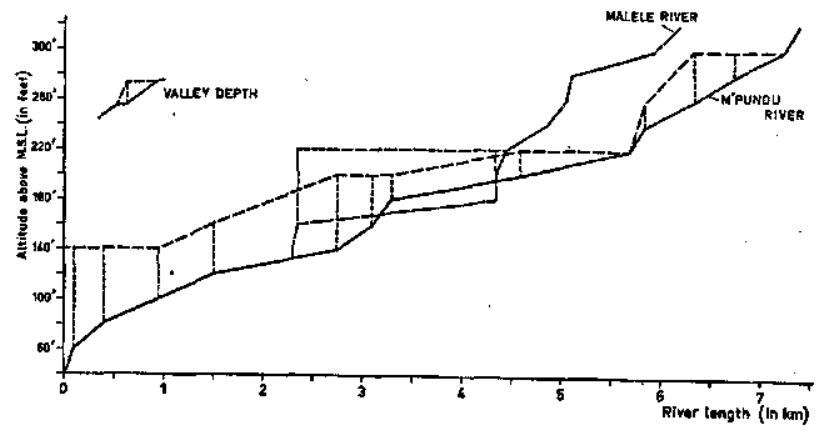

GRAPH 3a. Longitudinal river profiles M'punduMeanja area

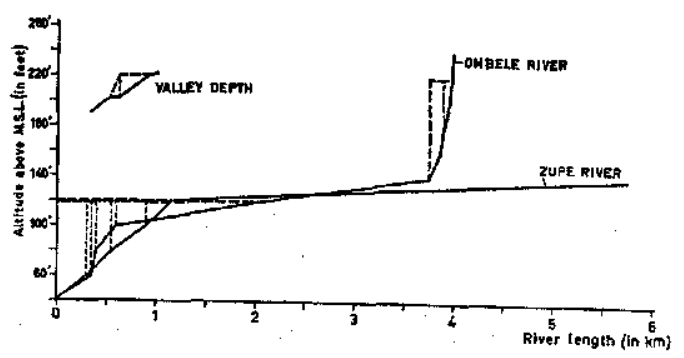

GraPH 3b. Longitidunal river profiles M'punduMeanja area 
with the depth of their valleys, if more than 10 feet deep. They elucidated the as yet unexplained phenomena.

Reverting to the hypothesis of different sea levels and disregarding for the moment the Benoe river, it will be seen that after a gradual increase from sea level to $40^{\prime}$ the river gradient increases in an irregular pattern. All the river bottoms show distinct changes in their slopes at the following approximate altitudes: $120^{\prime}, 220^{\prime}$ and $300^{\prime}$, in other words the supposed levels of the different marine plateaux.

Other distinct changes in gradient were, however, also noticed. For instance, in the case of the Sonne river at $40^{\prime}$ and $200^{\prime}$, of the Essoasso river at $80^{\prime}, 140^{\prime}$ and $200^{\prime}$, of the M'Pundu river at $40^{\prime}, 140^{\prime}$ and $180^{\prime}$. These points do not seem to coincide with the different sea levels. But, if related to the depth of the valleys, it will be seen from the graphs that at these points the level of the surrounding land is that of the different plateaux.

From this, it was concluded that the present river valleys served as creeks at the time of high sea levels. When the sea extended to, for instance, the present $220^{\prime}$ line, these creeks were deepened as a result of tidal action. The depth of the valley bottoms up to a level of $220^{\prime}$ shows this erosive action, naturally dependent on the amount of water carried. It is obvious that where the river (alternatively creek) valleys were deep, the erosive action was greatest, especially at the beach line of the surrounding land. The abrupt changes in the slope of the valley bottom of the Essoasso river, for instance, at $80^{\prime}, 140^{\prime}$ and $200^{\prime}$ are apparently caused by the larger amounts of tidal water that had to be transported and came from the surrounding land when it was submerged to $120^{\prime}$, $220^{\prime}$ and $300^{\prime}$ respectively. The effect of the tidal action on the river bottom is still noticeable further inland, viz. passed the beach line of the surrounding land, until a point where the valley bottom itself crossed the $120^{\prime}, 220^{\prime}$ or $300^{\prime}$ levels.

The nearer the valley bottom came to the sea shore level the shallower it became, as is clearly shown by the river profiles up to $120^{\prime}$ in the Ekona area. The formation of these valleys could therefore be compared with the formation of rias, a ria being a normal valley drowned by a rise of sea-level relative to the land, and that of a marine plateau with a relic ria type of coast line.

Having acquired this knowledge, a number of other outstanding phenomena could also be explained. It will be seen in table 8 that the Essoasso river slopes up relatively little from sea level to the $80^{\prime}$ level as distinct from the $20^{\prime}$ and $40^{\prime}$ levels for the Benoe and the other rivers respectively. This was found to be due to mudflows coming down through a deep gorge in the ridge bordering the Tiko plain, through which the Ndongo river runs (cf. chapter $3 \mathrm{~B}$ ). These mudflows spread fan-wise over the level part of the Tiko plain, thus silting up the Ndongo, and sideways and partly at about the $120^{\prime}$ level, the Sonne and Essoasso rivers. The result was that the Essoasso river was forced into a new bed as from the $120^{\prime}$ level. The silted-up old bed below $120^{\prime}$ could be recognised on the aerial photographs and is still in existence as a $10^{\prime}-20^{\prime}$ deep valley as from the $40^{\prime}$ line downwards in the so called Sonne-Ebondje section. There, the latter valley serves as the main drain for the badly drained, silted up, rather level and saucer like area between the Essoasso and Sonne rivers between the $40^{\prime}$ and $120^{\prime}$ contour lines. In this area several profiles were encountered where the volcanic material was still found to be lying on top of the quartz sand containing marine deposits of non-volcanic origin (cf. table 1, chapter 2). It would appear, therefore, that the mudflows deposited their material when the sea shore had regressed from a higher level down to the $120^{\prime}$ line.

The new river bed of the Essoasso River below $80^{\prime}$ is little cut in, its length longer and its gradient less, also owing to a presently relic, but at that time alive beach formation, which prevented it from running straight into the present mangrove area. This 
explains why the Essoasso river reaching this beach formation and being so near to the mangroves suddenly changes its course from a southeastern to a southwestern direction, i.e. more than 90 degrees, whereas rivers at either side of it, inclusive the old Essoasso river bed, keep their southeastern course straight into the mangroves.

The course of the Sonne river shows the reverse picture of that of the Essoasso. When its old course was blocked up by a mudflow, it formed temporarily a new course which functioned as a creek and which debouched at the $40^{\prime}$ line into the original and still existing part of the bed of the Essoasso below 40'. This new creek course from $100^{\prime}$ down to the $40^{\prime}$ level was silted up again by the sea when it was at its $120^{\prime}$ level and after it had cut back again into the mudflow filled river valley of the Sonne river. The temporary new course of the Sonne creek which ran perpendicular to the present contour lines could be identified on the aerial photographs and could easily be mapped out during the ground survey. These events resulted in the strange phenomenon that the present course of the Sonne river runs with an acute angle, i.e. not perpendicular, to the present contour lines between $40^{\prime}$ and $120^{\prime}$.

This situation is related to a similar phenomenon in the course of the Malele river at Meanja, which runs in a deep valley almost parallel to the contour lines from the $200^{\prime}$ line down to where it empties itself by means of waterfall in the M'Pundu river. The latter river follows a course perpendicular to the present contour lines. The exposed valley walls of the Malele river show from top to bottom firstly a layer of marine deposits, containing quartz sand, next a layer of lateritic gravel, then an old volcanic soil, weathered to a latosol with many lateritic concretions, and finally on its bottom fresh basalt boulders.

The latter originate from an old lava flow which came to a standstill at the mouth of the Malele river at $140^{\prime}$. It was concluded from the sequence of deposits observed in the exposed valley wall, that the weathered top layers of the old volcanic soil developed on top of this lava flow have been completely washed away up to where the valley floor reaches the $180^{\prime}-200^{\prime}$ level (not, as might have been expected the $220^{\prime}$ marine plateau level - cf. graph 3 ) and only partly between $200^{\prime}$ and $220^{\prime}$.

This lava flow is one out of several, all of which were levelled and partly denuded of their weathered top layers, but in some cases subsequently covered with marine deposits when the sea stood at $220^{\prime}$. The strip of land between $220^{\prime}$ and $200^{\prime}$ elucidated another aspect in the present topography of this particular area. It was noted that part of this strip, i.e. where it was found to be covered with marine deposits derived from the Precambrian and containing quartz sand, followed the gentle slope from $300^{\prime}$ to $220^{\prime}$ without a break down to $200^{\prime}$, whereas another part, in which the M'Pundu river is situated, was characterized by an abrupt escarpment at the $200^{\prime}$ line some 10 to $20^{\prime}$ downwards without any coverage of quartz containing sediments. The absence of the latter is obviously due to sea currents, whose speed prevented any material from being deposited. Evidence for it was also given by the occurrence of swamps at the foot of such escarpments.

In the absence of a break in the slope at $220^{\prime}$ resulting in a smoothly sloping upper plateau running from $300^{\prime}$ down to $200^{\prime}$, it would seem as if the $200^{\prime}$ line was the beach line of the next plateau instead of the $220^{\prime}$ line found elsewhere. The true picture is however, that these lava flows, or more exactly the parts which were situated between their solidified concretional subsoil down to the unweathered lava, withstood the levelling effect of the sea to a larger extent than the volcanic deposits (mudflows) of the Tiko plain.

Their presence could also be traced back in the longitudinal profile of the M'Pundu river (graph 3), where the lava front is indicated by the sudden increase in gradient at 
$140^{\prime}$, at which level the unweathered front of the old volcanic lava flow in the Malele river was also found. The level of the surrounding land, as measured by the depth of the valley, was $200^{\prime}$, which was shown to be the level of the denuded top of the lava streams, and which, being a rather ffat surface, had the same effect on the river gradient of the M'Pundu river as discussed before in respect of marine plateaux. It was, therefore, concluded that in this particular area there were two plateaux, viz. a marine plateau between $120^{\prime}$ and $220^{\prime}$ which had been superimposed upon, and which at the same time had enabled the formation of a "lava" plateau between 140 ' and 200 '.

The pre-marine age of these lava flows was also inferred from the "marine type" of gradient of the Malele river, where it runs on their denuded tops on the $220^{\prime}$ to $300^{\prime}$ marine plateau (cf. graph 3).

It would appear therefore that the reddish weathered soils found on the $220^{\prime}-300^{\prime}$ plateau were the same as those observed in the nearby valley of the Malele river between $200^{\prime}$ and $140^{\prime}$ above M.S.L. This lava plateau extends to the areas bordering the Mungo river, i.e. the northern half of the Mungo area and the southern half of the M'Pundu area. It was shown in chapter $2 \mathrm{~B}$, that the further these flows descended, the larger the distance between the Mungo river and the $300^{\prime}$ escarpment. It was also seen, that the course of the Mungo river was diverted by this lava plateau, along whose edge it runs between $200^{\prime}$ and $140^{\prime}$ above M.S.L.

A further complication arose from the observation of very patchy growth of oil palms on the $220^{\prime}-300^{\prime}$ plateau (plate 2 - chapter 5). Patches of good growth are invariably related to pockets of much younger, black and unweathered volcanic material. The origin of the latter material could be traced back to volcanic flows of a recent, i.e. post marine, origin, which came to a standstill at about the $300^{\prime}$ line, in much the same way as was shown to have occurred in the Tiko plain in the area between the Sonne and Essoasso rivers, when the sea had regressed to the $120^{\prime}$ beach line.

The same volcanic material also blocked the upper course of the Ombele river (graph 3). Its course at the $180^{\prime}$ level is only $900^{\prime}$ away from the Malele river valley, but, being of a marine age, it runs perpendicular to the contour lines and thus also to the deep pre-marine river valley of the Malele. The Ombele river thus shows yet another variation in its longitudinal profile, viz. after it crosses the $120^{\prime}$ beach line it gradually sloped up to the $140^{\prime}$ lava terrace, and from there it slopes up steeply to the $180^{\prime}-200^{\prime}$ top of the lava plateau and without a break and even steeper up to the postmarine volcanic flow to $240^{\prime}$.

The different events could also be related to certain characteristics of the soils. For instance, the soil colour of the marine and young volcanic deposits are in the $10 \mathrm{YR}$ Munsell range, the old exposed volcanic deposits being between 2.5 and 5 YR, while different mixtures of these soils, as found between the Malele river valley and the upper course of the Ombele between $160^{\prime}$ and $180^{\prime}$, have a colour range varying between 5 to 7.5 to $10 \mathrm{YR}$. The silt to clay-ratio of the marine soils built up from Precambrian material amounts to 0.9 , but is much lower, about 0.4 , for some soils mixed with material of volcanic origin. The latter soils contain varying amounts of quartz sand, as distinct from the pure volcanic soils.

Examining the Ekona area below the $300^{\prime}$ contour line as a whole, further evidence for the detailed picture given above, was supplied by the presence of huge basalt boulders (up to 5 meters in diameter) on the $200^{\prime}$ lava terrace, by a marked concentration of rocks along the $140^{\prime}$ line and by another deeply cut in pre-marine valley near the M'Pundu oil mill, which runs almost parallel to the present contour lines, but perpendicular to the pre-marine contour lines in so far as they could be reproduced from the direction of the lava flows. 
The sequence of geological events and the resulting topographical changes in their effect on the river courses discussed so far, deals mainly with the effect of the sea on the old pre-marine topography. The length profile of the Benoe river is an example of a post-marine, i.e. post-glacial topographical change.

It is seen from graph 2 , that the Benoe river is hardly cut in, that its gradient was relatively steep and its length shorter than of any of the other rivers (cf. also graph 1). The different marine plateaux, however, are still noticeable in the form of rapids where the river crosses the $120^{\prime}$ and $220^{\prime}$ contour lines. The river bed must have been filled up by a mudflow, because a lava flow would have given the riverbed a different appearance (30). Evidence for it other than already supplied in chapter 3, was given also by the following observations:

a. contrary to other rivers, the land at the mouth of the Benoe river juts out far into the mangroves, probably owing to material that came down with sub-recent mudflows.

$b$. going from the Benoe river in a northeasterly direction towards the Ndongo river, a number of rivulets are deeply cut in up to the $120^{\prime}$ line, where they either rise or whereafter they run in a shallow valley. Going further N.E. a similar phenomenon was noticed at the $220^{\prime}$ line.

c. from a point of view of microrelief, it appears that the Benoe river runs on a "ridge" in the landscape, i.e. the mudflow in which it has cut itself in again. The lower lying land between two river ridges has apparently not been covered to the same extent with material from mudflows.

$d$. the soils on the ridges have a young undeveloped profile (see table 7 II), whereas the lower lying soils are stratified, sometimes concretional and with a fragipan occurring at a varying depth.

The stratification mentioned sub $d$ might be due to aeolian ash deposits, which during the weathering process formed a fragipan consisting of a layer of mostly coarse sandy material, probably luted by hydrolysis of easily weatherable volcanic glass, or to the action of the sea which relaid these premarine volcanic deposits. In the latter case, the fragipan was the original sea bottom, which during or after transgression of the sea was to a variable extent covered with deposits from more recent volcanic material, eventually water laid. To support this view, it was observed during the soil survey that on a rather flat marine plateau as, for instance, between the Sonne and Ndongo river between $80^{\prime}$ and $120^{\prime}$ (graph 2), the fragipans were consistently found at a depth of between 50 and $100 \mathrm{cms}$. In the lower lying more strongly sloping strip of land along the Benoe river ridge (cf. length profile Benoe river graph 2), however, the depth at which fragipans occurr, decreases with decreasing altitude until at a level of about $40^{\prime}$ above sea level they are found near the surface of the soil.

In other words, the sea bottom, alternatively the fragipans, consisting of coarse sandy volcanic material but containing a few quartz grains, was covered with young volcanic material, especially along the river (alternatively creek) courses. This explanation of the formation of fragipans would appear to be in line with the description given by NICKLÈs (cf. chapter $2 \mathrm{D}$ ) for the "carapaces". occurring in alluvial soils of Quaternary origin, and consisting of a mixture of sand and clay.

The age of the mudflows, deposited on top of the fragipans, should therefore be considered as post-marine in the sense of after the sea retreated from a higher to a lower beach line. This was shown to have occurred in the transitional zone from volcanic to non-volcanic in the eastern half of the volcanic part of the Tiko plain between the Ndongo and Essoasso river. Going in a more westerly direction the mudflows become relatively more recent because they filled the river valleys up to a lower altitude 
with as the extreme case the Benoe mudflow, which was shown to have been deposited after the sea regressed down to the $20^{\prime}$ level approximately.

In line with this is the observation of the more frequent occurrence of rocky fronts of mudflows, when going in a westerly direction. The slopbasins that go with the fronts of mudflows, often form swamps, for instance in the Ekona area (cf. chapter 3) and particularly when there is a distinct boundary between volcanic flows and older formations. In the Tiko plain the slop-basins did not form swamps, but are characterized by clear-cut patches full of lateritic concretions, which must have been grubbed up from the volcanic subsoil of pre-marine origin. The age of the subsoil is comparable with the pre-marine volcanic deposits encountered in the Malele river valley and the neighbouring $220^{\prime}-300^{\prime}$ terrace. These lateritic concretions should, therefore, a priori not be considered as the result of post-marine hydrographic conditions or weathering processes. In this context the time has been too short to form lateritic concretions.

\section{Outcrops}

The successive marine plateaux distinguished in the previous paragraph, were shown to have formed beach lines.

If these shores were in contact with rocky soils, the surf should have rounded off the boulders. They were indeed encountered at either of the marine plateau levels. It is obvious that outcrops of pre-marine age in a marine plateau are the indicated sites to look for them. These outcrops, often remnants of pre-marine craters (cf. the preQuaternary basalt irruptions of chapter 2), and very conspicuous in an otherwise levelled landscape, supplied additional evidence for the existence of marine plateaux. In the surveyed parts of the Tiko and Ekona areas, their height corresponds with that of the different beach lines. Usually, they are $300^{\prime}$ high in the $220^{\prime}-300^{\prime}$ plateau, $220^{\prime}$ in the $120^{\prime}-220^{\prime}$ plateau and $120^{\prime}$ in the lowest plateau.

If a $300^{\prime}$ outcrop is situated in a $120^{\prime}-220^{\prime}$ terrace, two beach lines at $300^{\prime}$ and $220^{\prime}$ respectively should have been formed. This was indeed observed and was another indication that the sequence of high sea levels was first at $300^{\prime}$, then at $220^{\prime}$ and finally at $120^{\prime}$.

There are numerous examples of such outcrops, one of which is Big M'Pundu Hill. It is $300^{\prime}$ high, is situated in the $120^{\prime}-220^{\prime}$ terrace, has on its slopes the rounded basalt boulders characteristic for a sea shore, and is covered with more or less thin layers of marine deposits, containing quartz sand, on top of the weathered, lateritic concretions containing, red clay of old volcanic, i.e. pre-marine, origin. Marine deposits of nonvolcanic origin were not laid on the top, which was levelled off to $300^{\prime}$ at the time the sea stood at the $300^{\prime}$ level.

Very often swamps are situated at the foot of such usually steep outcrops. They must have been formed during the marine period when the present outcrops were islands in a sea around (part of) which sea currents had worn channels or, in existing creek or alternatively river valleys, pools in much the same way as the slop-basins at the foot of the front of mudflows.

In the next chapter it will be shown that crops grown on such localised outcrops present problems distinct from those of the surrounding land with different soils (cf. oil palms - Vascular Wilt disease).

\section{Extrapolation of the results to non-surveyed areas}

An attempt was made to extrapolate the knowledge acquired in the areas already surveyed in detail to non-surveyed regions below $300^{\prime}$ elsewhere. 
a. The Mabeta area. This very broken area, bordering the Tiko plain in the southwest, is of old volcanic origin. The Ombe river is the border line between the two areas and shows in its longitudinal profile the characteristics discussed in the foregoing pages. The succession of high ridges (up to $1000^{\prime}$ ) and deep valleys, which clearly indicates the levelling effect of the sea up to $300^{\prime}$, was discussed before and was compared with the formation of a relic ria type of landscape. Furthermore, there are a number of outcrops of either $120^{\prime}, 220^{\prime}$ or $300^{\prime}$ high.

b. The Victoria-Bota area. In this region of young volcanic origin on the southern spurs of the Cameroon Mountain, there are a number of outcrops with altitudes, which correspond with those of the beach lines of the marine plateaux.

A perfect example is the extinct volcano of pre-marine origin in the Botanical Garden at Victoria. Its top is $300^{\prime}$, while its eastern slope at $220^{\prime}$ is interrupted by a plateau, in which perfectly rounded off boulders covered with reddish weathered material of old volcanic origin were found. The extinct crater of old volcanic origin at Bota-Kie is another example and will be discussed in the next chapter in relation to the occurrence of Vascular Wilt disease in oil palms.

c. The Bibundi-Idenau area. The Bibundi lava flow of 1922 on the S.W. slope of the Cameroon Mountain is well known from literature (35). The topographical maps clearly show that the topography of the landscape was reversed in the area covered by the lava flow.

This region can be compared with the Tiko plain, as it was clearly divided into two parts of different volcanic age by the river Messingili (cf. the Sonne river in the Tiko plain or rather the Ombe river between the Tiko plain and the old volcanic Mabeta area).

Here again outcrops have the same altitude as those of the known marine plateaux.

Going north from the Bibundi lava flow there are consecutively the Bibundi, Nimonne, Becongolle, Sanje and Messingili rivers, whose courses are older in this order, owing to less interference from more recent volcanic deposits. The Bibundi river profile can be compared with that of the Benoe river except that the former river was not filled up with a mudflow but with a lava flow. As a result of it there is a steep escarpment at the $20^{\prime}$ level as distinct from the smoother gradient of the mudflow filled Benoe river. For the rest all the peculiarities of the river profiles in the Tiko and Ekona areas are also evident in the profiles of the Idenau rivers, including the different marine plateaux.

d. The Meme river area (situated on the western slope of the Cameroon Mountain). The presence of different marine plateaux could be inferred from the altitudes of the outcrops, i.e. $120^{\prime}, 220^{\prime}$ and $300^{\prime}$ respectively.

\section{SoIl SUITABILITY AND OTHER APPLications}

The suitability of the marine deposited soils for growing crops, in particular perennial crops, under the mitigating climatical conditions is almost entirely dependent on their depth (see chapter 5).

A deep marine soil has excellent profile characteristics (table 7 I). Its nutrient supplying capacity was found to be dependent on the origin of the material. If it originated from Precambrian parent material or from old volcanic deposits of Tertiary age, the soils are poor to very poor. The soils consisting of volcanic material of a more recent age, for instance of just before, during or after the glaciation era, were potentially very rich and suitable for the cultivation of an exigent crop like bananas. 
The soil suitability decreases rapidly with the appearance of relic concretional layers and lateritic hardpans of older formation in the rooting medium, i.e. with decreasing depth of the marine deposits. Such a root impeding horizon in an A-D profile was considered to make these soils unsuitable for growing perennial crops on a plantation scale, when they appear within $40 \mathrm{cms}$ from the top.

The results of this study might also be used in planning sites for bridging rivers. With regard to the Tiko plain for instance, but also at Idenau, the knowledge of the existence of marine plateaux involves that a river recently filled up with a volcanic flow can be bridged almost anywhere between $20^{\prime}$ and $300^{\prime}$, but, if not recently covered by volcanic flows, rather at or above the $120^{\prime}$ (or 220') line than below it. For, below these levels the river valleys are wider and/or more deeply cut in, the surrounding land often being swampy.

Another application might be for purposes of irrigation. The site for an irrigation weir should be chosen at the lower end of a marine plateau and preferably in a recently filled up, hence not deeply cut in river, as is the case with the Benoe (and Bibundi) river.

The knowledge of the occurrence of water impermeable subsoil layers, such as hardpans or perhaps in some cases fragipans, might also be useful in planning the layout of irrigation channels.

Another application is that of the selection of a site for a hydroelectric power station. In this respect, it is of interest to note that the power station at Malele is situated at the mouth of the Malele river, i.e. at the end of the lava plateau at $140^{\prime}$ above M.S.L.

\section{Conclusions}

Photoanalytical interpretation of aerial photographs reduced the field work considerably in a soil survey carried out in land lying below 300 feet above M.S.L. at Tiko and Ekona in the Southern Cameroons.

Soil maps of a scale 1 : 5000 could be produced using a field grid of only one boring per hectare.

The profile and physiographic characteristics of the soils and the land respectively, situated on the lower slopes of the Cameroon Mountain below the $300^{\prime}$ contour line, strongly suggests a common causal agent in their formation and deposition.

The results of a detailed study, in particular of the length and depth of the river profiles, warrant the hypothesis that these soils were deposited by the sea in a rather recent geological history.

The discovery of different beach lines at successively $300^{\prime}, 220^{\prime}, 120^{\prime}$ and probably $20^{\prime}$ pointed to the glaciation period as the era of their formation and at the same time a gradual rise of the land, also because it would be unreasonable to assume that the sea in the Pleistocene era reached a level which was $300^{\prime}$ higher than the present one. The land must have been raised uniformly in view of the evidence that the different beach lines reached the same level over a wide area, i.e. all around the Cameroon Mountain.

As a result of these high sea levels landscapes resembling rias were formed, the relics of which were discussed in detail.

The possibility to trace back the mode of deposit and the (relative) age of volcanic flows, provided a very useful approach to a comprehensive survey of the soils on the slopes of the Cameroon Mountain above the $300^{\prime}$ contour line.

Other applications of the present study, for instance in relation to agricultural practices and civil engineering, were briefly indicated. 


\section{ChAPTER 5}

\section{THE SUITABILITY OF THE SOILS OF THE LOWER EASTERN SLOPES OF THE CAMEROON MOUNTAIN FOR VARIOUS PERENNIAL CROPS}

\section{A. INTRODUCTION}

The suitability of a soil for growing crops is defined by soil-crop relationships, climatical conditions, and economic factors.

The economic factors will not be discussed here. Furthermore, the suitability of the soils under consideration will only be related to the main crops grown by the Cameroons Development Corporation. They are Gros Michel bananas, oil palms, rubber, cacao and tea, i.e. perennial crops grown as monocultures on a plantation basis, hence on a large scale.

The study of the relationship between these crops and the soils under consideration is probably best compared with the methods applied in studying soil - crop relationships in European horticulture. There are, however, distinct differences, the most important one being that growth and yield of these crops of the humid tropics are not confined to a specific part of the year. It implies that the relationship between soil suitability and the quantity and quality of the crop yield produced in any one year is not so obvious as in temperate zones. This is particularly true in respect of the monocotelydonous crops such as bananas and oil palms. Their produce is derived from generative organisms of the plant, the number of fruits to be harvested (quantity) being largely determined during a different period, i.e. prior to the emergence of the inflorescence, than that of the weight of the fruits (quality). Fruit weight is - to a large extent - dependent upon the conditions prevailing during the period from emergence of the inflorescence till harvesting.

In bananas, where each plant produces one bunch, the size of the bunch depends upon the number of hands it carries (generally varying between 6 and 12 hands per bunch). The number of hands on a bunch is determined 6 to 9 months before the inflorescence emerges. The size, i.e. length, of the individual fruits (so called: fingers) on each hand is, however, to a much larger extent dependent upon the conditions prevailing during the period from "shooting" (i.e. emergence of the inflorescence) till harvesting (varying between 2 and 4 months).

In oil palms normally one inflorescence develops in each leaf axil. The number of bunches to be produced depends on the number of female inflorescences produced. The higher the ratio female to male inflorescences, often expressed as the sex ratio, i.e. the ratio female to total inflorescences, the larger the yield. The sex ratio is determined some 2 years before the actual date of harvest of the fruit $(7,8)$. The size of the bunch and other bunch characteristics, for instance percentage oil in pericarp, are to a larger extent determined during the period from emergence of the inflorescence to harvesting.

From this it is obvious that the assessment of the suitability of a soil by means of its potential yielding capacity for crops like bananas and oil palms has to take into account these cropping characteristics.

Of the five crops under consideration, cacao fits best to a comparison with orchard crops of the temperate zone. It flowers prolificly, the numbers of fruit set and reaching maturity being largely dependent upon the ecological conditions during flowering and ripening respectively.

The produce of tea and rubber is derived from vegetative substances of the plant, as distinct from bananas, oil palms and cacao. In this respect soil-crop relationships in tea and rubber might be compared with those in forestry. 


\section{B. Chemical FERTILITY OF THE SOILS}

The three main groups of soils distinguished previously, i.e. the young and old volcanic soils and the marine alluvial soils, vary greatly in their chemical fertility.

The young volcanic soils are abundantly supplied with slightly weathered basalts, consisting of plagioclases and volcanic glass as the lighter and olivine and augite as the darker minerals. The weathered and leached soils of old volcanic origin do not contain such mineral resources, except for some usually large basalt boulders of Tertiary age ("la série noire inférieure"). It was shown that the parent material of the marine alluvial soils originated predominantly from cristalline rocks of Precambrian age. The latter soils were found to be poorly supplied with nutrients $(25,24)$, although admixture to a greater or lesser extent with volcanic ash material had a rejuvenating effect (cf. western part of the Tiko plain).

The fertilizing value of volcanic ash was computed by MoHr and VAN BAREN (35). These authors found that the material blown out in one night by one single eruption of the Kelut Mountain in Indonesia contained $1.6 \mathrm{~kg} \mathrm{P}_{2} \mathrm{O}_{5}, 0.8 \mathrm{~kg} \mathrm{~K}_{2} \mathrm{O}, 28.8 \mathrm{~kg} \mathrm{CaO}$ and $0.6 \mathrm{~kg} \mathrm{MgO}$ per hectare for an ash layer of a mean thickness of $1 \mathrm{~mm}$. Furthermore, they drew attention to the low potash content of volcanic ash, which was in line with the large responses obtained from potash fertilizing in numerous field trials in bananas (26), oil palms (24), rubber (25) and tea (27) in the Cameroons, and those obtained with pasture crops on young volcanic ash soils in Japan (32). The latter soils, although rich in bases and still at initial stage of weathering, had not enough ability to release $K$ from non-exchangeable into exchangeable form for pasture crops to grow normally.

TABLE 9. Chemical analysis of basalts (Cameroon Mountain) and granite (Kupe Mountain, Tombel)*

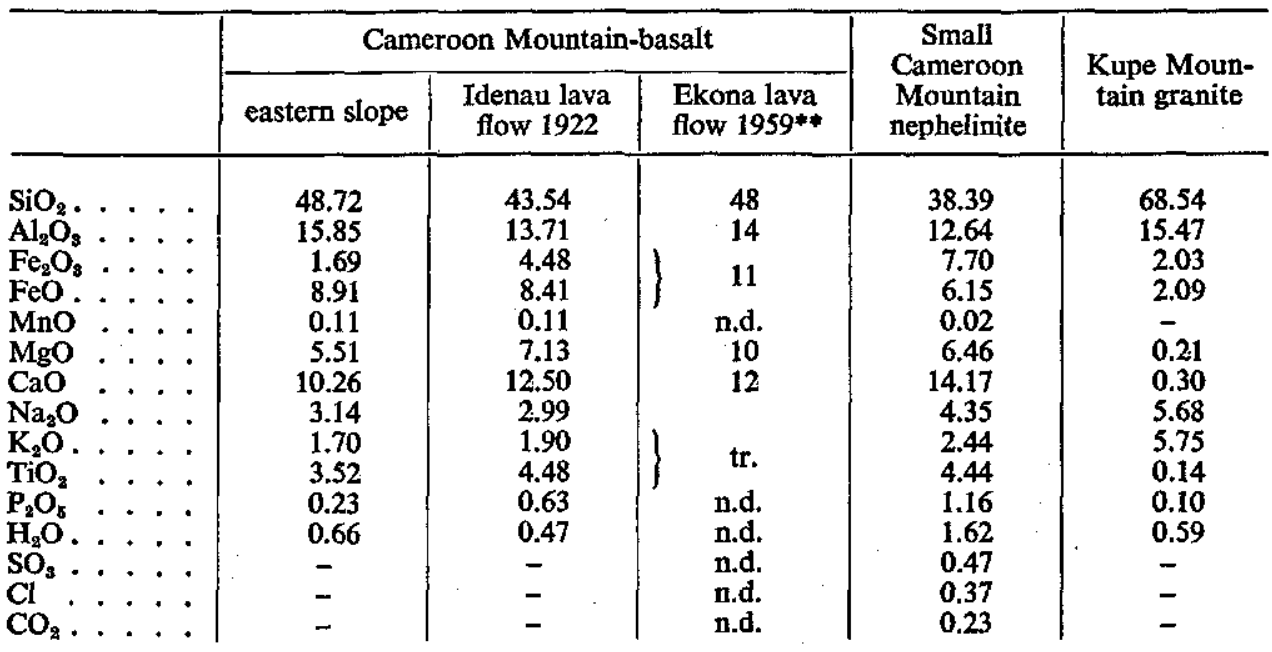

* Cf. KRENKeL (33). ** Analysis by Shell Company - Nigeria.

It will be seen from table 9 that basic volcanic material is relative to its $\mathrm{CaO}$ and $\mathrm{MgO}$ contents very poor in K-bearing minerals, whereas the granitic parent material of the marine alluvial soils is relatively rich in potash.

The low K-contents of volcanic parent material will appear to be an important factor in the potential yield capacity, hence the suitability of the volcanic soils, particularly in respect of crops with large K-requirements like bananas and oil palms. 
Analysis of samples taken from soils derived from these two different parent materials are shown in table 10 . The samples were numbered in such a way that the lower numbers represented the younger soils.

TABLE 10. Chemical composition of marine alluvial and volcanic soils.**

\begin{tabular}{|c|c|c|c|c|c|c|c|c|}
\hline & \multicolumn{5}{|c|}{ Young volcanic soils } & \multicolumn{3}{|c|}{ Marine alluvial soils } \\
\hline & \multirow{2}{*}{$\begin{array}{c}\begin{array}{c}\text { Mount } \\
\text { Kupe }\end{array} \\
1^{* * *}\end{array}$} & \multicolumn{4}{|c|}{ Cameroon Mountain Tole - estate } & \multirow{2}{*}{$\begin{array}{c}6 \mathrm{a} \\
\left(\text { at } 4^{\prime \prime}\right)\end{array}$} & \multirow{2}{*}{$\begin{array}{c}6 b \\
\text { (at } 36^{\prime \prime} \text { ) }\end{array}$} & \multirow[t]{2}{*}{7} \\
\hline & & 2 & 3 & 4 & 5 & & & \\
\hline Exchange capacity* & 103.6 & 92.6 & 82.1 & 98.0 & 45.5 & 34.1 & 25.2 & 14.5 \\
\hline Ca-exchangeable* & 37.2 & 25.8 & 15.8 & 14.1 & 7.0 & 2.1 & 0.4 & 0.8 \\
\hline K-exchangeable* & 3.6 & 5.0 & 6.7 & 5.5 & 2.0 & 0.3 & 0.1 & 0.5 \\
\hline Na-exchangeable* & 1.5 & 0.7 & 0.6 & 1.3 & 0.3 & - & - & - \\
\hline Mg-exchangeable* & 13.3 & 6.8 & 7.1 & 7.1 & 2.6 & 0.9 & 0.5 & 0.8 \\
\hline $\mathrm{K} / \mathrm{Ca}$ & 0.09 & 0.19 & 0.42 & 0.39 & 0.29 & 0.14 & 0.33 & 0.64 \\
\hline $\mathrm{K} / \mathrm{Ca}+\mathbf{M g}$ & 0.07 & 0.15 & 0.29 & 0.26 & 0.21 & 0.10 & 0.16 & 0.32 \\
\hline $\mathrm{Ca} / \mathrm{Mg}$ & 2.8 & 3.8 & 2.2 & 2.0 & 2.7 & 2.3 & 0.8 & 1.0 \\
\hline$\%$ clay & 98 & 29.8 & 33.6 & 32.0 & 48.3 & 100 & 100 & 100 \\
\hline P total p.p.m. & 4208 & - & - & - & - & 2012 & 2176 & 750 \\
\hline Base saturation & 55.6 & 41.4 & 36.6 & 29.5 & 26.5 & 10.5 & 4.0 & 14.4 \\
\hline $\mathrm{pH}-\mathrm{H}_{2} \mathrm{O}$ & 6.5 & 5.6 & 5.4 & 5.2 & 5.1 & 4.9 & 5.7 & 4.7 \\
\hline$\hat{\mathrm{pH}}-\mathrm{KCl}$ & - & 4.9 & 4.8 & 4.7 & 4.6 & - & - & - \\
\hline
\end{tabular}

* m.e. 100 g clay.

** Analysis by Dept. of Agric. Research, Ibadan, Nigeria.

*** See text.

It will be seen from table 10 that the younger the soil, generally the higher the exchange capacity per $100 \mathrm{~g}$ clay, $\mathrm{pH}$ and base saturation, exchangeable $\mathrm{Ca}$ and $\mathrm{Mg}$ contents, but the lower the $\mathrm{K} / \mathrm{Ca}+\mathrm{Mg}$ and $\mathrm{K} / \mathrm{Ca}$ ratios. The samples taken at Tole, a tea estate of approximately 700 acres, show increasing clay contents with increasing age. This characteristic can often be usefully applied as a means of dating the relative age of volcanic deposits, particularly when originating from the deposits of one or a related group of eruption points (16).

These data substantiated the relationships between exchange capacity and distribution of ions with different valences as described by SCHUFFELEN and MIDDELBURG (45) in evidence of the presence of the Donnan equilibrium of soil colloidal behaviour.

Comparing marine alluvial with young volcanic soils, the valence effect, i.e. the relative distribution of mono- and divalent ions was demonstrated by the lower $\mathrm{K} / \mathrm{Ca}$ and $\mathrm{K} / \mathrm{Ca}+\mathrm{Mg}$ ratios of the soil with the larger exchange capacity, viz. the volcanic soils, while within the latter group the same trend was noticeable depending on the state of eluviation of the soil and in respect of the Tole samples, its degree of weathering. The more weathered the soil, the lower its base saturation and $\mathrm{pH}$, and the higher the $\mathrm{K} / \mathrm{Ca}$-ratio. The effect of activity coefficients on cation ratios was apparent in the lower $\mathrm{Ca} / \mathrm{Mg}$ ratios of the marine alluvial soils and of the more developed and leached samples of the volcanic soils.

Detailed examination of the individual samples showed that samples Nos. 3, 4 and 6 (taken at $4^{\prime \prime}$ depth) were not exactly in line with the observed age trend within the volcanic and marine alluvial group of soils respectively.

With regard to the volcanic samples, it might be explained along the following lines: available descriptions of the eruptive pattern of the Cameroon mountain and close 
observation of the 1959 eruption (30) showed that long after the actual production of lava had ceased, the craters remained in the solfatara stage, emitting sulphuric gases. The Idenau eruption of 1922, for instance, lasted for approximately 6 months, whereas the orifice remained in a decadent stage for another two years. The active part of the 1959 eruption lasted for approximately 6 weeks, whereas the solfatara stage was still going on two years later. The acidifying effect of these gases when precipitated with the rain, might well explain the unexpectedly high $\mathrm{K} / \mathrm{Ca}$-ratios of samples 3 and 4, and in general the high acidity of the deposits around the Cameroon mountain (pH 5.1-5.6). This as distinct from these of mount Kupe at Tombel (pH 6.5). The presence of so called sulphur wells on the mount Cameroon and their absence on the Kupe mountain provided further evidence for it.

It was also in line with the analytical data obtained by Prillwitz, as quoted by SCHUFFELEN and MIDDELBURG (45), who established a correlation between the increase in the ratio monovalent to divalent ions and the base saturation, after acidifying Java soils artificially by means of increasing quantities of sulphur.

The "abnormal" trend of the " $a$ " sample in profile 6 in the marine alluvial soil range was considered to be the result of admixture of volcanic ash from a nearby crater. The analysis of a lower horizon (36") of the same profile showing more truly the characteristics of a marine type of soil, would seem to be in agreement with it.

Finally it would appear from the high exchange capacities of the young volcanic soils that the first stage in the laterisation process of fresh volcanic material passes through the phase of the montmorillonitic clay mineral, as already suggested by MOHR and VAN BAREN $(35$, p. 181). Of the two conditions, mentioned by the latter authors, which favoured the weathering of effusiva of recently active volcanoes to montmorillonite bearing clays, the pronounced dry season certainly played its part. The second condition mentioned, that is of sufficient leaching and eluviation of both silica and bases being prevented by layers of very fine ash, was not apparent in the freely draining soils of the Cameroons, although the formation of fragipans and stoney pan layers impeding free drainage, was noticed in localised areas of even topography.

\section{SOIL-CROP RELATIONSHIPS IN BANANAS}

The main banana plantations of the Cameroons Development Corporation on the eastern slope of the Cameroon Mountain are or were situated in the Ekona and Tiko areas on young volcanic and marine alluvial soils respectively.

Simmonds (47) stated in his book on Bananas that bananas are cultivated successfully on soils of very various origin, physical structure and composition. Furthermore. that the only feature the banana soils have in common is good drainage.

The difference in origin (table 9) and fertility (table 10) of the two groups of soils a1 Ekona and Tiko enabled a comparison to be made between the suitability of these twc soils for growing bananas.

\section{Marine alluvial soils}

Banana fertilizer experiment No. I was one of the several fertilizer and husbandry trials laid down in the Tiko plain. It was situated on level land (Ms-series) about 1000' east of the Essoasso river at $30^{\prime}$ above M.S.L. in the Pungo section. It covered an area of approximately 5 acres, was laid out in an existing banana plantation and received its first fertilizer applications at the end of 1952. The layout of the three replications of the trial (each covering an area of 0.96 acres exclusive the area occupied by bufferrows) was done in such a way that each of them covered a different type of the marine alluvial sandy clays (Ms-series) characteristic for this part of the Tiko plain. 
The soil in replication $\mathrm{A}$ of the trial consisted of a dark greyish brown (Munsell colour 10 YR 4-2) loam to loamy clay in the top $20 \mathrm{~cm}$, changing into a yellowish brown (Munsell colour 10 YR 5-4) sandy clay to clay from $25 \mathrm{~cm}$ down to $120 \mathrm{~cm}$. Few faint reddish brown mottles appeared at a depth of $80 \mathrm{~cm}$. The soil in replication $C$ consisted of a yellowish brown (10 YR 5-4) loamy clay in the top $20 \mathrm{~cm}$, a yellowish brown sandy clay to clay from $20 \mathrm{~cm}$ down to $110 \mathrm{~cm}$ with few black Mn-concretions occurring between 30 and $40 \mathrm{~cm}$ and few fine lateritic concretions and reddish brown mottles as from $40 \mathrm{~cm}$ downwards. At $40 \mathrm{~cm}$ depth there was a slightly indurated layer. At $100 \mathrm{~cm}$ the lateritic concretions increased in numbers, forming a hard layer of lateritic gravel. The soil in replication $B$ was transitional between replication $\mathrm{A}$ and $\mathrm{C}$, consisting of a dark brown (10 YR 4-3) loam to loamy clay in the top $20 \mathrm{~cm}$, a loamy clay between 20 and $40 \mathrm{~cm}$ with a few black Mn concretions, and a dark yellowish brown (10 YR 4-4) sandy clay down to $120 \mathrm{~cm}$, containing an increasing number of Mn concretions. Few medium reddish brown mottles appeared at a depth of $100 \mathrm{~cm}$. The $\mathrm{pH}$ of this area was $5.3(\mathrm{pH}-\mathrm{KCl} 4.15)$. The yields in these three replications were recorded during the period 1953-1957 (table 11).

TABLE 11. Banana yields in period 1953-1956 inclusive.

Area: Pungo - Tiko experiment No. I

Soil: Marine alluvium (Ms - series).

\begin{tabular}{c|r|r|r|r|r|r}
\hline \multirow{2}{*}{ Replications } & \multicolumn{2}{|c|}{ Bunches* $^{*}$} & \multicolumn{2}{c|}{ Total weight } & \multicolumn{2}{c}{ Mean bunchweight } \\
\cline { 2 - 7 } & No. & $\%$ & $\mathrm{~kg}$ & $\%$ & $\mathrm{~kg}$ & $\%$ \\
\hline Year 1953 & & & & & & \\
A & 530 & 100 & 7240 & 100 & 13.7 & 100 \\
B & 506 & 95 & 6729 & 93 & 13.3 & 97 \\
C & 491 & 93 & 5529 & 76 & 11.3 & 82 \\
Year 1954 & & & & & & \\
A & 422 & 100 & 7010 & 100 & 16.6 & 100 \\
B & 356 & 84 & 5936 & 85 & 16.7 & 100 \\
C & 272 & 64 & 4210 & 60 & 15.5 & 93 \\
Year 1955 & & & & & & \\
A & 391 & 100 & 5938 & 100 & 15.2 & 100 \\
B & 331 & 85 & 5216 & 88 & 15.8 & 104 \\
Year 1956 & 292 & 75 & 4113 & 69 & 14.1 & 93 \\
A & & & & & & \\
B & 303 & 100 & 4133 & 100 & 13.6 & 100 \\
C & 227 & 75 & 3022 & 73 & 13.3 & 98 \\
& 185 & 61 & 2229 & 54 & 12.0 & 88
\end{tabular}

* Bunches harvested at full grade.

It will be seen from table 11 that the yields in the three replications differed significantly, although their profile characteristics and the drainage conditions of the three soils types were not very distinctly different, certainly not in the top $40 \mathrm{~cm}$. The yield differences between the replications became progressively more marked with time, so that in $\mathbf{1 9 5 6}$ the yield of replication $\mathrm{C}$ was only half of that of replication $\mathrm{A}$. These observations bear out the statement by SimmonDs (47), quoted previously, that good drainage is of crucial importance for a banana soil.

At a planting density of 12 ' square, allowing two plants to grow per point, the num- 
ber of plants in this trial amounted to 604 per acre. The highest production obtained per replication of 0.96 acre was 530 bunches, or the equivalent of 550 bunches per acre, namely in replication $A$ in 1953. The fact that the maximum production of 604 bunches per acre was not obtained was due to losses from various causes, foremost amongst which were the losses due to wind damage. The progressively decreasing number of bunches harvested in successive years was mainly due to losses from Panama Disease, which is caused by a soil-inhabiting fungus. The first cases of Panama Disease were observed towards the end of 1953. From then on the disease spread gradually throughout the whole experimental area. The production figures of table 11 suggested that the disease spread more rapidly in replications $C$ and $B$ than in $A$.

A possible relationship between the incidence and spread of Panama Disease and the profile characteristics of a soil was investigated in another fertilizer trial i.e. Pungo No. VIII, also situated in the Pungo section. It was known that in the latter trial the layers of lateritic gravel, as encountered at a depth of $100 \mathrm{~cm}$ in replication $\mathrm{C}$ in Pungo trial No. I, came nearer to the surface. Experiment VIII was situated one mile northeast of the Essoasso river at $80^{\prime}$ above M.S.L.. The soils were the same as those described for experiment No. I, the main difference being the depth of occurrence of the layers of lateritic gravel.

The first cases of Panama Disease were recorded in the third quarter of 1955 and appeared to be uniformly spread over the experimental area of approximately 5 acres. In the beginning of 1957 a grid of 34 points was superimposed on the experiment and at each point a profile pit was dug. The profiles of these pits were examined and the following characteristics described: depth, horizon boundaries, colour, texture, coarse fragments, structure, consistence, $\mathrm{pH}$ and mottling. A close study of these descriptions revealed that the principal difference between the profiles consisted of the thickness and hardness of gravelly layers in conjunction with their position (depth) in the profile. The profiles were scored using a system based upon these characteristics in the following way:

\begin{tabular}{c|c|c}
\hline $\begin{array}{c}\text { position in profile } \\
\text { in cm }\end{array}$ & $\begin{array}{c}\text { slightly hard } \\
\text { gravelly layer }\end{array}$ & $\begin{array}{c}\text { hard gravelly } \\
\text { layex }\end{array}$ \\
\hline $0-10$ & 5 & 10 \\
$10-20$ & 3 & 7 \\
$20-30$ & 1 & 5 \\
$30-40$ & 0 & 3 \\
$40-60$ & 0 & 1
\end{tabular}

Hence a profile with a slightly hard gravelly layer at a depth of between 10 and 20 $\mathrm{cm}$ and with a hard gravelly layer between 30 and $60 \mathrm{~cm}$ was scored as follows:

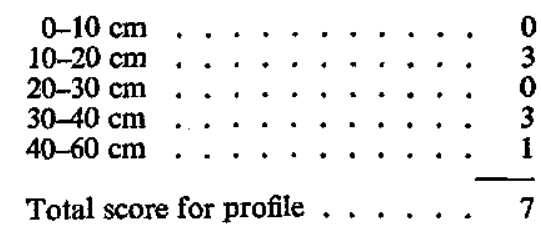

In this way all the profiles were scored and the results related to the number of cases of Panama Disease present in the 30 mats, consisting of 2 plants each, surrounding each pit. The relationship appeared to be highly significant $(\mathrm{P} 0.001)$ with a correlation coefficient of $r=+0.786$ (graph No. 4). 


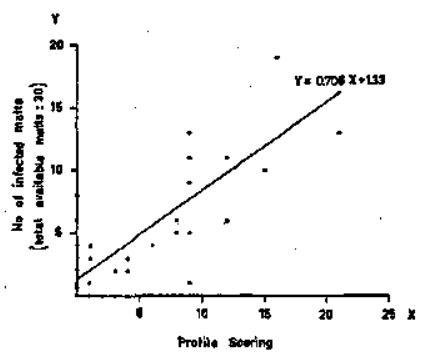

GRAPH 4

Relation profile scoring and $\mathrm{Pa}$ nama Disease
Taking into consideration that Panama Disease infection is not governed by one factor only, the obtained high correlation coefficient indicated that at least in the initial stages of incidence and spread of the disease profile characteristics played a predominant part. Approximately two years after the first cases of disease occurred, losses amounted to $8 \%$ on the good profiles (scoring 0 ), $25 \%$ on profiles with a score of 10 and $50 \%$ at a scoring of 20 .

As all the profiles were well drained, the adverse effect of the gravelly layers must have been caused by the restriction in rooting volume. In the light of these observations the statement by SimMONDS (47) would

have been better phrased as follows: unrestricted root growth, good drainage in particular, is of crucial importance in the assessment of the suitability of a soil for growing bananas.

These results also suggested that Panama Disease in its initial stages of incidence and spread is indicative of the suitability of a soil for growing bananas. It could be argued, however, that the rate of incidence of Panama Disease as an indicator of soil suitability refers to Gros Michel bananas only, other commercial clones being more resistant to the disease.

SIMMONDS (47) distinguished the following eight factors affecting the occurrence and course of the disease:" 1 . the clone grown; 2 . the age of the plant, the roots of old Gros Michel plants being more resistant to infection than those of young plants; 3 . the weather, through its influence on the course of attack, drought depressing the disease, heavy rains increasing the number of new cases recorded in a field; 4 . the general condition of the root system, strong development of new roots encouraging the pathogen; 5. the amount of inocculum available in the soil for infection; 6 . the physical state of the soil, heavy soils, other things being equal, favouring the host, light soils the pathogen; it is probable that the high and relatively constant moisture contents of heavy soils as against the low and fluctuating content of light soils is responsible for this; 7. bad drainage encourages the disease: since the pathogen is strongly aerobic, it is likely that this factor operates by rendering the host-root system more susceptible to invasion rather than by favouring the fungus; 8 . the nutrient status of the soil, highly fertile land favouring the survival of the host".

The first five of these eight factors might be considered as to be beyond control, if the susceptible Gros Michel variety is grown. Under a given set of conditions, for instance the Gros Michel banana plantations of the Cameroons Development Corporation on the eastern slopes of the Cameroon Mountain, the only means to delay the time of occurrence and the initial rate of spread of the disease is provided by the soil factors mentioned sub 6,7 and 8 . Previously the factor mentioned sub 7 was given a wider implication by relating it to rooting volume rather than to bad drainage alone. The explanation given by SIMMONDs for the differential effect of heavy and light soils on host and pathogen respectively (sub 6) would seem to be too simplified in the light of the factors mentioned sub 3 and sub 7 and the universally recognised effect of soil texture on the incidence of the disease. The latter recognition would hardly justify an explanation, which is based upon such a finely drawn balance between the water and air relationships of a soil in its differential effect on host and pathogen.

It will appear to be more obvious to approach the relationship of soil texture and disease incidence by relating it to the difference in nutrient status and nutrient availability. 
Evidence for it was supplied by the results of several fertilizer trials. Each of the three replications of experiment No. I at Pungo was subdivided into 8 plots, consisting of the following fertilizer treatments: $\mathrm{O}$ (control - no fertilizer), $\mathrm{N}$ (nitrogen at the rate of $400 \mathrm{lbs}$ sulphate of ammonia per annum per acre), $P$ (phosphorus at the rate of 400 lbs rockphosphate $30 \%$ ), K (potassium at the rate of $440 \mathrm{lbs}$ muriate of potash $50 \%$ ) and their combinations NP, NK, PK and NPK. Exactly the same design and treatments were adopted in an experiment No. MI, but with 98 instead of 72 plants per plot, at Muyuka, just north of Meanja, also on marine alluvium (Ms-series). It was laid out in an existing banana plantation (planted in 1951) and it received its first fertilizer dressings at the end of 1953. The first cases of Panama Disease were recorded in 1954.

TABLE 12. Incidence and spread of Panama Disease in experiments PI and MI situated on marine alluvial soils (Ms - series).

\begin{tabular}{c|c|c|c|c}
\hline \multirow{2}{*}{ Treatments } & \multicolumn{2}{|c|}{ trial PI infected plants } & \multicolumn{2}{c}{ trial MI infected plants } \\
\cline { 2 - 5 } & \% per 1.1.1954 & $\chi^{2}$ & $\%$ per 1.1.1956 & $\chi^{2}$ \\
\hline & 2.7 & 0.05 & 0.7 & 5.12 \\
N & 6.9 & 16.84 & 2.0 & 0.76 \\
P & 0.5 & 3.78 & 1.0 & 3.67 \\
K & 0.0 & 5.64 & 4.8 & 3.67 \\
NP & 0.0 & 5.64 & 3.1 & 0.00 \\
NK & 6.5 & 13.48 & 7.5 & 22.08 \\
PK & 0.5 & 3.78 & 2.0 & 0.76 \\
NPK & 3.3 & 4.10 & 2.0 & 0.76 \\
Mean for trial & 2.6 & & 2.9 & \\
\end{tabular}

\begin{tabular}{c|c|c|c|c}
\hline Treatments & \% per 1.1.1955 & $\chi^{2}$ & $\%$ per 1.1.1957 & $\chi^{2}$ \\
\hline O & 6.5 & 2.28 & 0.7 & 13.61 \\
N & 15.7 & 9.82 & 2.0 & 7.18 \\
P & 4.6 & 5.94 & 1.4 & 10.13 \\
K & 6.5 & 2.28 & 8.5 & 4.50 \\
NP & 4.6 & 5.94 & 6.5 & 0.37 \\
NK & 25.0 & 60.48 & 15.3 & 51.49 \\
PK & 5.6 & 3.89 & 5.4 & 0.02 \\
NPK & 7.4 & 1.09 & 5.4 & 0.02 \\
Mean for trial & 9.5 & & 5.7 &
\end{tabular}

\begin{tabular}{|c|c|c|c|c|}
\hline \multirow{2}{*}{ Treatments } & \multicolumn{2}{|c|}{$\begin{array}{c}\text { total infection } \\
\text { PI (1954) + MI (1956) }\end{array}$} & \multicolumn{2}{|c|}{$\begin{array}{c}\text { total infection } \\
\text { PI (1955) + MI (1957) }\end{array}$} \\
\hline & $\%$ & $\chi^{2}$ & $\%$ & $\chi^{2}$ \\
\hline $\begin{array}{l}\mathbf{O} \\
\mathbf{N} \\
\mathbf{P} \\
\mathbf{K} \\
\mathbf{N P} \\
\mathbf{N K} \\
\mathbf{P K} \\
\mathbf{N P K} \\
\text { Mean for } 2 \text { trials }\end{array}$ & $\begin{array}{l}1.6 \\
4.1 \\
0.8 \\
2.7 \\
1.8 \\
7.1 \\
1.4 \\
2.5 \\
2.8\end{array}$ & $\begin{array}{r}2.64 \\
0.60 \\
7.34 \\
0.00 \\
1.84 \\
35.55 \\
3.60 \\
0.07\end{array}$ & $\begin{array}{r}3.1 \\
7.8 \\
2.7 \\
7.6 \\
5.7 \\
19.4 \\
5.5 \\
6.3 \\
7.3\end{array}$ & $\begin{array}{r}12.84 \\
0.26 \\
14.42 \\
0.12 \\
1.87 \\
112.03 \\
2.36 \\
0.73\end{array}$ \\
\hline \multicolumn{5}{|c|}{$\begin{array}{r}\chi^{2} \text { at P0.05 (d.f. }=1 \text { ): } 3.841 \\
\text { P0.01 (d.f. }=1 \text { ): } 6.635 \\
\text { P0.001 (d.f. }=1 \text { ): } 10.827\end{array}$} \\
\hline
\end{tabular}


In table 12 the number of plants infected with Panama Disease, expressed as a percentage of the total number of available trees, is given for two successive years for either of the two experimental areas. The infection distribution in both trials in the first year after the disease occurred for the first time represented the characteristic pattern of "spontaneous" infection (14) of the disease. SIMMONDs (47) described this pattern as follows: "in a field newly planted with healthy suckers, the disease appears first as scattered single cases; later, new "spontaneous" cases continue to arise accompanied by "associated" infections. These last are contact cases, that occur in immediate juxtaposition to pre-existing "spontaneous" cases. Thus there is a tendency for a number of independent radially spreading patches to occur in the field; ultimately these patches become coalescent by which time the disease is out of control"'.

The complete loss of control of the disease

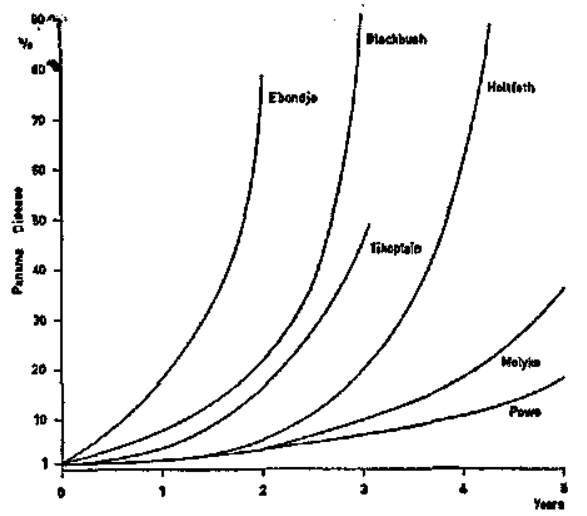

GrapH 5. Spread of Panama Disease. in the Cameroons was found to occur when $10 \%$ or more of the plants in an area had succumbed to the disease (see also graph No. 5). At a percentage disease incidence of between $2 \%$ and $5 \%$ the spread of the disease was by means of new spontaneous cases, above that level also by means of "associated" infections. The latter phase occurred in the second year after the first appearance of the disease in both the experiments. Testing the results of table 12 with the chi-square test, it appeared that several of the treatments had a significant departure from the average disease incidence for the whole of the experimental area. Generally, the fertilized plots had a higher disease incidence than those

which received no fertilizer. Particularly nitrogen but also dressings of potassium alone increased the spread of the disease considerably. The effect of dressings of both $\mathrm{N}$ and $\mathbf{K}$ was equal to or even worse than (owing to a significant interaction between $\mathrm{N}$ and $\mathrm{K}$ ) the sum of the effects of either alone. The incidence of the disease in the plots fertilized with phosphorus alone was comparable with that of the non-fertilized plots, but lower than in the fertilized plots.

It will be seen from the results of table 13, however, that large yield responses were obtained from $\mathrm{K}$ dressings, but that the plants hardly responded to $\mathrm{N}$ and/or $\mathrm{P}$ dressings, unless probably in combinations with $\mathrm{K}$.

These results demonstrated that under the prevailing conditions, that is of bananas growing on soils poorly supplied with nutrients and with a low exchange capacity, large yield responses were obtained from fertilizing, but that the yield increments obtained, particularly those from unbalanced fertilizers, did result in a more rapid, rather than a slower, spread of the disease. Using the increase in mean bunchweight (rather than yield or number of bunches, which, as will be shown later, are prone to losses from various causes) as a measure of the response of the crop to fertilizing, it is obvious that the incidence and spread of the disease was not reduced as a result of improved growth resulting from unbalanced fertilizing (cf. for instance treatment $\mathrm{K}$ with treatment $\mathrm{N}$ in tables 12 and 13). Improved growth resulting from balanced fertilizing, however, did not increase the disease incidence and in some cases even decreased it. The results from tables 12 and 13 suggested that under the mitigating circumstances PK was the best balanced of the fertilizer combinations, certainly in experiment PI. 
TABLE 13. Banana yields in experiments PI and MI.

Experiment P I

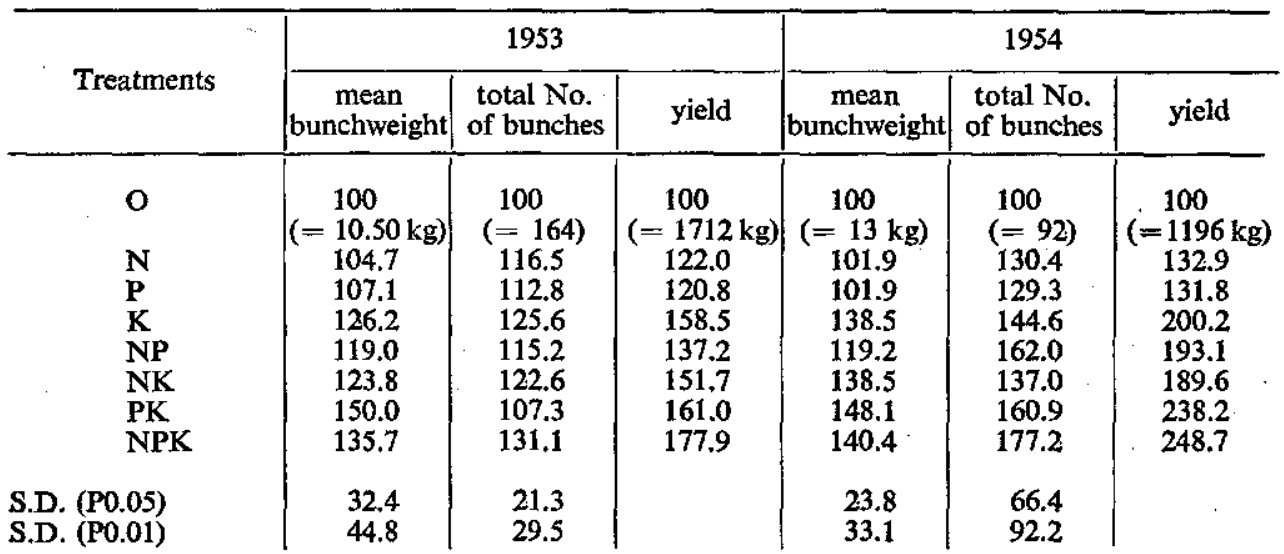

Experiment $\mathrm{MI}$

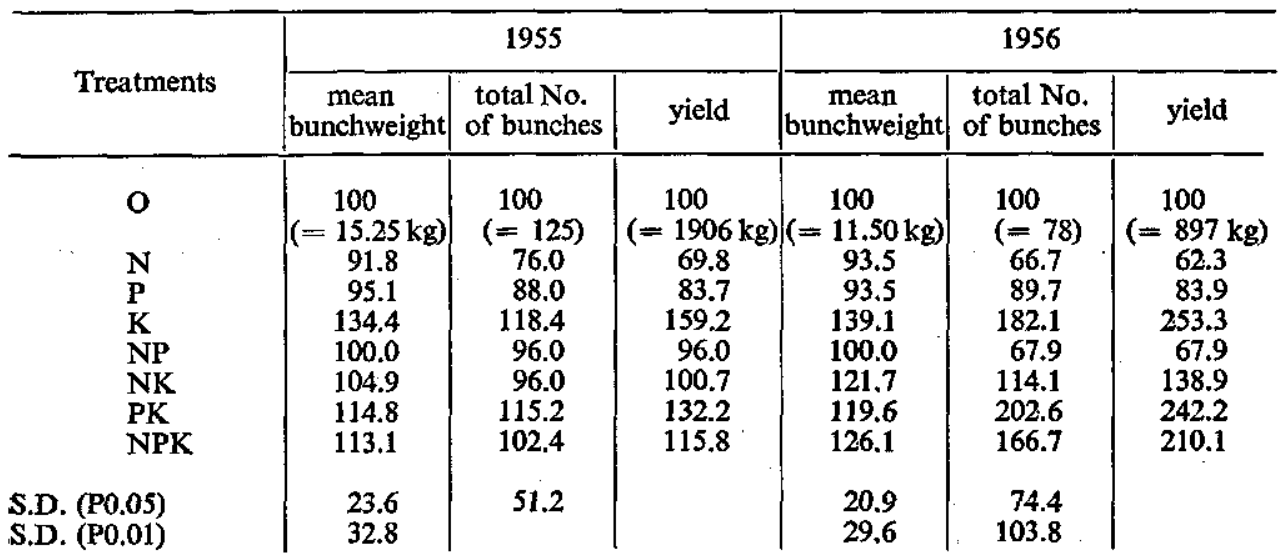

Similar results were obtained in other experiments (cf. 26). They demonstrated that nitrogen was effective only if the plant's $\mathrm{K}$ or PK requirements were met and if the ratio between the applied amounts of $\mathrm{N}$ and $\mathrm{K}$ was correct.

The observations were in line with RISBETH's (41) conclusion that the primary effect of soil fertility on Panama Disease lies in its effect on growth of the banana rather than on the fungus, but they did not necessarily support the general validity of the claim that nitrogenous fertilizers have a detrimental effect on the survival of the host. It should be realised, that most of the work done on this aspect of the disease came from banana growing areas in the western hemisphere, where, with few exceptions, only nitrogenous fertilizers are used (9) on soils well supplied with K or PK. The claim of a favourable effect of $\mathrm{K}$ and/or $\mathrm{P}$ was then deduced from the high $\mathrm{P}$ and $\mathrm{K}$ contents of soils, which had been productive for a long time. In Jamaica, for instance such sites are normally associated with old sugar factory sites, where organic matter had been dumped for many years (47).

The claim of an adverse effect of N-dressings on disease incidence has often been related to the acidifying effect of sulphate of ammonia. This was then based upon the 
observation that highly fertile soils in Central America, which had supported Gros Michel bananas for many years, had a neutral soil reaction. It has led to the belief that a high $\mathrm{pH}$ of itself limits the spread of the disease. That this is not so was shown by SiMMONDS (47), who reported the occurrence of epidemic infection on infertile calcareous soils and by four trials in the Tiko and Ekona areas. In these latter trials liming as a means of increasing the $\mathrm{pH}$ was a treatment. The incidence and subsequent spread of the disease nor the yields in the plots, where the $\mathrm{pH}$ had been raised with at least two units, i.e. from $\mathrm{pH} 4.5$ to 5.5 to $\mathrm{pH} 7$ to 8, differed significantly from that of plots where the $\mathrm{pH}$ had not been raised artifically.

To summarize, the results suggested that the relationship between nutrition and survival of the host was governed by the balance between nutrients rather than by the specific effect of one or another nutrient. From this and from the available literature (47) it might be inferred that the survival of the host is prolonged when growing on a soil with balanced nutrient status and the more so the higher the nutrient status. Probably it was the relationship between the low base saturation and the $\mathrm{pH}$ of a soil that led to the belief of a causal relationship between the $\mathrm{pH}$ and the incidence and spread of the disease.

Referring back to the widely recognized relationship between soil texture and incidence of Panama Disease, much more evidence is required to warrant the claim of it being governed by the complex and differential effect of host and pathogen on fluctuating moisture contents (cf. page $42 \mathrm{sub} \mathrm{3,6}$ and 7). It would be more obvious in the light of the previous results to explain it along the lines of a relationship texture exchange capacity - soil fertility - balanced nutrition. Some examples may endorse the latter view:

a. the occurrence of fluctuating moisture contents in the Cameroons is mainly confined to two distinct periods, i.e. at the beginning and the end of the dry season. The occurrence of Panama Disease is, however, confined to one period only, i.e. the rainy season.

$b$. bananas growing on the generally heavier marine alluvial soils succumbed earlier to Panama Disease than on the lighter young volcanic soils.

c. marine alluvial soils having the same texture, $\mathrm{pH}$ and yield level remained productive longer, when the parent material was of young volcanic origin (Mva-series).

$d$. the lighter and less acid young volcanic ash soils at Tombel, where the dry season is less marked, hence the period of fluctuating soil moisture contents longer (cf. 29) and where devastating tornadoes occur more frequently, remained longer free of Panama Disease, than the heavier and more acid young volcanic soils in the Ekona area.

In so far as the yield of bananas is controlled by soil factors, it is of interest to mention two more aspects, one regarding the interaction between soil and climate, the other in respect of soil and Sigatoka Disease, i.e. a fungal disease infecting the leaves $(38,47)$.

It will be seen from table 14, that drought losses which are caused by the inability of the plant to support the ripening bunch and resulting in breakage of the pseudostem just below the top, amounted to $31 \%$ of the total potential production. There appeared to be large differences in losses between the three soil types of the replications as well as between the fertilizer treatments. Especially the plants treated with potassium had a much lower incidence of drought damage than the average for the experiment (chisquare is 152.0 against 10.83 for chi-square at $\mathbf{P} 0.001$ for one degree of freedom).

Losses resulting from Sigatoka disease consisted of bunches which ripened pre- 
Table 14. Losses and potential production experiment Pungo No. I in 1956.

\begin{tabular}{|c|c|c|c|c|c|c|c|}
\hline \multirow{3}{*}{ Treatments } & \multicolumn{7}{|c|}{ Number of bunches } \\
\hline & \multicolumn{2}{|c|}{ (1) harvested } & \multicolumn{2}{|c|}{ (2) Sigatoka losses } & \multicolumn{2}{|c|}{ (3) drought losses } & \multirow{2}{*}{$\begin{array}{c}\text { (4) Total } \\
\text { potential } \\
\text { production } \\
\text { No. }\end{array}$} \\
\hline & No. & $\%$ of (4) & No. & $\begin{array}{c}\% \text { of } \\
(1)+(2)\end{array}$ & No. & $\%$ of (4) & \\
\hline $\begin{array}{l}\mathbf{O} \\
\mathbf{N} \\
\mathbf{P} \\
\mathrm{K} \\
\mathrm{NP} \\
\mathrm{NK} \\
\mathrm{PK} \\
\mathrm{NPK}\end{array}$ & $\begin{array}{r}49 \\
73 \\
61 \\
132 \\
80 \\
62 \\
137 \\
121\end{array}$ & $\begin{array}{l}32.5 \\
50.3 \\
43.0 \\
85.7 \\
48.5 \\
78.5 \\
85.1 \\
80.7\end{array}$ & $\begin{array}{r}18 \\
8 \\
11 \\
6 \\
14 \\
4 \\
7 \\
9\end{array}$ & $\begin{array}{r}26.9 \\
9.9 \\
15.3 \\
4.3 \\
14.9 \\
6.1 \\
4.9 \\
6.9\end{array}$ & $\begin{array}{l}84 \\
64 \\
70 \\
16 \\
71 \\
13 \\
17 \\
20\end{array}$ & $\begin{array}{l}55.6 \\
44.1 \\
49.3 \\
10.4 \\
45.8 \\
16.5 \\
10.6 \\
13.3\end{array}$ & $\begin{array}{r}151 \\
145 \\
142 \\
154 \\
165 \\
79 \\
161 \\
150\end{array}$ \\
\hline Total or Mean & 715 & 62.3 & 77 & 9.7 & 355 & 31.0 & 1147 \\
\hline $\begin{array}{r}\text { Replication } \\
\text { A } \\
\text { B } \\
\text { C }\end{array}$ & $\begin{array}{l}303 \\
227 \\
185\end{array}$ & $\begin{array}{l}74.3 \\
63.1 \\
48.8\end{array}$ & $\begin{array}{l}21 \\
28 \\
28\end{array}$ & $\begin{array}{r}6.5 \\
11.0 \\
24.8\end{array}$ & $\begin{array}{r}84 \\
105 \\
166\end{array}$ & $\begin{array}{l}20.6 \\
29.2 \\
43.8\end{array}$ & $\begin{array}{l}408 \\
360 \\
379\end{array}$ \\
\hline
\end{tabular}

maturely owing to a reduction in leaf area available for photosynthesis. Since drought losses eliminated Sigatoka losses the latter were not tested against the potential number of bunches but against the number of bunches actually harvested. Testing of individual treatments with the chi-square test on the average incidence of Sigatoka losses revealed that only the control plots departed significantly from the average incidence. Apparently fertilizing reduced the effect of Sigatoka leaf infection on the number of "green ripe" bunches. It was striking, however, that all the $\mathrm{K}$ treated plots had a negative deviation from the mean incidence, while the plots without $\mathrm{K}$ had a positive deviation. The main effect of $\mathbf{K}$ was indeed found to be highly significant ( $P$ 0.001). In this experiment on marine alluvial soil (Ms-series) $\mathrm{K}$ fertilizing very significantly reduced $a$. drought losses from $48 \%$ to $12 \%, b$. Sigatoka losses from $16 \%$ to $5 \%$ and $c$. total losses from $56 \%$ to $17 \%$. The effect of differences in profile characteristics between replications $\mathrm{A}$ and $\mathrm{C}$ amounted to a reduction $a$. in drought losses from $44 \%$ to $21 \%, b$. in Sigatoka losses from $13 \%$ to $6 \%$ and $c$. in total losses from $51 \%$ to $26 \%$.

In the foregoing pages the results obtained from banana fertilizer trials situated on marine alluvial soils were discussed in relation to the potential suitability of a soil to grow bananas in monoculture on a plantation basis, and were compared with the experience gained elsewhere. This latter experience was compiled by SIMMONDs (47), who concluded that there are three factors which decide whether a soil can be made to grow bananas: 1. structure: "which determines whether or not it has adequate internal drainage", 2. depth "which may be regarded as an aspect of structure" and 3. presence or absence of toxic substances.

From these and other (cf. next paragraph on young volcanic soils) considerations, the conclusion was drawn that the most important factor determining the suitability of a soil for growing bananas is the volume of soil available for rooting, while the suitability class of a soil in relation to its rooting volume is governed by the following factors: 
a. climatical factors: the more pronounced the seasonal fluctuations, the larger the rooting volume should be.

$b$. the texture of a soil: soils heavier or lighter than the optimum under a given set of conditions require a larger rooting volume and the more so the more pronounced the seasonal fiuctuations, owing to their effect on the drainage condition and water retaining capacity of the soil respectively.

c. the exchange capacity of a soil: the smaller the exchange capacity, the larger the rooting volume should be in order to ensure a constant and sufficient supply of nutrients throughout the year and in so far as humic compounds co-determine the exchange capacity to ensure the water and nitrogen supply of the soil.

$d$. the base saturation of the adsorption complex of a soil: the lower the $\mathrm{pH}$ at a certain exchange capacity the larger the rooting volume should be.

$e$. the type of clay mineral in its effect on fixation and relative distribution of nutrients, and on swelling and shrinkage of a soil: generally the more marked the effect of type of clay mineral, particularly if enhanced by pronounced seasonal fluctuations, the larger the rooting volume should be.

$f$. the nutrient supplying power of a soil: the smaller and the more unbalanced the nutrient supplying power of a soil the larger its rooting volume should be.

$g$. the clone grown: the less tolerant a banana clone to adverse environmental conditions, such as diseases, nutrient supply and climatic conditions, the larger the rooting volume should be.

$h$. the variability of the soils in a given area: the greater the deviations are from the weighted mean suitability of an area, the lower its actual suitability. For, the larger the number of pockets prone to adverse environmental conditions such as diseases and wind damage, the greater the threat of spreading to surrounding good sites. This concept can be further refined, for instance to the extent of the size of the rock fragments. The suitability of an area with a given rooting volume will decrease with increasing size of the rock fragments. This can become a major consideration in assessing the suitability of different types of deposits by volcanic flows.

The varying incidence of the factors just mentioned causes a wide range of interactions. These latter will become even more complex by attempts to improve on a given set of conditions, for instance by means of fertilizing. It was shown previously that a favourable effect of a treatment on one factor, for instance from K-dressings on Sigatoka disease, does not preclude the possibility of it having an adverse effect on another factor, e.g. On the incidence and spread of Panama Disease owing to the unbalancedness of dressings of $\mathrm{K}$ alone.

The presence of so many imponderables also implies that it is impossible to give a definition of a good banana soil. Generalizations in the latter respect will provoke serious criticism, as for instance expressed by CHARTER (12) in connection with the practice of discovering virgin lands, which can initially support bananas with the minimum of cultivation and manuring, rather than of a proper assessment of their capabilities for enduring land use. Similarly, the validity on a longer term of the statement by BUTLER (9) could be criticised, i.e. that the profitability of fertilizing bananas on the continent of South and Central America is dependent on one nutrient only, viz. nitrogen. The application of this fertilizer practice to the Cameroons in any case has had disastrous effects, even if short term profits may have been derived from this practice at the expense of the long term profits that could have been derived from the land.

Evidence for the latter, apart from that produced in many experimental areas, discussed previously, and in the Cameroun Republic $(14,37)$ on soils very akin to the 
young volcanic soils of the Cameroon Mountain, was also provided by the production figures for the Corporation's banana plantations (cf. Cameroons Development Corporation Annual Reports 1957 and 1958). Prior to 1954 only nitrogenous fertilizers were used, since the end of 1954 balanced NPK (10-9-29) compound fertilizers (cf. also 26) at the rate of $8 \mathrm{cwts}$ per acre per annum and since 1957 at the rate of $12 \mathrm{cwts}$ (cf. table 15).

TABLE 15. C.D.C. banana production 1952-1958.

\begin{tabular}{|c|c|c|c|c|c|c|c|c|c|c|c|c|}
\hline \multirow[b]{2}{*}{ Year } & \multirow[b]{2}{*}{ Acreage } & \multicolumn{2}{|c|}{$\begin{array}{c}\% \text { of total } \\
\text { acreage situed on: }\end{array}$} & \multicolumn{2}{|c|}{ shipments } & \multirow[b]{2}{*}{ bunches } & \multicolumn{3}{|c|}{ Yield per acre*** } & \multicolumn{3}{|c|}{ Moan bunchweight*** } \\
\hline & & $\begin{array}{c}\text { Marine } \\
\text { alluvium }\end{array}$ & $\begin{array}{c}\text { Young } \\
\text { volcanic } \\
\text { soils }\end{array}$ & bunches & tons & & tons & $\begin{array}{c}1952-54 \\
=100\end{array}$ & $\begin{array}{c}\text { adjusted } \\
1952-54 \\
=100\end{array}$ & Ibs & $\begin{array}{c}1952-54 \\
=100\end{array}$ & $\begin{array}{c}\text { adjusted } \\
1952-154 \\
=100\end{array}$ \\
\hline $\begin{array}{l}1952 \\
1953 \\
1954\end{array}$ & $\begin{array}{l}19282 \\
20189 \\
22212\end{array}$ & $\begin{array}{l}46 \\
47 \\
45\end{array}$ & $\begin{array}{l}54 \\
53 \\
55\end{array}$ & $\begin{array}{l}3743801 \\
3846585 \\
3904863\end{array}$ & $\begin{array}{l}46288 \\
54077 \\
52739\end{array}$ & $\begin{array}{l}194 \\
191 \\
176\end{array}$ & $\begin{array}{l}2.4 \\
2.7 \\
2.4\end{array}$ & 100 & 100 & $\begin{array}{l}27.7 \\
31.5 \\
30.3\end{array}$ & 100 & 100 \\
\hline $\begin{array}{l}1955^{*} \\
1956\end{array}$ & $\begin{array}{l}22963 \\
18670\end{array}$ & $\begin{array}{l}43 \\
42\end{array}$ & $\begin{array}{l}57 \\
58\end{array}$ & $\begin{array}{l}3034222 \\
3074397\end{array}$ & $\begin{array}{l}45539 \\
47751\end{array}$ & $\begin{array}{l}132 \\
165\end{array}$ & $\begin{array}{l}2.0 \\
2.6\end{array}$ & $\begin{array}{r}80 \\
108\end{array}$ & $\begin{array}{l}111 \\
139\end{array}$ & $\begin{array}{l}33.6 \\
34.8\end{array}$ & $\begin{array}{l}113 \\
117\end{array}$ & $\begin{array}{l}120 \\
124\end{array}$ \\
\hline $\begin{array}{l}1957 \\
1958\end{array}$ & $\begin{array}{l}14912 * * \\
14262\end{array}$ & $\begin{array}{l}38 \\
38\end{array}$ & $\begin{array}{l}62 \\
62\end{array}$ & $\mid \begin{array}{l}3121268 \\
3011115\end{array}$ & $\begin{array}{l}53511 \\
53831\end{array}$ & $\begin{array}{l}209 \\
211\end{array}$ & $\begin{array}{l}3.6 \\
3.8\end{array}$ & $\begin{array}{l}144 \\
152\end{array}$ & $\begin{array}{l}155 \\
163\end{array}$ & $\begin{array}{l}38.4 \\
40.0\end{array}$ & $\begin{array}{l}129 \\
134\end{array}$ & $\begin{array}{l}127 \\
132\end{array}$ \\
\hline
\end{tabular}

* year of serious winddamage.

** acreage in care and maintenance not taken into account.

*** for explanation of adjusted columns see text.

It will be seen from table 15 that the yields per acre increased considerably as from 1955. A better picture still was provided by the mean bunchweights, which are not influenced to the same extent by the effect of windstorms and which steadily increased by more than $30 \%$ compared with the average weight during the period 1952-1955. It might be argued, however, that this increase was not necessarily caused by fertilizing alone, because during the period under consideration there were several factors which were known to have influenced the shipped yields per acre considerably. One of these factors was the gradual increase in the proportion of the cultivated area situated on young volcanic soils. Even if a difference in mean bunchweights of $50 \%$ were allowed in favour of the young volcanic soils, the effect of the shift towards the volcanic soils on the mean bunchweight increase would have amounted to not more than $3 \%$ out of the total increase of $34 \%$ obtained in 1958 in relation to the period 1952-1955.

Two other factors which affected the figures of table 15 were Sigatoka disease, which appeared at the end of 1954 (39), and the marketability of the fruit (bunches with 6 hands not being so readily accepted anymore since 1955 ).

The effect of the latter on shipped yield per acre and on shipped mean bunchweight was worked out by SANDERS (42). Owing to the non-shippability of 6 hand bunches, and taking 1954 as the basis of comparison, the Cameroons Development Corporation yields shipped per acre and the mean bunchweights of the shipped fruit decreased and increased respectively by $7 \%$ in 1955 and 1956 . This figure was $4 \%$ in 1957 and 1958 .

HASSELO (23) showed that the adverse effect of Sigatoka leaf infection during 1955 and 1956 on yield and bunchweight amounted to approximately $25 \%$ and $15 \%$ respectively, while control of Sigatoka disease during 1957 and 1958 by oil spraying was shown by PRICE (40) to reduce the yields and bunchweights by approximately $10 \%$ and $5 \%$ respectively. 
The adjusted percentage increases in bunchweight and yield were shown in the adjusted columns of table 15 , and were computed in the way shown in table 16.

TABLE 16. Adjusted \% increase in yield/acre and bunchweight.

\begin{tabular}{|c|c|c|c|c|c|}
\hline \multirow{2}{*}{ Year } & \multirow{2}{*}{\begin{tabular}{|} 
Yield increase actual \\
$(\%$ of period \\
$1952-1955)$
\end{tabular}} & \multicolumn{3}{|c|}{ Yield per acre adjustments } & \multirow{2}{*}{$\begin{array}{c}\text { Potential yield } \\
\text { increase } \\
(\% \text { of } 1952-1955)\end{array}$} \\
\hline & & (a) & (b) & (c) & \\
\hline $\begin{array}{l}1955 \\
1956 \\
1957 \\
1958\end{array}$ & $\begin{array}{l}80^{*} \\
108 \\
144 \\
152\end{array}$ & $\begin{array}{l}+7 \\
+7 \\
+4 \\
+4\end{array}$ & $\begin{array}{l}+25 \\
+25 \\
+10 \\
+10\end{array}$ & $\begin{array}{l}-1 \\
-1 \\
-3 \\
-3\end{array}$ & $\begin{array}{l}111 \\
139 \\
155 \\
163\end{array}$ \\
\hline \multirow{2}{*}{ Year } & \multirow{2}{*}{$\begin{array}{c}\text { Bunchweight } \\
\text { increase actual } \\
\text { (\% of period) } \\
1952-1955)\end{array}$} & \multicolumn{3}{|c|}{ Mean bunchweight adjustments } & $\begin{array}{c}\text { Potential } \\
\text { bunchweight }\end{array}$ \\
\hline & & (a) & (b) & (c) & $\begin{array}{c}\text { mncrease } \\
(\% \text { of } 1952-1955)\end{array}$ \\
\hline $\begin{array}{l}1955 \\
1956 \\
1957 \\
1958\end{array}$ & $\begin{array}{l}113^{*} \\
117 \\
129 \\
134\end{array}$ & $\begin{array}{l}-7 \\
-7 \\
-4 \\
-4\end{array}$ & $\begin{array}{l}+15 \\
+15 \\
+5 \\
+5\end{array}$ & $\begin{array}{l}-1 \\
-1 \\
-3 \\
-3\end{array}$ & $\begin{array}{l}120 \\
124 \\
127 \\
132\end{array}$ \\
\hline
\end{tabular}

* cf. table 15.

(a) = effect of marketability.

(b) = effect of Sigatoka.

(c) = effect of shift to more fertile young volcanic soils.

Although it is impossible to determine exactly the effect of the various factors influencing the banana yields of the Corporation, the adjustments shown in table 16 were the main factors, whose effects were based upon experimental results. The results demonstrated that after the introduction of balanced NPK compound fertilizers the yields and mean bunchweights of the Corporation's lands increased considerably, i.e. by $63 \%$ and $32 \%$ respectively in 1958 compared with the average of the period $1952-$ 1955 , when only nitrogenous fertilizers were applied. These percentage increases were $55 \%$ and $27 \%$ for $1957,39 \%$ and $24 \%$ for 1956 , and $11 \%$ and $20 \%$ for the blowdown year 1955 respectively.

It would appear also from the trend of the yield increases obtained with dressings of 8 and 12 cwts NPK fertilizer, that the optimum yield response was not yet attained from dressings of 12 cwts per acre per annum, the optimum dressing being nearer to 16 cwts.

Another interesting result was that in years with little winddamage and other adverse influences, the percentage yield increase was twice as large as that for mean bunchweight, cf. $1957: \frac{55 \%}{27 \%}=2$ and $1958: \frac{63 \%}{32 \%}=2$. This factor two was consistently found in the experimental areas. For instance, the mean percentage increase in bunchweight of the fertilized plots as compared with the control plots in experiment P I (cf. table 13) amounted to $25 \%$ in 1953, whereas the mean percentage increase in yield amounted to $48 \%$. In the following years $(1954,1955,1956)$ losses in the control plots were too high (cf. table 14) to enable a fair comparison. This was also the case in 1956 in experiment M I. In 1955, however, the mean percentage increase in bunchweight and yield in the four $\mathrm{K}$ treatments as compared with the control plots was $18 \%$ and $28 \%$ respectively. Taking into account the higher incidence of Panama Disease in 
the K-fertilized plots (cf. table 12 ) these figures became $18 \%$ and $34 \%$ respectively. It means that if a certain percentage increase in bunchweight was obtained from for instance fertilizing it may be safely assumed that the percentage yield increase will be twice that amount. If this increase with a factor 2 is not obtained, it is due to factors like marketability of the fruit, wind damage and diseases, but also to bad harvesting and low quality of the fruit. It was not due to quicker growth of the plants as a result of fertilizing, since a significantly increased growth rate was seldom obtained in the many fertilizer trials laid down since 1952.

\section{Young volcanic soils}

In the previous paragraph the incidence and spread of Panama Disease was discussed in relation to the suitability of marine alluvial soils for growing Gros Michel bananas.

In graph No. 5 the spread of the disease is shown for banana plantations situated on different soils, i.e. on shallow marine alluvial soils (Ms-series) in the Tiko plain (Blackbush and Ebondje sections situated below 120' above M.S.L.), on marine alluvium consisting of young volcanic parent material (Mva-series) also in the Tiko plain (Holtfoth section situated between $40^{\prime}$ and $120^{\prime}$ above M.S.L.), for the entire C.D.C. area planted with bananas in the Tiko plain, for Molyko near Muea, a plantation situated between $1500^{\prime}$ and $2200^{\prime}$ above M.S.L. on young volcanic soil (Va-series), and for the Powo plantation situated N.E. of Ekona also on young volcanic soil (Vaseries) but between $600^{\prime}$ and $900^{\prime}$ above M.S.L.

It will be seen from the graph that the spread, i.e. as from the point the percentage losses reached the $1 \%$ level (year 0 on the graph) is very much slower on the soils consisting of young volcanic material.

Adding to it the difference in time required (not shown on the graph) to reach this $1 \%$ level, which was for instance 3 years after planting in Blackbush and more than 20 years in Powo it is clear how large the difference can be in life time of a banana plantation, consequently its profitability.

The characteristic pattern of occurrence of the disease, discussed previously would appear to be by "spontaneous" infection up to a level of between $1 \%$ and $5 \%$, depending upon the "resistance" of the soil, "associated" infections playing an increasingly important role above that level up to approximately $10 \%$. As from the latter percentage infection level control of the disease is completely lost irrespective of the soil type.

If related to the results of table 10 (chemical composition) and table 7 (profile descriptions of marine alluvial and volcanic soils), the difference in disease pattern between young volcanic and marine alluvial soils (Ms-series) would appear to be principally due to the larger fertility of the former.

It was seen in the previous paragraph that there were both direct and indirect effects of fertilizing (and profile characteristics) on the yield. The indirect effects were shown to account for half the potential yield increase.

One of the indirect effects not yet discussed was that on the tolerance of the plants to wind damage. It will be seen from table 17 that fertilizing had a definite influence on the proportion of trees damaged, $N$ and $K$ dressings decreasing and increasing respectively the tolerance of the plants to winddamage. The most favourable ratio between $\mathrm{N}$ and $\mathrm{K}_{2} \mathrm{O}$ was found to be between $1: 3$ and $1: 5$ (cf. 26).

Owing to the fact that also on young volcanic soils large responses were obtained from fertilizers with the same ratio between the different nutrients, it would appear reasonable to assume that the largest single factor contributing to the difference in 
TABLE 17. Number of plants lost to winddamage in 1956 (total of 4 experiments in the Ekona area).

\begin{tabular}{l|c|c|c|c|c|c}
\hline & \multicolumn{3}{|c|}{ high $N$-dressings } & \multicolumn{3}{c}{ low N-dressings } \\
\cline { 2 - 7 } \cline { 5 - 7 } & observed & expected & $\chi^{2}$ & observed & expected & $\chi^{2}$ \\
\hline damaged.... & 226 & 196 & 4.59 & 166 & 196 & 4.59 \\
not damaged . & 1814 & 1844 & 0.49 & 1874 & 1844 & 0.49
\end{tabular}

total chi-square: 10.16 (P0.01: 6.635).

\begin{tabular}{l|c|c|c|c|c|c}
\hline & \multicolumn{3}{|c|}{ high K-dressings } & \multicolumn{3}{c}{ low K-dressings } \\
\cline { 2 - 7 } & observed & expected & $\chi^{2}$ & observed & expected & $\chi^{2}$ \\
\hline damaged ... & 170 & 211 & 9.29 & 2.22 & 181 & 7.67 \\
not damaged . & 2036 & 1995 & 0.98 & 1674 & 1715 & 0.84
\end{tabular}

total chi-square: 18.78 (P0.01: 6.635).

suitability of marine alluvial and young volcanic soils is the difference in exchange capacity.

Owing to their larger exchange capacity in particular and their high fertility in general, the young volcanic soils are more suitable for growing bananas than the marine alluvial soils (Ms-series), provided, of course, the profiles of both types of soil have comparable rooting volumes.

It will be seen from table 18 that rooting volume was also the major factor in respect of the productivity of a young volcanic soil.

The four replications of a fertilizer experiment at Muea on young volcanic soil represented four types of soil, which differed in their profile depth. The mean number of hands per bunch for three successive generations of plants not only differed with depth of soil, but also showed correspondingly larger variations around the mean. Thus, the effect of seasonal variations was larger the shallower the soil.

The evidence produced by the results supported the conclusions drawn by French investigators regarding the suitability of the soils for growing bananas in the Ivory Coast and in Guinea $(11,13)$. The latter soils would compare best with the marine alluvial soils of the Cameroons (Ms-series) and are planted with a Panama Disease resistant banana variety. DABIN and LENEUF (13) stated the following regarding the organic matter content of the Ivory Coast soils:

"Il n'est pas possible de comparer au point de vue fertilité les teneurs en matière organique d'un sol bien drainé et à $\mathrm{pH}=6$ et d'un sol inondé et à $\mathrm{pH}=4.5$. Par contre deux sols normalement drainés et possédant le même $\mathrm{pH}$ sont tout à fait comparables dans les intervalles que nous avons définis (intervals in \% organic matter content) et pour un rapport $\mathrm{C} / \mathrm{N}$ voisin de 10 . Inversement pour une même teneur en matière organique et pour un drainage correct la fertilité sera d'autant plus élevée que le $\mathrm{pH}$ sera lui-même plus élevée" and further on: "le rendement des bananeraies... peut doubler entre pH 4.5 et 6 ; nous avons montré en revanche que la richesse en azote du sol pouvait, dans une certaine mésure, compenser l'acidité."

These results were in line with the experience described here, the difference being principally a matter of accentuation. Thus, rather than stressing the $\mathrm{pH}$ itself as the causative agent for differences in suitability, it would appear to be more relevant in the light of our results to consider the $\mathrm{pH}$ as a correlative factor, reflecting differences of 


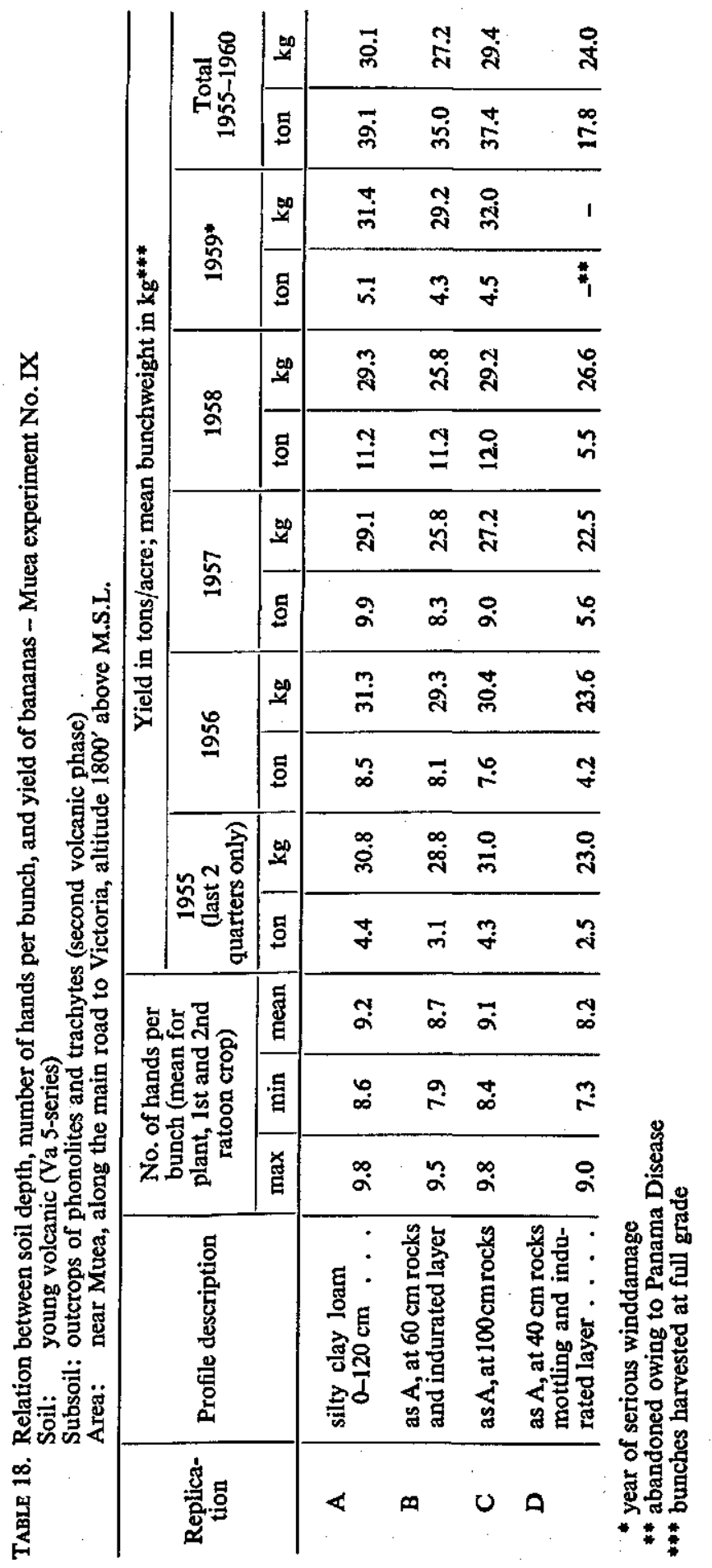


the soil characteristics proper. The statement in respect of the relation between $N$ supply and acidity of the soil could then be regarded as a reflection of interactions between soil organic matter content, in its effect upon nutrient availability and exchange capacity, and base saturation of the adsorption complex. The importance attached in the Ivory Coast to organic manuring (up to 60 tons green manure per acre) is not surprising in the light of the low exchange capacity of the soils, indeed it should be considered as one of the major conditions to ensure prolonged productivity of such soils, notwithstanding large fertilizer applications and the practice of irrigation.

In this context, it was of interest to note that DUGAIN (14) studying the growth of bananas on the young volcanic soils of the Cameroun Republic near Tombel (cf. table 10), established the following relationships: the larger the clay content, or generally the more weathered the soil, $a$. the lower the organic matter content, $b$. the lower the exchange capacity, and $c$. the smaller the exchangeable K-content of the soil. Furthermore, the higher the organic matter content, the larger the exchange capacity. This author was unable to demonstrate a correlation between the growth of bananas and the organic matter content and the clay content respectively. These latter findings should however not preclude the existence of a significant relationship, because this author omitted to work out a partial correlation in order to eliminate the disturbing influence of the correlation between organic matter and clay content.

The importance of the soil organic matter content of a soil in

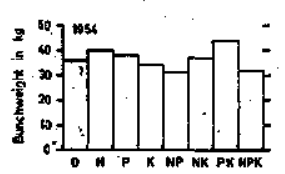
relation to its suitability for growing bananas, was also inferred from the results of a fertilizer experiment (with the same design as Pungo No. I) situated at Old Koke near Ekona. The area consisted of a rather badly drained and heavy young volcanic soil, which prior to planting was cleared from secondary forest (graph 6). The rapid decline in yield, as expressed by the mean
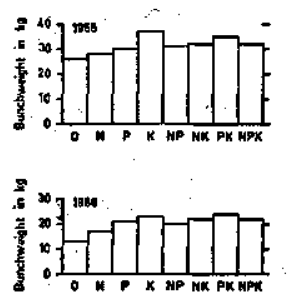
bunchweight, might be safely attributed to the rapidly decreasing effect of decaying forest litter, also because the decline was only partially offset by artificial manuring.

To summarize, there appeared to be a close soil-crop relationship in bananas, which, as far as can be ascertained, has received little attention until very recently, certainly if compared with the considerable progress made in other aspects of the cultivation fo bananas, such as disease control, irrigation and drainage. The

GraPH 6

Old Koke experiment no. I.

Mean bunchweight (in $\mathrm{kg}$ full grade)

results clearly indicated the importance of making a soil inventory of an area, prior to it being planted with bananas. Comparatively slight differences in profile characteristics of a soil caused large differences in yield and productive period of a plantation, and governed to a large extent the effect of adverse environmental conditions on the difference between potential and actual yield, for instance as a result of the effect of Sigatoka leaf spot disease and its control by oil spraying, drought and winddamage and deterioration of quality of the produced fruit.

\section{SOIL-CROP RELATIONSHIPS IN OIL PALMS}

The oil palm estates of the Cameroons Development Corporation are situated on marine alluvial soils in the M'Pundu (Ms-series) and Bota-Victoria areas (Mvr-series), on old volcanic soils (Vt-series) in the Moliwe area and on rocky young volcanic soils (Vr-series) in the Bota area.

The previously mentioned factors, which determined the suitability of a soil for 


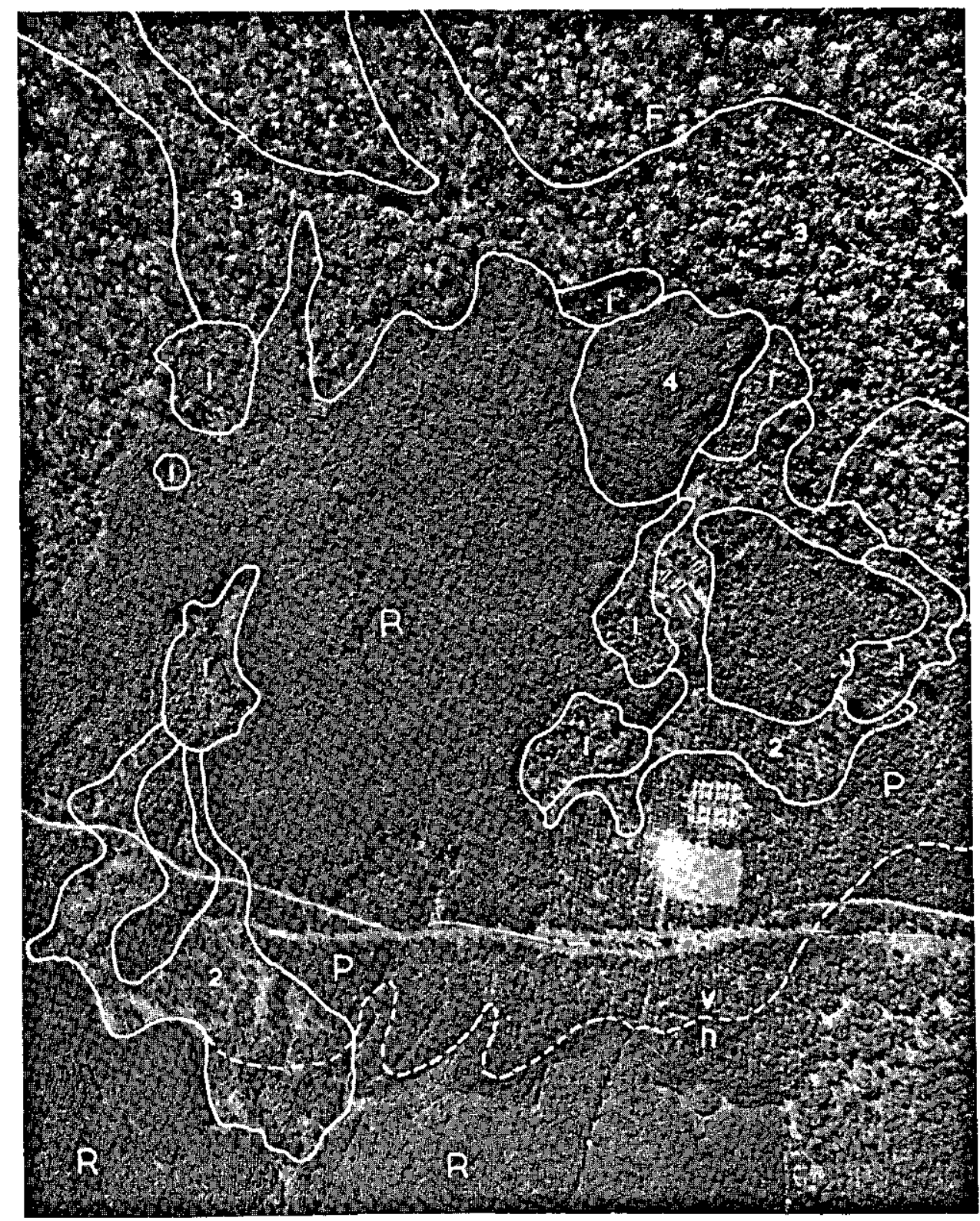

Plate 2. Meanja - area (scale $1: 13,000$ ) - March 1956
1. Swamps at the front of volcanic flows
2. Shallow soils (note vacancies in oil palms)
3. Very recent lava flow
4. Old volcanic outcrop
P. Oil palms
R. Rubber
F. Forest
F. - boundary between volcanic (v) and non-volcanic (n) soils 


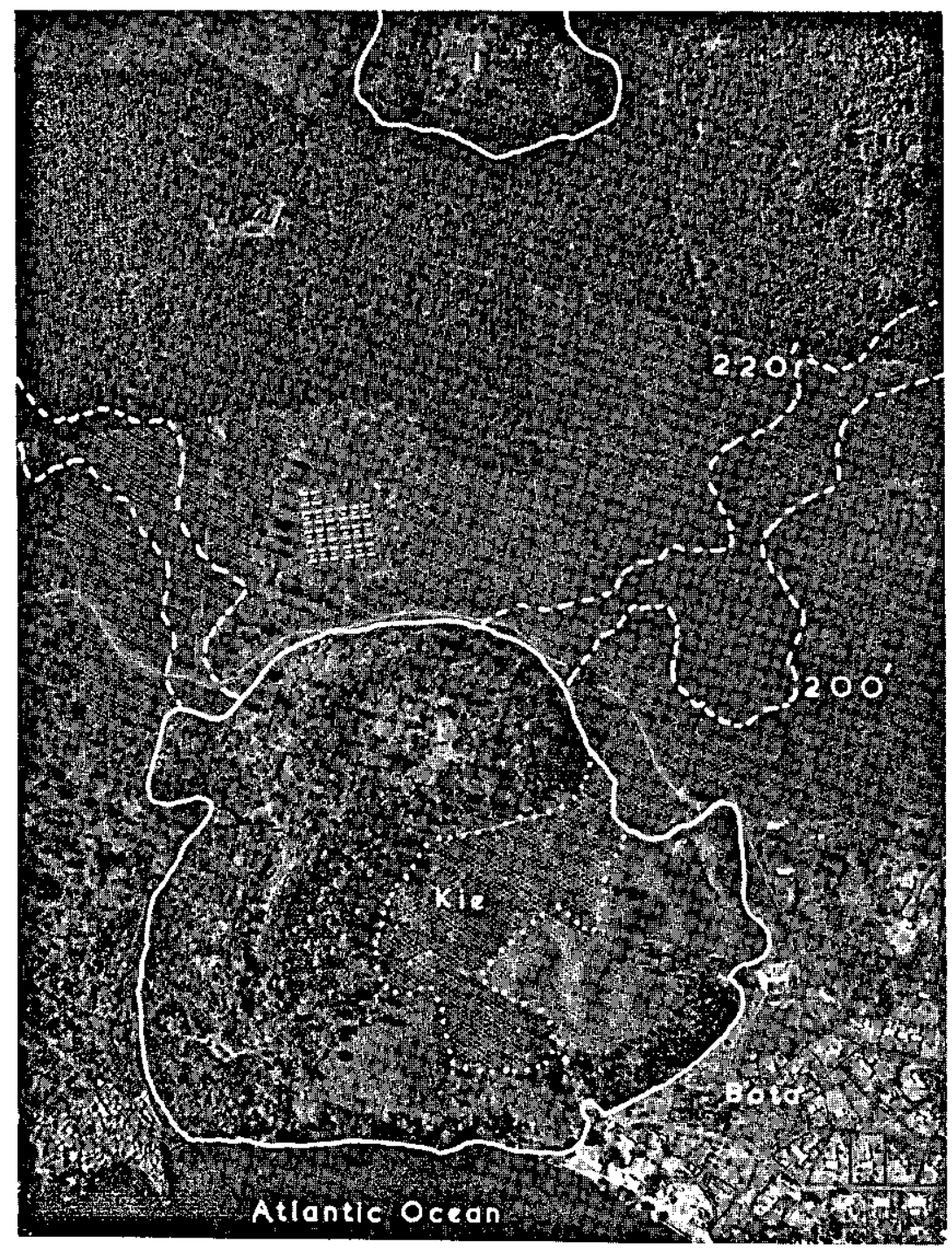

Plate 3. Bota-Kie area (scale 1:13,000) - March 1956

1. Relic craters

- - - contour lines (note vacancies in replanted oilpalms between contour lines)

.... area of Vascular Wilt disease (note vacancies in oilpalms replanted in 1952) 
growing bananas, apply also to oil palms, the available rooting volume being of primary importance. The shallower the soil, the shorter the life expectation, hence productive period, of the plant. The aerial photographs clearly showed that the number of vacancies in areas with old palms was much larger on shallow, very sandy or rocky soils (cf. plate 2).

The results of a fertilizer experiment with young oil palms in the M'Pundu area (Ms-series) were reported elsewhere (24). They demonstrated that the responses of oil palms were principally the same as those in respect of bananas, namely that the fertility status of marine alluvial soils (Ms-series) was low, but at that low level, well balanced. Although initially responses in vegetative growth were obtained from unbalanced fertilizers, particularly $\mathrm{N}$ or $\mathrm{K}$ or NK, these latter did not affect reproductive growth to the same extent or even had an adverse effect. In analogy to the effect on incidence of Panama Disease in bananas, the incidence of Crown Disease, a physiological disorder affecting the growth of young oil palms, was more widespread in plots receiving unbalanced fertilizers. It was demonstrated for instance (24) that the vegetative growth of young oil palms was favourably affected by K-dressings, but that, when they entered the reproductive stage, the sex ratio of the inflorescences and the incidence of Crown Disease were adversely affected, particularly in the absence of magnesium dressings. It would appear, therefore, that the more important aspect of fertilizing was that of the balance between the applied nutrients, rather than that of the responses obtained from each nutrient alone. It was concluded from the analysis of growth responses and leaf analysis, that conditions for maximal growth were not necessarily the same for optimal growth and maximal production.

The yields obtained in this fertilizer trial since then, i.e. during the first 18 months of production suggested that a $1 \%$ higher incidence of Crown Disease in an area corresponded with a decrease in yield of approximately $1 \%$, and this for instance notwithstanding the fact that the badly Crown Disease affected palms treated with $\mathrm{K}$ had responded to $\mathrm{K}$-dressings with a significant increase in bunchweight of $11 \%$. So it would appear, that the retardation in growth caused by Crown Disease mainly affected the production of female flowers, whose initiation and differentiation is determined in a period 2 to 3 years prior to that which determines the ultimate weight of the bunch (48).

As regards the soils consisting of young volcanic parent material in the Bota area (Mvr and Vr-series), the redisposition of the finer material of the lava soils (Vr-series) under the influence of marine action (Mvr-series) had two effects namely the formation of soils more and less rocky, hence less and more suitable respectively, than the average lava soil. The rocky phases were predominantly encountered along the old beach lines, i.e. at levels of $120^{\prime}, 220^{\prime}$ and $300^{\prime}$ above M.S.L. (cf. plate 3). The effect of these latter soils on the productivity of the land was reflected by a larger number of vacancies in areas with old pre-war palms and by a more irregular growth and lower yield of the recently replanted areas (34) (table 19$)$.

TABLE 19. Fruit yields of replanted oil palm areas at Bota (Mvr-series).

\begin{tabular}{|c|c|c|c|c|c|c|c|c|c|c|c|}
\hline \multirow{3}{*}{ Area } & \multirow{3}{*}{$\begin{array}{l}\text { Year of } \\
\text { planting }\end{array}$} & \multirow{3}{*}{ Acreage } & \multirow{3}{*}{$\begin{array}{c}\text { Rockiness of } \\
\text { the soil }\end{array}$} & \multicolumn{4}{|c|}{ Yield/acre } & \multirow{2}{*}{\multicolumn{2}{|c|}{$\begin{array}{l}\text { Bunches/ } \\
\text { acre }\end{array}$}} & \multirow{2}{*}{\multicolumn{2}{|c|}{$\begin{array}{l}\text { Mean } \\
\text { bunchwt. } \\
\text { (Ibs) }\end{array}$}} \\
\hline & & & & \multicolumn{2}{|c|}{1958} & \multicolumn{2}{|c|}{1959} & & & & \\
\hline & & & & tons & $\%$ & tons & $\%$ & 1958 & 1959 & 1958 & 1959 \\
\hline $\begin{array}{l}\text { Mokundange } \\
\text { Middle Farm } \\
\text { Limbe }\end{array}$ & $\begin{array}{l}1953 \\
1953 \\
1953\end{array}$ & $\begin{array}{r}46 \\
97 \\
108\end{array}$ & $\begin{array}{l}\text { slightly rocky } \\
\text { rocky } \\
\text { very rocky }\end{array}$ & $\begin{array}{l}3.1 \\
2.4 \\
1.2\end{array}$ & $\begin{array}{l}258 \\
200 \\
100\end{array}$ & $\begin{array}{l}3.4 \\
3.1 \\
1.3\end{array}$ & $\begin{array}{l}262 \\
238 \\
100\end{array}$ & $\begin{array}{l}473 \\
396 \\
203\end{array}$ & $\begin{array}{l}468 \\
356 \\
209\end{array}$ & $\begin{array}{l}14.5 \\
13.3 \\
13.6\end{array}$ & $\begin{array}{l}15.7 \\
16.8 \\
13.4\end{array}$ \\
\hline
\end{tabular}


These areas received exactly the same fertilizer applications. Yields differed, however, to the extent of more than $250 \%$. It will be seen from the figures of table 19 , that these differences were caused mainly by the number of bunches produced, bunchweight playing a relatively unimportant role. Differences in number of bunches is a matter of the number of female flowers formed, in other words sex ratio. Studies carried out by BROEKMANS (8), SPARNAAIJ (48) and BREDAS and ScuVIE (7) conclusively' showed that sex ratio is closely related to sunshine. Thus the dry season is mainly responsible for high sex ratios, consequently large bunch yields. The number of hours of sunshine and the rainfall is the same in the three areas mentioned in table 19 (3). The next important factor in the determination of the sex ratio is the amount of rainfall in the dry season (8), or generally the available soil moisture supplies during the dry season.

Since there are no real differences in soil texture of the three areas, it is clear that the less rocky soil has the larger water retaining capacity. From this it was inferred that the effect of rockiness on yield was largely one of availability of water during periods of much sunshine, i.e. the dry season.

Under these conditions it would appear obvious to relate the outstanding role of $\mathrm{K}$ at least partly also to its effect on the regulation of the water economy and photosynthesis of the plants. ZILLER (51) arrived at a similar conclusion in a detailed study of the effect of $K$ on copra contents of coconuts: the effect of $K$ was found to be more marked when the fruit ripened in periods of much sunshine. This author suggested a relationship between the effect of $\mathrm{K}$ and photosynthesis.

Evidence for it was also supplied by the results from fertilizer trials in rubber (25), and the lower $\mathrm{K}$-contents found by chemical analysis of leaves of Lacatan bananas (26) and oil palms (28) in the dry season.

It was found that leaf nutrient contents other than $\mathbf{K}$ were also subject to seasonal variations (table 20).

TABle 20. P-contents of youngest fully developed leaf M'Pundu fertilizer experiment (24), oil palms planted in June 1955 Soil: Ms-series.

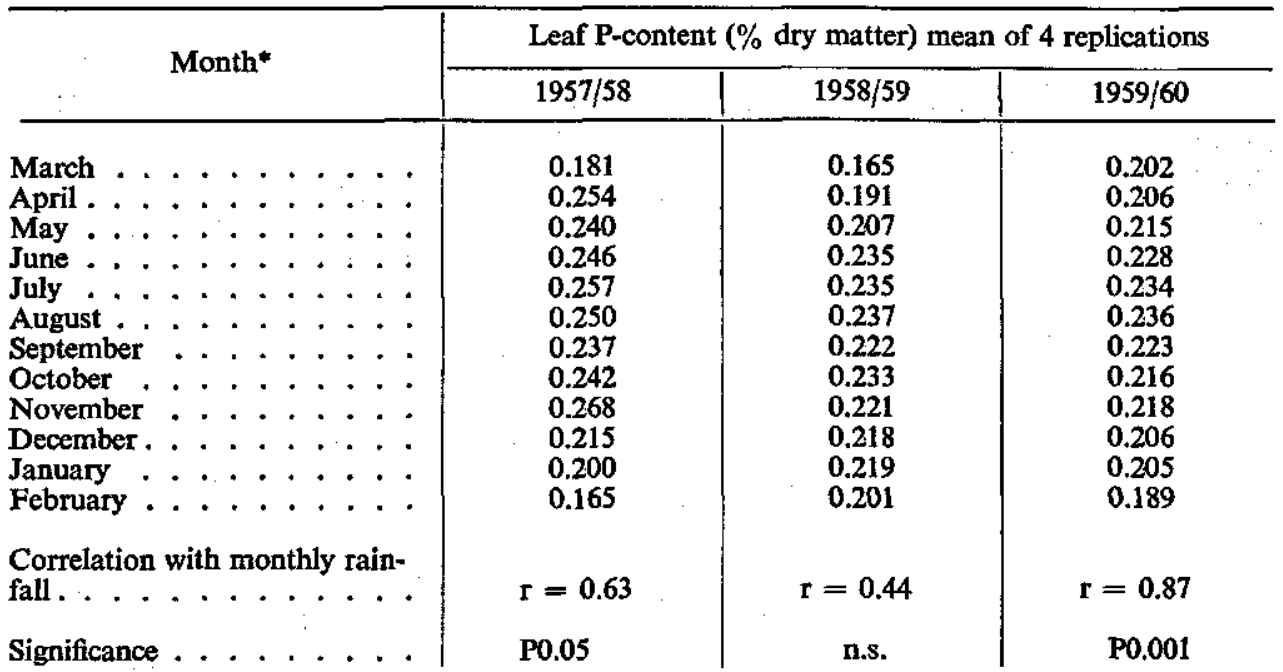

* half annual fertilizer applications in March/April and October respectively. 
The leaf P-contents increased with increasing rainfall, probably owing to increasing soil moisture supply. Hence, the larger the water retaining capacity and the rooting volume of the soil the better the P-supply. With regard to the rooting volume it was interesting to note that seasonal fluctuations in leaf P-contents decreased with increasing age of the palms, suggesting a relationship with the more developed rootsystem of older palms.

Vascular Wilt disease of oil palms is like Panama Disease in bananas caused by a soil inhabiting fungus. It was observed at the site of an old volcanic crater (Vt 1-series) at Kie near Bota (see plate 3) in 1956. Its occurrence has been related to K deficiency and $\mathrm{Mn}$-deficiency (Prendergast, private communication). If the incidence of the disease is indeed induced by nutritional disorders, it would be in line with the results obtained with Panama Disease in bananas if a decreased tolerance of the host could be related to an unbalanced nutrient supply rather than to the deficiency of one specific nutrient alone.

The leaf nutrient contents of oil palms showing symptoms of Vascular Wilt infection and of apparently healthy palms at Bota-Kie were followed monthly during a period of 13 months (table 21). The palms of this area were dressed with NPK compound fertilizers up to 1958 and only since April 1959 with NPKMg compound fertilizers.

TABLE 21. Leaf nutrient contents of oilpalms (\% dry matter) planted at Bota - Kie in 1952 (sample size 25 palms).

\begin{tabular}{|c|c|c|c|c|c|c|c|c|c|c|}
\hline \multirow[t]{2}{*}{ Month } & \multicolumn{2}{|c|}{$\begin{array}{c}\% \mathrm{~N} \\
\text { optimal level } * \\
\text { is } 2.70 \%=100\end{array}$} & \multicolumn{2}{|c|}{$\begin{array}{c}\% \mathbf{P} \\
\text { optimal level } \\
\text { is } 0.23 \%=100\end{array}$} & \multicolumn{2}{|c|}{$\begin{array}{c}\% \mathbf{K} \\
\text { optimal level } \\
\text { is } 1.80 \%=100\end{array}$} & \multicolumn{2}{|c|}{$\begin{array}{c}\% \mathrm{Ca} \\
\text { optimal level } \\
\text { is } 0.5 \%=100\end{array}$} & \multicolumn{2}{|c|}{$\begin{array}{c}\% \mathrm{Mg} \\
\text { optimal level } \\
\text { is } 0.30 \%=100\end{array}$} \\
\hline & $\mathrm{V}^{* *}$ & $\mathrm{H}^{* * *}$ & $\mathrm{~V}$ & $\vec{H}$ & $\mathrm{~V}$ & $\mathbf{H}$ & $\mathrm{V}$ & $\mathrm{H}$ & V & $\mathrm{H}$ \\
\hline pril '59. & 101 & 102 & 94 & 91 & 91 & 89 & 87 & 92 & 78 & 87 \\
\hline & 99 & 11 & 10 & 10 & 97 & 9. & 89 & 89 & & 127 \\
\hline & 99 & 12 & ic & & 93 & 9 & 83 & 76 & 101 & 119 \\
\hline & 99 & 11 & 10 & 11 & 93 & 93 & 94 & 94 & 92 & 119 \\
\hline & 121 & 1 & 100 & 1 & 8 & 9. & 102 & $y$ & 91 & 26 \\
\hline ber & 91 & 11 & 98 & 11 & 8 & 8 & 99 & 9 & 9. & 116 \\
\hline & 87 & 10 & 97 & 10 & 9 & 104 & 85 & 8 & 7 & 99 \\
\hline & 89 & 11 & 97 & 10 & 0 & 89 & 92 & 102 & 7 & 98 \\
\hline & 93 & 10 & 9 & 10 & & 10 & 9 & 85 & 6 & 99 \\
\hline$' 60$ & 104 & 10 & 0 & 9 & & 10 & & & 78 & 99 \\
\hline 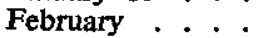 & 98 & 10 & 10 & 9 & & 10 & & 10 & 7 & 103 \\
\hline & 99 & 10 & . & 100 & & 10 & 1 & 11 & 7 & 99 \\
\hline & 99 & 10 & 96 & 93 & 111 & 101 & 145 & 129 & 73 & 97 \\
\hline Iean & 98 & 108 & 98 & 103 & 98 & 97 & 101 & 97 & 82 & 107 \\
\hline $\begin{array}{l}\text { efficient of } \\
\text { riation } \%\end{array}$ & $8.6 \%$ & $2.1 \%$ & $2.8 \%$ & $5.0 \%$ & $9.9 \%$ & $6.7 \%$ & $16.7 \%$ & $13.5 \%$ & $13.0 \%$ & $12.1 \%$ \\
\hline Significance & & & & .02 & & s. & & n.s. & & .01 \\
\hline
\end{tabular}

* cf. (24) and (28).

** $\mathrm{V}=$ palms showing symptoms of Vascular Wilt.

*** $\mathbf{H}=$ apparently healthy palms.

It will be seen from table 21 that the $\mathrm{Ca}$ and $\mathrm{Mg}$ leaf contents varied more than those of $\mathrm{N}, \mathrm{P}$, and to a lesser extent $\mathrm{K}$ of both healthy and diseased palms. Moreover, the $\mathrm{Mg}$-contents of the diseased palms were during almost the entire period of observation well below the level considered to be optimal. This latter result and the striking fact 
that presently Vascular Wilt infection is almost entirely confined to the limited area of deep but leached old volcanic soils at Kie and has not spread to the surrounding very rocky but young volcanic soils would indicate a relationship between the occurrence of the disease and the $\mathrm{Mg}$ supply. For, the fertilizer dressings were unbalanced in respect of $\mathrm{Mg}$ and the $\mathrm{Mg}$ supplying power (cf. table 9) of the unweathered young volcanic soil is larger than of old volcanic soil. It would be incorrect to conclude from this a causal relationship between leaf $\mathrm{Mg}$-content and Vascular Wilt infection. The results reported here and elsewhere rather suggest a relationship between the resistance of the host and a balanced nutrient supply.

\section{E. SOIL-CROP RELATIONSHIPS IN RUBBER}

Two of the Corporation's rubber estates are situated on the eastern slopes of the Cameroon Mountain, one at Meanja the other in the Tiko plain, on marine alluvial soils (Ms-series) mainly, except for a small area at Meanja, which consists of young volcanic soils (Va-series) (see plate 2).

Detailed results of growth and yield responses of rubber trees, growing on marine alluvial soils differing in depth owing to root impeding layers, to $N$, $P$, or $K$ fertilizers and their combinations were summarised by the author and published elsewhere (25). They were similar to those obtained with oil palms and bananas on the same soils (Msseries). Furthermore, it was demonstrated that under the prevailing conditions of soil and climate the adverse effect of root impeding layers on growth and yield was approximately twice as large as the favourable effects that may be obtained from fertilizers.

The adverse effect of shallow soils in dry periods appeared to be twofold: firstly the effect of drought itself on growth and yield and secondly its indirect effect on the tolerance of the trees to wind damage. This latter effect in particular should form a major consideration in the assessment of the suitability of a soil for growing rubber, because the losses sustained from high velocity winds are large, even for wind tolerant clones.

The effect of drought on growth and yield and the tolerance of the trees to wind damage was reduced by $\mathrm{K}$-fertilizer dressings, particularly if applied before the onset of the dry season (25).

Previously it was reported that growth and longevity of bananas allowed a quick and easy appraisal of the quality of a soil. It was found to be extremely useful in cases where abandoned banana land was going to be replanted with other perennial crops. The banana fertilizer trial Pungo No. I (see paragraph C) was replanted with rubber in 1958. The layout and treatments were the same as before when the trial was planted with bananas. Another banana trial, also on marine alluvial soil (Ms-series) and in which the amounts of $\mathrm{N}$ and $\mathrm{K}$ were compared in single (amounts as in Pungo No. I) and double doses was also replanted with rubber in 1958. This experiment No. Mk VI was known to have root impeding layers at variable depth causing large variations in productivity of the replications (table 22 ).

It will be seen from table 22, that soil profile and fertilizing in Pungo trial No. I affected growth to the extent of $6 \%$ and $8 \%$ respectively.

In trial Mk VI these percentage increases in a period covering the dry season mainly, were $17 \%$ and $7 \%$ respectively. These differences in girth, if maintained until maturity, were found to correspond with yield differences in the firsttwo years of production of twice or thrice that amount.

The growth responses obtained in another rubber trial, i.e. at Meanja on marine alluvial soil (Ms-series), were reported elsewhere (25). It will be seen from table $23 \mathrm{~A}$, 
TABLE 22. Girth increase of rubber in $\mathrm{cm}$.

Pungo No. I: period July 1958-July 1960.

Muyuka No. VI: period December 1959-July 1960.

\begin{tabular}{|c|c|c|c|}
\hline \multicolumn{2}{|c|}{ Pungo No. I } & \multicolumn{2}{|c|}{ Muyuka No. VI } \\
\hline Treatment & $\begin{array}{l}\text { girth increase mean } \\
\text { of } 3 \text { replications }\end{array}$ & Treatment & $\begin{array}{l}\text { girth increase mean } \\
\text { of } 6 \text { replications }\end{array}$ \\
\hline 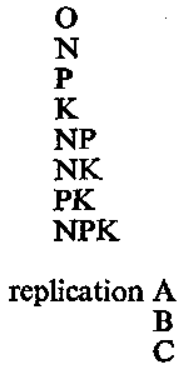 & $\begin{array}{r}10.1 \\
10.0 \\
10.3 \\
10.3 \\
10.2 \\
10.0 \\
9.9 \\
10.9 \\
\\
10.6 \\
9.9 \\
10.0\end{array}$ & $\begin{array}{l}\text { 1N. 1P. 1K } \\
\text { 1N. 1P. 2K } \\
\text { 2N. 1P. 1K } \\
\text { 2N. 1P. 2K } \\
\text { replication A } \\
\text { B } \\
\text { C } \\
\text { D } \\
\text { E } \\
\text { F }\end{array}$ & $\begin{array}{lr}6.1 & (=100) \\
6.6 & (107) \\
6.4 & (104) \\
6.5 & (106) \\
& \\
6.1 & (106) \\
5.8 & (=100) \\
6.5 & (112) \\
6.5 & (112) \\
6.8 & (117) \\
6.8 & (117)\end{array}$ \\
\hline
\end{tabular}

that the yields obtained in the Meanja trial were high and were favourably affected by fertilizing. The specific effects of $\mathrm{N}$ and $\mathrm{K}$ fertilizers on tolerance of the trees to windstorms were clearly demonstrated in 1959, a year of serious winddamage. In 1958 and 1960 todate, marked yield responses to $\mathrm{N}$ dressings were obtained but not in 1959 . The effect of $\mathrm{K}$ dressings on windtolerance was demonstrated by the yield reponses to $\mathrm{K}$ in 1959. Furthermore, the effect of $\mathrm{N}$ in $1960 / 61$ increased from $7 \%$ in the first cycle (end of dry season) to $28 \%$ in the fourth cycle, covering August and part of September, i.e. the wettest and coolest period of the year. An opposite trend was observed for $\mathrm{K}$. As found with bananas and oil palms, the interactions between $N$ and $K$, and $P$ and $K$ were negative and positive respectively, NPK often being the outstanding treatment. The latter, however, did not come up to expectations, as will be seen when comparing the sum of the effect of dressings of $N$ alone plus $K$ alone plus $P$ alone with the effect of treatment NPK in 1960/61 todate. The sum of the former amounted to total percentage increases (cf table $23 \mathrm{~A}$ ) of $47 \%$ (i.e. $7+14+26$ ), $74 \%, 65 \%$ and $68 \%$ for the 1 st, 2nd, 3rd and 4th cycle 1960/61 respectively, against the actually obtained increases obtained from treatment NPK of $9 \%, 15 \%, 15 \%$ and $22 \%$ respectively. This might be partly explained as follows: firstly the ratio between the three main nutrients in treatment NPK was the same in dressings applied before and after the rains (cf. 25) and secondly the availability of the nutrients in the three fertilizers used, i.e. sulphate of ammonia, rockphosphate and muriate of potash, is not the same. As a result the nutrients will not become available at the same time, and more important at the time they are needed most by the plants. In the previous paragraphs it was shown that $\mathrm{K}$ was needed most during the dry season, $N$ during the rainy season, and that the availability of $P$ was related to soil moisture supply (cf. table 20 ).

As regards $N$, the studies carried out by $\operatorname{BrRCH}(4,5,6)$ in East Africa on the effect of different periods of dryness on nitrification in soils are of great interest. This author demonstrated that the longer a soil remains in an air-dry state, the greater the amounts of carbon and nitrogen mineralised on moistening it.

Periods of alternate drying and wetting occur at the beginning but particularly at the end of the dry season. It provided another approach to explain the lack of an effect or even an adverse effect of $\mathrm{N}$-fertilizers applied in the dry half of the year.

Finally, it will be seen from table $23 \mathrm{~B}$ that the effect of profile differences occurring 


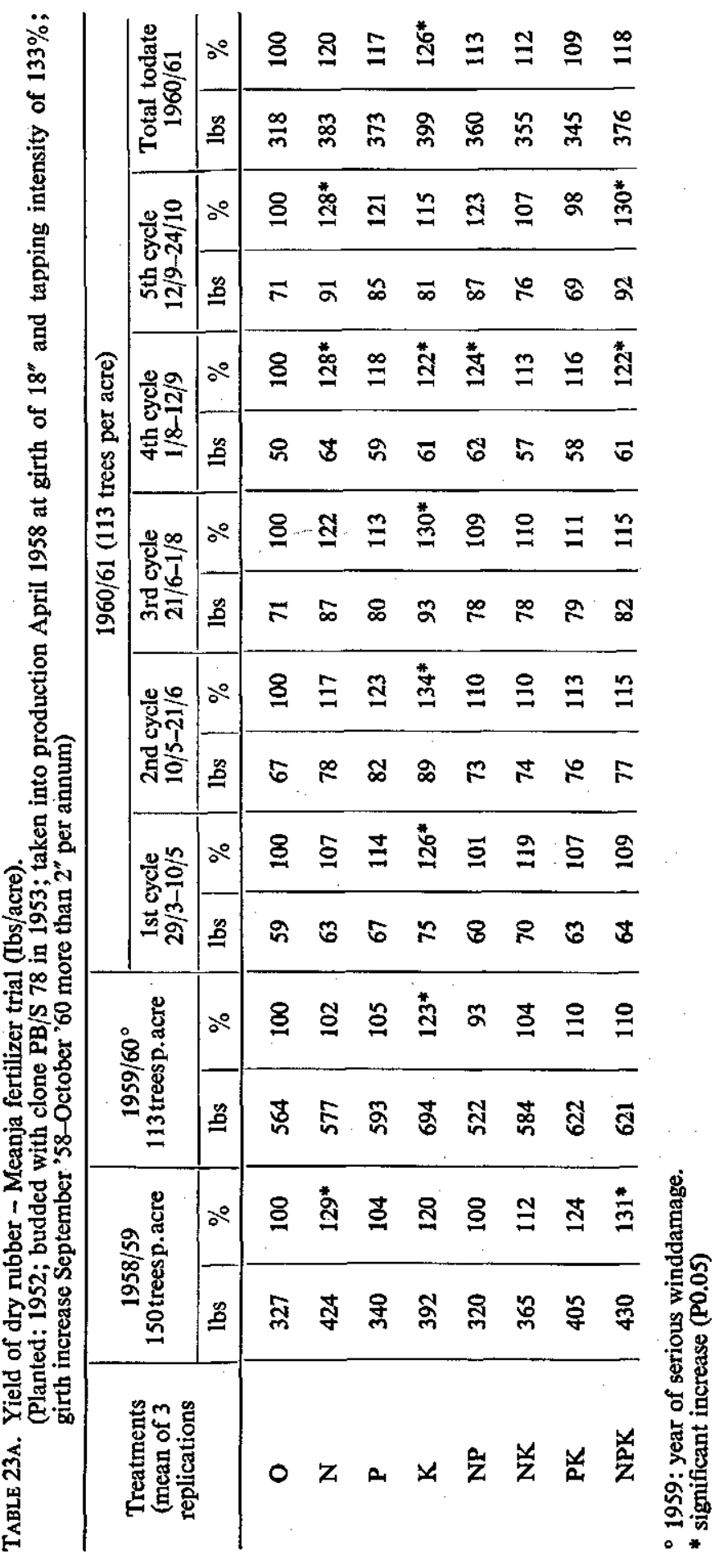


TABLE 23B. (cf. table 23A.)

\begin{tabular}{|c|c|c|c|c|c|}
\hline \multirow{2}{*}{ Replacations } & \multirow{2}{*}{ Profile description } & \multicolumn{2}{|c|}{$1958 / 59$} & \multicolumn{2}{|c|}{$1959 / 60^{*}$} \\
\hline & & lbs & $\%$ & lbs & $\%$ \\
\hline $\begin{array}{r}\quad 0-15 \mathrm{~cm} \\
15-100 \mathrm{~cm} \\
110-240 \mathrm{~cm}\end{array}$ & $\begin{array}{l}\text { loamy sand } \\
\text { very sandy clay } \\
\text { not indurated coricretional layer } \\
\text { mixed with sandy clay; below } \\
120 \mathrm{~cm} \text { mottling }\end{array}$ & 365 & 100 & 562 & 100 \\
\hline B & transitional between $\mathrm{A}$ and $\mathrm{C}$ & 370 & 101 & 611 & 109 \\
\hline $\begin{array}{l}0-10 \mathrm{~cm} \\
10-190 \mathrm{~cm} \\
190-240 \mathrm{~cm} \\
\text { at } 240 \mathrm{~cm}\end{array}$ & $\begin{array}{l}\text { sandy loam } \\
\text { sandy clay } \\
- \text { do - mixed with coarse sand } \\
\text { few concretions }\end{array}$ & 394 & 108 & 619 & 110 \\
\hline
\end{tabular}

* 1959: year of serious winddamage.

at a depth of $110 \mathrm{~cm}$ amounted to yield differences of $8 \%$ in $1958 / 59$ and $10 \%$ in $1959 / 60$. The fact that such minor differences in soil could affect the yields appreciably, demonstrated once more how finely drawn the balance is between yield and soil characteristics in a climate where a pronounced dry season is followed by severe windstorms and a rainy season with little sunshine.

\section{F. SOIL-CROP RELATIONSHIPS IN COCOA}

The Corporation's only cocoa estate is situated at Tombel, some 45 miles northeast of Ekona, at an altitude of between $1000^{\prime}$ and $1500^{\prime}$ above M.S.L. The area is part of the Kupe Mountain range, and is well away from the Cameroon Mountain proper. The soils (cf. table 10) consist of young volcanic ash deposits, comparable with but lighter in texture and probably younger than the mudflow deposited soils down below Buea.

A new cocoa estate is being developed in the Tiko plain, mainly situated on soils of the Mva-series around Tiko, but also partly on soils of the Ms-series.

In order to assess the growth of cocoa plants originating from three different mother trees, selected at Tombel, on deep marine alluvial soil (Ms-series), a NPK-fertilizer trial with 6 replications was laid down at Mondoni. It was planted in June 1958, with seedlings raised in nurseries in January 1958. At the end of 1958, i.e. when the plots had received the two half annual fertilizer applications of 1958, but before the first half annual application of 1959 , the number of trees, which had formed fans, was recorded (table 24). The soil throughout the experimental area was carefully surveyed on its uniformity. Rooting depth was more than $4 \mathrm{ft}$. in all the replications, except in replications $\mathrm{C}$ and $\mathrm{E}$ where it was less. The different behaviour of the progenies will not be discussed.

It will be seen from table 24 that the distribution of $\mathrm{C} 2 / 12$ seedlings with fans was related to the fertilizer treatments. The percentage trees with fans was $25 \%$ for control against $56 \%$ for NPK. Tested with the chisquare test, it appeared that the non-fertilized trees had a significantly lower number of fans than the average for the experiment, while treatment NPK had a significantly higher incidence of trees with fans. In other words, fertilizing with either $\mathrm{N}, \mathrm{P}$ or $\mathrm{K}$ or their combinations improved the growth, treatment NPK being outstanding. These results were in line with those obtained in 
TABLE 24. Trinitario cocoa fertilizer trial: Mondoni-Tiko soil: $\quad$ Ms 7-series.

altitude: $70^{\prime}$ above M.S.L.

\begin{tabular}{|c|c|c|c|c|c|c|c|}
\hline & $\begin{array}{r}\text { Treatme } \\
\text { (mean of replicatic }\end{array}$ & ts & $\begin{array}{l}\% \text { trees with fans } \\
\text { (progenies from pe }\end{array}$ & $\begin{array}{l}\text { son } 16 \\
\text { arent } t\end{array}$ & .195 & & \\
\hline & $\begin{array}{l}\mathrm{o} \\
\mathbf{N} \\
\mathbf{P} \\
\mathbf{K} \\
\mathbf{N P} \\
\mathrm{NK} \\
\mathrm{PK} \\
\mathrm{NPK} \\
\mathrm{Mean}\end{array}$ & & $\begin{array}{r}25 \\
38 \\
48 \\
33 \\
42 \\
50 \\
35 \\
56 \\
41\end{array}$ & & & & \\
\hline & & & & & an gir & per $t$ & \\
\hline Replications & rooting depth & $\begin{array}{l}\% \text { trees wi } \\
\text { (progenies f }\end{array}$ & $\begin{array}{l}\text { fans on } 24.3 .1959 \\
\text { m parent tree } \mathrm{B} 1 / 4)\end{array}$ & Janua & 1960 & Apri & 1960 \\
\hline & & & & $\mathrm{cm}$ & $\%$ & $\mathrm{~cm}$ & $\%$ \\
\hline $\begin{array}{l}\mathrm{A} \\
\mathbf{C} \\
\mathrm{E}\end{array}$ & $\begin{array}{l}\text { more than } 120 \mathrm{~cm} \\
80-100 \mathrm{~cm} \\
100-120 \mathrm{~cm}\end{array}$ & & $\begin{array}{l}44 \\
38 \\
40\end{array}$ & $\begin{array}{l}13.3 \\
12.4 \\
13.2\end{array}$ & $\begin{array}{l}107 \\
100 \\
106\end{array}$ & $\begin{array}{l}15.2 \\
13.7 \\
14.6\end{array}$ & $\begin{array}{l}111 \\
100 \\
107\end{array}$ \\
\hline
\end{tabular}

* Significant chi- square at P0.05.

bananas, oil palms and rubber, viz. that on marine alluvial soils (Ms-series) fertilizer applications, particularly when they are balanced, will improve growth.

The results also showed that profile differences occurring at a depth of $3 \mathrm{ft}$. affected growth of cocoa to the extent of a $10 \%$ difference in girth. The latter is estimated to correspond with yield differences of twice or thrice that amount. Furthermore, the results to date indicated that cocoa can be grown very successfully on these soils, provided they are deep and probably well fertilized.

Several pods were reaped in 1959 , whilst in 1960 , in the third year after planting, a yield of $200 \mathrm{lbs}$ dry cocoa per acre is expected, varying between $75 \mathrm{lbs}$ and $300 \mathrm{lbs}$ per acre for the lower and higher yielding progenies respectively.

The most serious disease of cocoa in the Southern Cameroons at the present time is Black Pod Disease, Phytophthora palmivora (BUTLER) BUTLER. If no control measures are applied three quarters of the potential yield will be lost to the disease under Tombel conditions. Owing to the many factors influencing the disease pattern, the assessment of disease control was found to be a complex problem (29). Moreover, spraying experiments often suffer from unknown sources of variation, or to quote SCHNEDECOR (44): "For some unknown reason ("fruit") injuries under identical experimental treatments differ significantly. Hence, it is impossible to compare sprays on single trees, because a difference in percentages of injured fruit might be attributable either to the treatments or to unknown sources of variation."

In order to assess the effect of fertilizer treatments on Black Pod incidence in an NPK experiment at Tombel, the results of which served as the basis for an article on the assessment of Black Pod disease by HASSELO and PRICE (29), SANDERS (43) worked out yield and Black Pod data of each of the 256 trees, contained by 8 treatments of 16 trees each in two replications for 1955/56, 1956/57 and 1957/58.

Owing to the fact that yield and Black Pod incidence are correlated quantities, the 
plot (treatment) means for disease incidence had to be adjusted for the mean yield of each of the replications in any one year. As a result the adjusted plot means within one replication in one particular year could be compared, but not those between diferent years and replications. In order to be able to compare the disease incidence as affected by fertilizer treatments, the adjusted treatment means were given a rank number, No. 1 having the lowest incidence increasing to No. 8, having the highest incidence (table 25).

TABle 25. Level (1 lowest -8 highest) of Black Pod incidence.

Tombel NPK - fertilizer trial.

\begin{tabular}{|c|c|c|c|c|c|c|c|c|}
\hline \multirow{3}{*}{ Treatment } & \multicolumn{6}{|c|}{ Level of infection } & \multirow{3}{*}{ Total } & \multirow{3}{*}{$\begin{array}{l}\text { Main effects and } \\
\text { interactions }\end{array}$} \\
\hline & \multicolumn{3}{|c|}{ Replication A } & \multicolumn{3}{|c|}{ Replication B } & & \\
\hline & $1955 / 56$ & $1956 / 57$ & $1957 / 58$ & $1955 / 56$ & $1956 / 57$ & $1957 / 58$ & & \\
\hline $\begin{array}{l}\mathbf{O} \\
\mathbf{N} \\
\mathbf{P} \\
\mathrm{K} \\
\mathrm{NP} \\
\mathrm{NK} \\
\mathbf{P K} \\
\mathrm{NPK}\end{array}$ & $\begin{array}{l}6 \\
3 \\
8 \\
2 \\
7 \\
1 \\
5 \\
4\end{array}$ & $\begin{array}{l}5 \\
1 \\
6 \\
8 \\
2 \\
7 \\
4 \\
3\end{array}$ & $\begin{array}{l}6 \\
1 \\
7 \\
8 \\
2 \\
5 \\
4 \\
3\end{array}$ & $\begin{array}{l}1 \\
3 \\
8 \\
2 \\
7 \\
6 \\
4 \\
5\end{array}$ & $\begin{array}{l}5 \\
3 \\
8 \\
4 \\
7 \\
6 \\
2 \\
1\end{array}$ & $\begin{array}{l}1 \\
6 \\
7 \\
4 \\
8 \\
5 \\
2 \\
3\end{array}$ & $\begin{array}{l}24 \\
17 \\
44^{\star} \\
28 \\
33 \\
30 \\
21 \\
19\end{array}$ & $\begin{array}{r}-18 \\
+18 \\
-8 \\
-20 \\
+18 \\
-54^{*} \\
0\end{array}$ \\
\hline
\end{tabular}

* Significant at P0.05.

Although the results of table 25 have to be viewed with some caution, they indicate a similar trend as repeatedly observed for the crops discussed so far. The adverse effect of single $P$ dressings is to a large extent offset by the addition of $K$ (cf. treatment PK), owing to a large negative interaction between these two nutrients.

\section{G. SOIL-CROP RELATIONSHIPS IN TEA}

Little experience has been gained yet as regards the suitability of young volcanic soils (Va-series) for growing tea in the Tole estate near Buea (27).

Tole tea estate is situated approximately 2 miles south-southeast of Buea at an altitude of between $2200^{\prime}$ and $2500^{\prime}$ above M.S.L. Growth of tea is excellent provided there are no root impeding layers at shallow depth.

An NPK fertilizer trial with eight replications was laid out in an area planted in 1959. The first application of fertilizers was made in November 1959, the second in May 1960. In June and October 1960 the diameter of approximately 930 plants was measured at $3^{\prime \prime}$ above the ground (table 26).

It will be seen from the results of table 26 that the effect of $K$ and $N$ dressings was outstanding in the dry and wet half of the year respectively. This is in line with the general trend of crop responses to fertilizer applications discussed in the previous paragraphs.

H. SUMmary: MiNeral DEFICIENCIES OF THE SOILS OF THE LOWER SLOPES OF THE Cameroon Mountain

The results, obtained from fertilizer effects on growth and yield of and disease incidence in perennial crops grown on the lower eastern slopes of the Cameroon Mountain, could be summarized as follows: $K$ is the main deficiency, in particular during 
TABLE 26. Diameter of tea plants - NPK fertilizer trial.

area: Tole tea estate

soil: $\quad$ Young volcanic soil (Va-series)

altitude: $2200^{\prime}$ above M.S.L.

$\mathrm{pH}\left(\mathrm{H}_{2} \mathrm{O}\right): 6.0-6.5$

\begin{tabular}{|c|c|c|c|c|c|c|c|}
\hline \multirow{3}{*}{ Treatment } & \multirow{3}{*}{ No. of plants } & \multicolumn{4}{|c|}{ Mean diameter per plant } & \multirow{2}{*}{\multicolumn{2}{|c|}{$\begin{array}{c}\text { Increase } \\
\text { May-October } 1960\end{array}$}} \\
\hline & & \multicolumn{2}{|c|}{ May 1960} & \multicolumn{2}{|c|}{ October 1960} & & \\
\hline & & $\mathrm{mm}$ & $\%$ & $\mathrm{~mm}$ & $\%$ & $\mathrm{~mm}$ & $\%$ \\
\hline $\begin{array}{l}\mathbf{O} \\
\mathbf{N} \\
\mathbf{P} \\
\mathbf{K} \\
\mathbf{N P} \\
\mathbf{N K} \\
\mathbf{P K} \\
\mathrm{NPK}\end{array}$ & $\begin{array}{l}115 \\
117 \\
119 \\
118 \\
117 \\
117 \\
116 \\
113\end{array}$ & $\begin{array}{l}6.2 \\
6.6 \\
6.4 \\
7.0^{*} \\
6.5 \\
7.3^{* *} \\
6.7 \\
6.9^{*}\end{array}$ & $\begin{array}{l}100 \\
106 \\
102 \\
112 \\
103 \\
116 \\
108 \\
110\end{array}$ & $\begin{array}{l}9.5 \\
10.6 \\
10.3 \\
10.5 \\
11.0^{*} \\
11.3^{* *} \\
10.0 \\
10.7^{*}\end{array}$ & $\begin{array}{l}100 \\
112 \\
108 \\
111 \\
116 \\
119 \\
105 \\
113\end{array}$ & $\begin{array}{l}3.3 \\
4.0 \\
3.9 \\
3.5 \\
4.5^{*} \\
4.0 \\
3.3 \\
3.8\end{array}$ & $\begin{array}{l}100 \\
121 \\
118 \\
106 \\
136 \\
121 \\
100 \\
115\end{array}$ \\
\hline \multicolumn{2}{|c|}{ Significant main effect } & \multicolumn{2}{|c|}{$\underset{\text { (positive) }}{\mathbf{K}^{* *}}$} & \multicolumn{2}{|c|}{$\underset{\text { (positive) }}{\mathbf{N}^{*}}$} & \multicolumn{2}{|c|}{$\begin{array}{c}\mathrm{N}^{*} \\
\text { (positive) }\end{array}$} \\
\hline
\end{tabular}

* significant (difference) at P0.05

** significant (difference) at P0.01

the dry season and on young volcanic soils. The next important deficiency is $\mathrm{N}$, particularly on marine alluvial soils (Ms-series) and during the rainy season. The effect of fertilizer applications of both $\mathrm{N}$ and $\mathrm{K}$ in a fixed ratio was frequently found to be inferior to that of the sum of effects, obtained from dressings of $\mathrm{N}$ alone and $\mathrm{K}$ alone, owing to a negative interaction between them. P-fertilizers applied alone commonly had no effect and sometimes even an adverse effect on growth and yield of the crop, particularly in the rainy season. They influenced the yields and tolerance of the plants to diseases favourably, when applied in combination with $\mathrm{K}$ or NK probably owing to a large positive interaction between $P$ and $K$.

In the light of these results, it would appear that $\mathrm{N}, \mathrm{P}$ and $\mathrm{K}$ fertilizers are best applied at the same time and in a form that they become available at the same time, and at ratios which are adepted to the different requirements of the plants in different seasons and to the seasonal variations in nutrient availability in the soil. In plantation crops, this is easier and better achieved with compounded NPK-fertilizers, than with separate applications of straight $\mathrm{N}, \mathrm{P}$ an $\mathrm{K}$-fertilizers, and may result in a much greater efficiency of the applied nutrients.

Next in the range of possible deficiencies, i.e. after $\mathrm{K}, \mathrm{N}$ and $\mathrm{P}$, came $\mathrm{Mg}$, particularly on non-volcanic soils, but also on rocky and/or light volcanic soils, in oil palms and probably during the rainy season. The occurrence of severe $\mathrm{Mg}$-deficiency in high yielding banana areas fertilized with large NPK-dressings in the Ivory Coast (13) pointed in the same direction. A favourable effect from lime applications could so far not be demonstrated.

In the foregoing pages, it was seen that responses to applications of nutrients or the appearance of a nutrient deficiency was often influenced by interactions between the nutrients themselves in combination with seasonal and soil profile variations. It is, therefore, necessary for a better understanding of cause and effect to distinguish between absolute and relative soil nutrient deficiencies and profile and seasonally induced deficiencies, which may be further complicated by physiological disorders, resulting 
from changes in nutrient requirements of plants at different stages of growth (cf. 24, 25: the change from vegetative to reproductive stage in oil palms and rubber).

The role of trace elements in the nutrition of the crops under consideration has not been studied. It may be expected, however, that, with the introduction of routine fertilizer applications, their role will become increasingly important. This may also be inferred from the common occurrence of zinc deficiency symptoms in citrus trees, especially orange and grapefruit trees, and the occasional observation of symptoms of boron deficiency in oil palms (cf. 20).

\section{SAMENVATTING}

Zuid Kameroen is een Brits voogdij gebied, gelegen tussen Nigeria in het Westen en de republiek Kameroen in het Oosten.

De bananen-, oliepalm-, rubber-, cacao- en theeplantages, die vóór de tweede wereldoorlog toebehoorden aan Duitse eigenaren, werden in 1947 in beheer gegeven aan de daartoe opgerichte Cameroons Development Corporation (hoofdstuk 1).

Het merendeel van deze plantages is gelegen op de oostelijke hellingen van de Kameroen Berg. De kartering van de gronden gelegen in het gebied beneden de hoogtelijn van 100 meter werd begonnen in 1957 en uitgevoerd op een schaal van $1: 25.000$. De hierbij verkregen gegevens werden met behulp van stereoscopische interpretatie van luchtfoto's verzameld in kaarten met een schaal van $1: 6500$ of $1: 13.000$ (de schaal van de luchtfoto's) (hoofdstuk 4).

De hierbij opgedane ervaring, aangevuld met een gedetailleerde physiografische studie (hoofdstuk 2), werd vergeleken met de door de Fransen (NICKLès, 36) verzamelde kennis in het aangrenzende gebied in de republiek Kameroen. Dit leidde tot het vermoeden, dat het gebied gelegen beneden de 100 meter hoogtelijn van alluviale oorsprong en kwartaire ouderdom is. Om deze hypothese te toetsen werden de lengteprofielen van de rivieren (grafieken 2 en 3 , hoofdstuk 4) gemeten en onderling vergeleken. Daarbij bleek, dat het grootste deel van dit gebied inderdaad overdekt was geworden met marien alluvium in het kwartair.

Overblijfselen van het pre-mariene landschap werden slechts daar aangetroffen, waar weinig of geen materiaal werd afgezet op het precambrische landschap, of waar heuvels van tertiair-vulkanische oorsprong de nivellerende werking van de zee weerstonden.

De nog niet gekarteerde gebieden, gelegen beneden de 100 meter hoogtelijn ten zuiden en ten westen van de Kameroen Berg, bleken bij bestudering van de topografische kaarten dezelfde mariene kenmerken te bezitten. Een uitzondering vormden die gebieden, waar vulkanische stromen van een meer recente, namelijk post-mariene datum. doordrongen tot beneden de 100 meter hoogtelijn en de mariene afzettingen overdekten.

De kennis van het bestaan, de oorsprong en ouderdom van de mariene afzettingen maakte het mogelijk de relatieve ouderdom van de vulkanische afzettingen, gelegen boven de 100 meter hoogtelijn (hoofdstuk 3), te bepalen. Door vervolgens de landschappen, gelegen boven de 100 meter hoogtelijn, te bestuderen met behulp van de luchtfoto's, aangevuld met waarnemingen in het veld van van te voren uitgezochte sleutelgebieden, werd bereikt, dat een physiografische verkenningskaart met een schaal van $1: 100.000$ kon worden gemaakt.

In hoofdstuk 5 tenslotte werd het effect behandeld van de verschillende oorsprong en ouderdom van het moedermateriaal en van de verschillen in profieleigenschappen van de jong- en oud-vulkanische en de mariene gronden op hun geschiktheid voor de plantageverbouw van de overjarige tropische gewassen: bananen, oliepalm, rubber, cacao en thee. 


\section{REFERENCES}

1. Anon. - A pilot's primer of West African weather - Meteorological Office - Air Ministry, M. $O$. 469 - (A. P. 3092) - 1944.

2. Annual Reports of the Cameroons Development Corporation for the years 1947-1958.

3. BIESEN, J. van: Annual and monthly rainfall maps - Southern Cameroons, C. D. C. Research Ekona 1957. Annual and monthly sunshine maps Southern Cameroons, C. D. C. Research Ekona, 1960.

4. Birch, H. F.: The effect of soil drying on humus decomposition and nitrogen availability. Plant and Soil, 10, 9, 1958.

5. BrRCH, H. F.: Further observations on humus decomposition and nitrification. Plant and Soil, 11, 262-286, 1959.

6. BrRCH, H. F.: Nitrification in soils after different periods of dryness. Plant and Soil, 12, 81-96, 1960.

7. BREDAS, J. and Scuvie, L.: Aperçu des influences climatiques sur les cycles de production du palmier à huile. Oléagineux, 15, 4, 1960, 211-225.

8. Broermans, A. F. M.: Growth, flowering and yield of the oil palm in Nigeria. J. W. Afric. Inst. for Oil Palm Res., 2, 7, 187-219, 1957.

9. BuTLER, A. F.: Fertilizer experiments with the Gros Michel banana. Trop. Agriculture, Trin., 37, $1,31-50,1960$.

10. Cameroons under United Kingdom Administration. Report for the year 1956. Her Majesty's Stationery Office, London, 1957. Colonial No. 334.

11. Champion, J., Dugain, F., Maignien, R., and Dommergues, Y.: Les sols de bananeraies et leur améloration en Guinée. Fruits, 13, 9-10, 415-462, 1958.

12. Charter, C. F.: The aims and objects of tropical soil surveys. Soils and Fertilizers, 20, 3, 127$128,1957$.

13. Dabin, B. and Leneuf, N.: Les sols de bananeraies de la Côte d'Tyoire. Fruits, 15, No. 1, 3-28, No. 2, 77-89, No. 3 117-129, 1960.

14. Dugain, F.: Etude sur la fertilité des sols de la plaine bananière du Cameroun. Fruit, 15, 4, 153-170, 1960.

15. Edelman, C. H.: Fragmenten van het college „Bodemkunde van Nederlands-Indië”. Deel I, Asgronden. Publicatie No. 5, Centrale Commissie voor Wageningse studenten, 1946.

16. Edelman, C. H.: C. D. C. Memorandum, 1958.

17. Edelman, C. H. and HasseLo, H. N.: Technical report on observations made on soils in M'bonge, Mukonje, Ekona, Idenau and Tiko. C. D. C. Memorandum, 1954.

18. EUK, J. J. VAN DER: Reconnaissance soil survey in Northern Surinam - Thesis - Wageningen, 1957.

19. Es, F. W. J. VAN: Photoanalytical map Cameroon Mountain, scale 1:100,000. No field control, Delft, January, 1957.

20. FERWERDA, J. D.: Questions relevant to replanting in oil palm cultivation. Thesis (Wageningen) 1955.

21. GÈze, B.: Géographie physique et Géologie du Cameroun occidental, Memoires Muséum, Nouvelle série, XVII, 1943.

22. Hasselo, H. N.: Earthing-up of Gros Michel bananas. Trop. Agric. (Trinidad), Vol. 34, 1, 1957.

23. Hasselo, H. N.: Private memorandum, C. D. C. 1957.

24. HASSELO, H. N.: Fertilizing of young oil palms in the Cameroons. Plant and Soil, 11, 2, 113-130, 1959.

25. Hasselo, H. N.: Fertilizing of young rubber in the Cameroons. Neth. J. Agr. Science, 8, 3, 165$179,1960$.

26. Hasselo, H. N.: Premature yellowing of Lacatan bananas. Trop. Agric. (Trinidad), 38, 1, 1961.

27. HASSELO, H. N. and BRzESOWSKY, W. J.: Results from a tea fertilizer experiment on young volcanic soils at Tole. C. D. C. Memorandum, 1960.

28. Hasselo, H. N., BrZesowsky, W. J., Biesen, J. vaN, EFITE, J.: Unpublished C. D. C. memoranda 1957-1960.

29. Hasselo, H. N. and Price, D.: The assessment of Black Pod disease control by mistblowing. Trop. Agric. (Trinidad), 1961 (in press).

30. Hasselo, H. N., Swalarick, J. T.: The eruption of the Cameroon Mountain in 1959. Observations on the lava flow and its initial flora. J. West African Sci. Association (in press) 1960.

31. HASSERT, K.: Mitteilungen aus den deutschen Schutzgebieten, Band 24, 1911.

32. Kitagishi, K., Mryasato, S. and OKITA, T.: Response of pasture crops to potassium on volcanic ash soil. J. Sci. Soil Tokyo, 30, 5, 1959.

33. KrenKel, E.: Geologie Afrikas, Band 2, 1928. 
34. LOWE, J. W.: Private memorandum, C. D. C., 1960.

35. MOHR, E. C. J. and BAREN, F. A. van: Tropical Soils. A critical study of soil genesis as related to climate, rock and vegetation. pp. 343-344, 1954.

36. Nickzès, M.: Carte géologique de l'A. E. F. et du Cameroun - Paris, 1952.

37. PèLEGRIN, P.: L'utilisation des engrais en culture bananière. Fruits, 8, 9, 1953,

38. Price, D.: Leaf Spot Disease of the Banana, Mycosphaerella musicola Leach, and its control. M. Sc. Dissertation, London University, July 1958.

39. Price, D.: Clinate and control of banana leaf spot. Span, 3, 3, 122-125, 1960.

40. Price, D.: The effects of several spray regimes on banana fruit weights. Trop. Agriculture, (Trinidad), 37, 4, 325-328, 1960.

41. RISBETH, J.: Fusarium wilt of bananas in Jamaica. II Some aspects of host - parasite relationships. Aun. Bot. Lond., 21, 215-245, 1957.

42. SANDERS, L. A.: Effect of marketability of banana fruit on shipped yields per acre. Private memorandum, C. D. C., 1956.

43. SANDERS, L. A.: Private communication, 1960.

44. SCHNEDECOR, G. W.: Statistical methods, 4th edition. The Iowa state college press, (p. 200, example 9.11), 1946.

45. Schurfelen, A. C. and Middelburg, H. A.: Ionic exchange interrelationships in soils and crops. 1. Ionic selectivity in soils. Neth. J. Agri. Sci., 1, 2, 1953.

46. Sieffermann, G.: First determinations of clay minerals in Cameroon soils. Third Interafrican Soils Conference, Soils III (59), 77, Dalaba, November 1959.

47. Simmonds, N. W.: Bananas. Tropical agriculture series. 1959.

48. Sparnaais, L. D.: The analysis of bunch production in the oil palm. J. W. Afric. Inst. for Oil Palm Res., 3, 10, 109-181, 1960.

49. The Nigeria Handbook, published by the Crown Agents for the Colonies, London, 1953.

50. VINE, H.: Notes on the Main Types of Nigerian Soils. Special Bulletin No. 5 Agric. Department, Nigeria, 1953.

51. ZuLER, R.: Etude de quelques facteurs agissant sur la teneur en coprah des noix de coco. Oléagineux, 15, 2 73-81, 1960. 


\section{SOUTHERN CAMEROONS}

\section{PHYSIOGRAPHIC RECONNAISSANCE MAP}

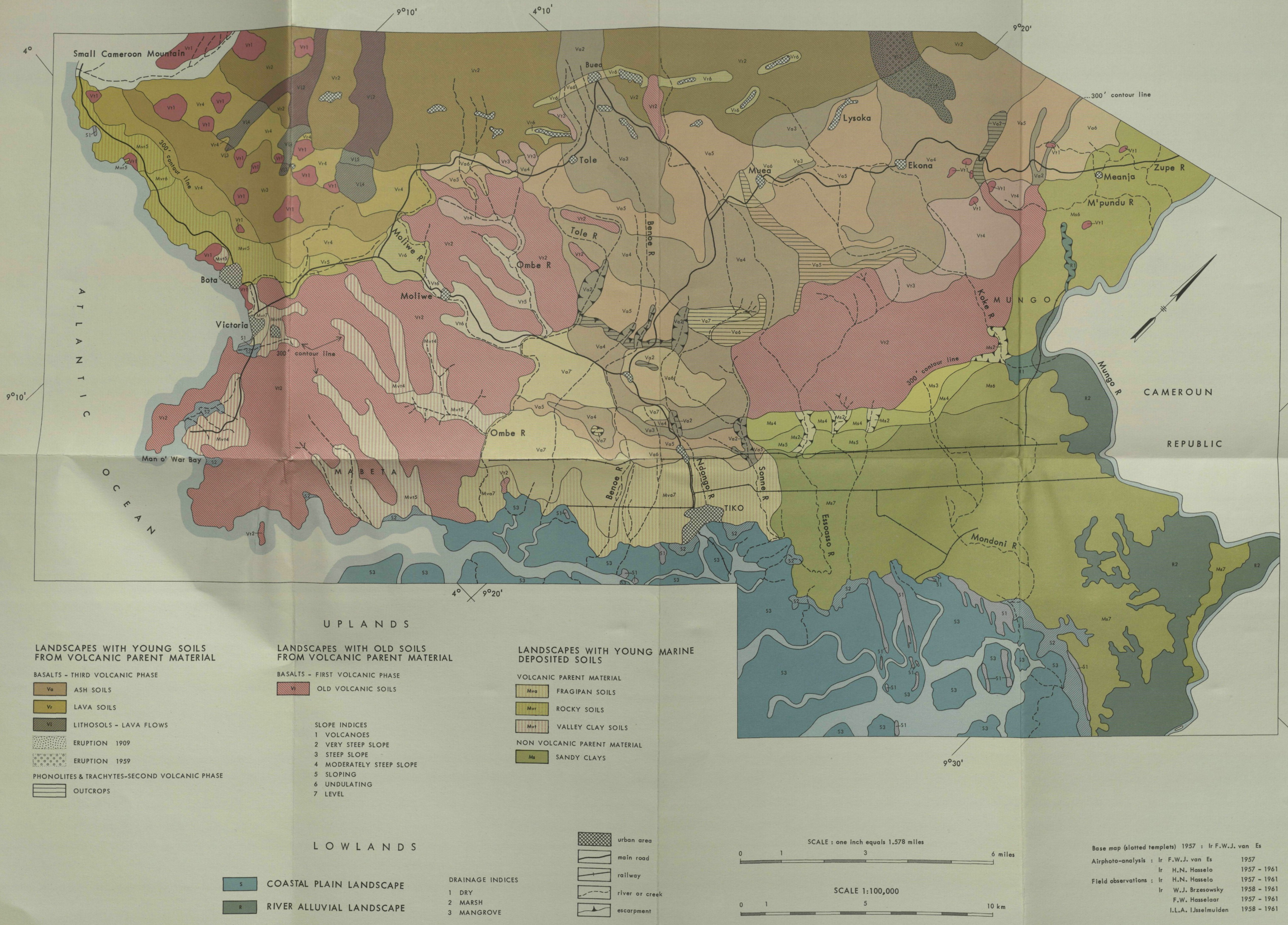

